University of Louisville

ThinkIR: The University of Louisville's Institutional Repository

Electronic Theses and Dissertations

$8-2020$

\title{
Radical renewal, the sisters of Loretto, Nouvelle Theologie, and the second vatican council.
}

\author{
Carol Bolton Easterly \\ University of Louisville
}

Follow this and additional works at: https://ir.library.louisville.edu/etd

Part of the History of Religion Commons, Intellectual History Commons, United States History

Commons, and the Women's History Commons

\section{Recommended Citation}

Easterly, Carol Bolton, "Radical renewal, the sisters of Loretto, Nouvelle Theologie, and the second vatican council." (2020). Electronic Theses and Dissertations. Paper 3514.

https://doi.org/10.18297/etd/3514

This Master's Thesis is brought to you for free and open access by ThinkIR: The University of Louisville's Institutional Repository. It has been accepted for inclusion in Electronic Theses and Dissertations by an authorized administrator of ThinkIR: The University of Louisville's Institutional Repository. This title appears here courtesy of the author, who has retained all other copyrights. For more information, please contact thinkir@louisville.edu. 


\title{
RADICAL RENEWAL, THE SISTERS OF LORETTO, NOUVELLE THÉOLOGIE, AND THE SECOND VATICAN COUNCIL
}

\author{
By \\ Carol Bolton Easterly \\ B.A., Anderson University, 2002

\begin{abstract}
A Thesis
Submitted to the Faculty of the

College of Arts and Sciences of the University of Louisville

In Partial Fulfillment of the Requirements

For the Degree of
\end{abstract}

\author{
Master of Arts \\ in History
}
Department of History University of Louisville
Louisville, Kentucky

August 2020 



\title{
RADICAL RENEWAL: THE SISTERS OF LORETTO, NOUVELLE THÉOLOGIE,
} AND THE SECOND VATICAN COUNCIL

\author{
By \\ Carol Bolton Easterly \\ A Thesis Approved on \\ August 3, 2020 \\ By the following Thesis Committee: \\ Dr. Tracy K'Meyer \\ Dr. Cate Fosl \\ Dr. Theresa Keeley
}




\section{ACKNOWLEDGEMENTS}

I would first like to thank my parents, Lee and Joy Bolton, for their unwavering support and encouragement throughout my graduate school experience. They did not flinch when I, their gainfully employed adult daughter, decided to quit my full time job to pursue the dream of completing a Master's degree. When my car died during the first semester, they told me not to worry, and signed one of their vehicles over to me. I have lost count of the many home maintenance projects they helped with, when I did not have the time or the funds to complete them myself. They were thrilled when I got a job in my field, and let me (and their granddog) regularly crash at their house so I wouldn't have such a long commute. When I met a nice guy, and my thesis completion schedule somehow got completely derailed, they didn't fuss. They even helped pay for the wedding when I married him three years later.

I would also like to thank that nice guy: my husband, Chris Easterly. His loving support and encouragement have been the things that finally pushed me over the finish line. He has willingly served as my cheerleader, personal chef, butler, chauffeur, and comedian, as well as primary caregiver to our pets, over the last few months so that I could focus on writing and editing. While I am duly proud of completing my degree, marrying Chris Easterly is by far the best thing I have ever done.

My advisor, Dr. Tracy K'Meyer, has been eternally patient while I sorted my life out and tried to write a thesis at the same time. I am also grateful for the questions, 
advice, and encouragment of my committee members, Dr. Theresa Keeley and Dr. Cate Fosl. During my coursework, writing papers for Dr. Glenn Crothers helped me to become a better writer. Dr. Dan Vivian's and Dr. Lara Kelland's classes helped me realize what I wanted to actually do with this degree. My lovely colleagues at the Kentucky Historical Society have been a constant source of good humor, advice, and motivation.

Finally, I must thank the amazing Sisters of Loretto, and in particular Sister Eleanor Craig, for welcoming me into the Motherhouse as an archival intern during the summer of 2015. A lapsed Baptist, I had no idea what to expect, having no prior experience or knowledge of the lives of women religious. I certainly did not expect for their stories to feel somehow familiar. Yet as I plumbed the congregation's oral histories, their sense of calling - of having a mission to pursue - resonated with me profoundly. I recognized the same spirit that had animated my own religious education. Their courage and forthrightness became for me an inspiration and a beacon of hope. I am forever grateful. 


\section{ABSTRACT \\ RADICAL RENEWAL: THE SISTERS OF LORETTO, NOUVELLE THÉOLOGIE, AND THE SECOND VATICAN COUNCIL

\author{
Carol Bolton Easterly
}

August 3, 2020

This thesis explores the experiences of women who were members of the Sisters of Loretto, an American congregation of women religious, in the years around the Second Vatican Council (1962-65). It argues that the ideas of nouvelle théologie - a movement among progressive European Catholic scholars aimed at reconnecting faith with lived experience - had a profound impact on how the Sisters of Loretto interpreted the Council's directives. The movement's core ideas: ressourcement, a return to original sources of Christian inspiration; an overlapping relationship between natural and supernatural; and the importance of Church engagement with modern social issues, reshaped the Sisters' understanding of themselves and their role as women religious. As a result of their engagement with nouvelle théologie, encountered through their efforts to improve members' educational opportunities, the Sisters re-oriented their collective work and made other far-reaching changes to their traditional way of life in the immediate post-Conciliar period. 


\section{TABLE OF CONTENTS}

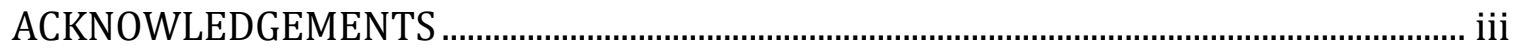

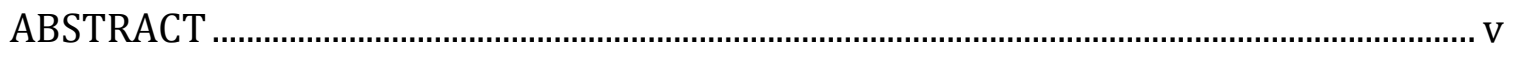

INTRODUCTION

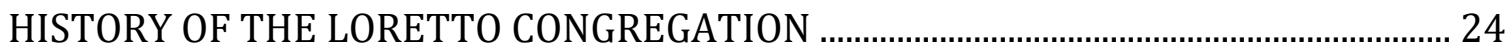

NOUVELLE THÉOLOGIE: HISTORICAL BACKGROUND, KEY IDEAS, AND IMPACT

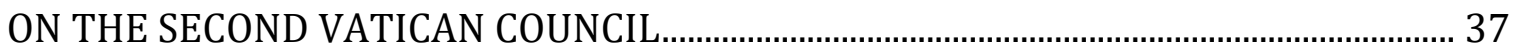

THE SISTERS OF LORETTO EMBRACE NOUVELLE THÉOLOGIE ….................................... 60

CHANGES OF THE POST-CONCILIAR ERA AND IMPACT OF NOUVELLE

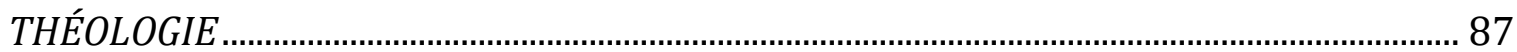

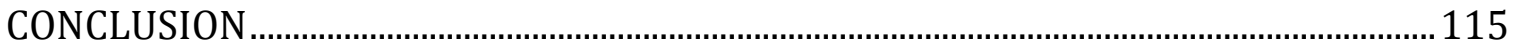

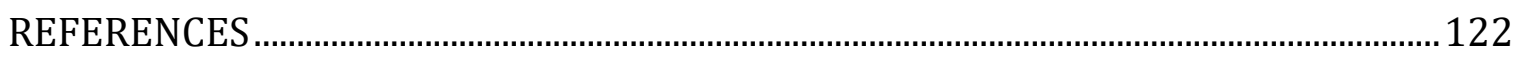

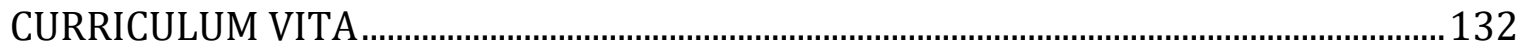




\section{INTRODUCTION}

Maureen O'Connell was the second of eleven children, born into a very traditional, conservative Catholic family in East Saint Louis, Illinois. Because she and her siblings all attended Catholic schools, nuns were familiar figures in their lives -- highly respected women who treated her family with kindness, and who were valued members of the community. O'Connell began to think about joining their ranks as early as the second grade. When she graduated from high school in 1962, her decision to enter the convent seemed perfectly natural. She chose to join the Sisters of Loretto, who had been her teachers at St. Patrick's parish school from the first through the eighth grades. As a new Sister of Loretto, O’Connell could expect that she would also be trained as an educator, and would then be assigned by her superior to teach in a Catholic school or college. ${ }^{1}$

Eleanor Craig, from St. Louis, Missouri, entered the Sisters of Loretto around the same time as O'Connell, having decided to enter religious life while she was a student at Webster College. The two first met during their time as novices, at the Loretto Motherhouse in Kentucky. One day, as they were working together, Craig began to tell O'Connell about her involvement with the Congress of Racial Equality (CORE) on

\footnotetext{
${ }^{1}$ Maureen O'Connell interviewed by Carol Bolton, November 13, 2015, Loretto Jubilee Oral History Project, Kentucky Historical Society, Frankfort, KY.
} 
campus at Webster. She shared her admiration for the work of Dr. Martin Luther King. O’Connell was appalled. "But...," she protested, "he's a Communist!"2

Within a few years, O'Connell's outlook was quite different. She began teaching history and social studies at Loretto High School in Louisville, Kentucky, in 1968, and was soon attending meetings of the West End Community Council, a local civil rights organization. Community activists were regular guests in O'Connell's classroom, though this practice often drew criticism from her students' parents, particularly when a class speaker was arrested only a few days after visiting. O'Connell also organized grocery store boycotts in support of the United Farm Workers and participated in numerous marches and protests against the Vietnam War. She became close friends with Anne Braden, a Louisville civil rights leader once indicted for supposed communist activities. After several years of teaching, O'Connell moved to Tennessee, where she lived outside of a traditional convent setting. There she spent the next 35 years working as a community organizer in rural Appalachia. For O'Connell, faith in God was the basis of her activism. She had come to believe that "this was the call of the Gospel."

Though each Loretto Sister's story is unique, O'Connell's bears important similarities to many others who were members of the congregation during the era of the Second Vatican Council, in that their lives took very different courses than what they may have expected upon entering the convent. Pope John XXIII called this meeting of ecclesiastical officials from around the world to examine Church doctrine and practices. Among many other changes to church life, the Fathers in attendance called for renewal

\footnotetext{
${ }^{2}$ Eleanor Craig. Conversation with the author, November 13, 2015.

${ }^{3}$ Maureen O'Connell interviewed by Carol Bolton, November 13, 2015, Loretto Jubilee Oral History Project, Kentucky Historical Society, Frankfort, KY.
} 
among religious orders - specifically, for vowed congregations to examine their ways of life, and to update their practices to be more in tune with the modern world. In response to these directives, the Sisters of Loretto underwent a series of radical changes to their traditional way of life, as did many other congregations of women religious at the time.

Though the Council's decisions impacted the lives of millions of Catholic women, only 23 were permitted to actually attend any sessions, beginning during the third of the Council's four gatherings. Among these favored few was Sister Mary Luke Tobin, then serving as Superior General of the Sisters of Loretto. In this capacity, Tobin had also been elected President of the Council of Major Superiors of Women (CMSW), the national leadership organization representing American orders of women religious. Her prominence in American Catholic life made Tobin a natural choice to represent U.S. women's congregations at the Vatican.

After the Council's final session ended, the hard work of implementing its directives toward the renewal of religious life began in earnest. For the Sisters of Loretto and other progressive religious orders, however, the Council documents were not the beginning of major change, but rather continued and accelerated trends that had begun as early as 1948. Tobin, in particular, had worked to keep her congregation well informed about emerging influential ideas in Catholic theology. Through the congregation's efforts to improve members' education and spiritual formation during the $1950 \mathrm{~s}$ and early $60 \mathrm{~s}$, Tobin and the Sisters of Loretto began to engage with the ideas of nouvelle théologie, a movement among some European Catholic scholars aimed at reconnecting Catholic theology with parishioners' daily lives and experiences. Nouvelle théologie emphasized ressourcement (a return to original sources of Christian inspiration), increased church 
engagement with modern social issues, and an overlapping relationshp of the natural with the supernatural. As the Sisters of Loretto studied and embraced these concepts, nouvelle théologie served to reorient the Sisters' understanding of their role as women religious, both within the Church and the wider world, leading them to enact far-reaching changes to their community structure, their spiritual practices, and the focus of their employment in response to the Council's directives toward renewal of religious life.

Historiography

The connection between theology and Sisters' response to Vatican II is a topic that warrants scholarly inquiry, as it has yet to be thoroughly analyzed by historians of women religious, other than brief acknowledgments in some studies. This is somewhat surprising, given that there has been increased interest and a wide variety of publication on Sisters' history since the early 1990s. Prior to that, Sisters' history received comparatively little historical analysis, other than studies and reflections published by Sisters about their own experiences. Bernadette McCauley, in her 2014 essay, 'Nuns' Stories: Writing the History of Women Religious in the United States," points to the first gathering of the Conference on the History of Women Religious, held in 1989, as giving rise to the explosion of scholarship since that time on the history of nuns. ${ }^{4}$ Helen Rose Ebaugh's 1993 article, "Patriarchal Bargains and Latent Avenues of Social Mobility: Nuns in the Roman Catholic Church," is an early example. Ebaugh argues that women religious historically struck "patriarchal bargains" with male church hierarchy, through which they gained access to education, social mobility, etc., in exchange for performing vital social functions of the church. She concludes that this bargain changed with the

\footnotetext{
${ }^{4}$ Bernadette McCauley. "Nuns' Stories: Writing the History of Women Religious in the United States," American Catholic Studies 125, no. 4 (Winter 2014): 51-68.
} 
documents of Vatican II, and women religious began to challenge the church power structures that subordinated them. ${ }^{5}$

Jo Ann Kay McNamara’s Sisters in Arms: Catholic Nuns Through Two Millennia, published in 1996, is one of the first general histories of women religious, offering an indepth study of the development of Catholic women's orders, from the Roman Empire into modern times, though the post Vatican II era receives only limited discussion. McNamara focuses her analysis principally on the issue of gender, and how the norms enforced by the male hierarchy of the Church shaped the development of religious women's communities over time. ${ }^{6}$ Elizabeth Rapley's The Lord as Their Portion: The Story of the Religious Orders and How They Shaped Our World (2011) is another broad study, tracing the history of both male and female religious orders, from early Christianity through the nineteenth century. She demonstrates the essential role these groups played in the development of Western civilization and the spread of Christianity around the world. ${ }^{7}$ Taking a somewhat different approach, Elizabeth Kuhns' The Habit: A History of the Clothing of Catholic Nuns, released in 2003, surveys the distinctive garb worn by women religious until the post Vatican II era, across multiple communities. The author discusses the evolution of various elements of Sisters' habits, in response to social

\footnotetext{
${ }^{5}$ Helen Rose Ebaugh. "Patriarchal Bargains and Latent Avenues of Social Mobility: Nuns in the Roman Catholic Church," Gender and Society 7, no. 3 (September 1993): 400-414.

6 Joann Kay McNamara. Sisters in Arms: Catholic Nuns Through Two Millennia (Cambridge, MA: Harvard University Press, 1996).

${ }^{7}$ Elizabeth Rapley. The Lord as Their Portion: The Story of the Religious Orders and How They Shaped Our World. (Grand Rapids, MI: Wm. B. Eerdmans Publishing Co., 2011).
} 
and cultural change, and also explains the habit's profound symbolism, both for women religious themselves, and those they encountered in their ministries. ${ }^{8}$

Other historians have placed Catholic women religious within the context of broader social and religious movements. Dana Robert, for example, in her 1997 study American Women in Mission: A Social History of Their Thought and Practice, details the growth of the modern missionary movement among American women, both Protestant and Catholic, analyzing their theological and cultural motivations. ${ }^{9}$ In 1998, Angelyn Dries published a more focused work on this topic, The Missionary Movement in American Catholic History. ${ }^{10}$ Ann Braude's Sisters and Saints: Women and American Religion (2008), explores the varying roles that women, including Catholic Sisters, have played over time within the landscape of American religious thought and practice. The author argues that women have been, and continue to be, essential to the growth of religious institutions as well as the dissemination and continuance of theology and customs. She concludes that American women of all religious affiliations have drawn strength from their faith, in spite of their exclusion from most denominational leadership roles, and the use of theology to enforce a secondary, submissive role. ${ }^{11}$

Also focused on the United States, George C. Stewart's Marvels in Charity: History of American Sisters and Nuns (1994) represents the first comprehensive history

\footnotetext{
${ }^{8}$ Elizabeth Kuhns. The Habit: A History of the Clothing of Catholic Nuns (New York: Doubleday, 2003).

9 Dana Robert. American Women in Mission: A Social History of Their Thought and Practice (Macon, GA: Mercer University Press, 1997).

${ }^{10}$ Angelyn Dries. The Missionary Movement in American Catholic History. (Ossining, NY: Orbis Books, 1998).

${ }^{11}$ Ann Braude. Sisters and Saints: Women and American Religion (Oxford, UK: Oxford University Press, 2008).
} 
of specifically American Catholic Sisters. ${ }^{12}$ Margaret McGuinness provides a welcome update to this work with her 2013 book, Called to Serve: A History of Nuns in America. McGuinness demonstrates the integral role Sisters have played in the development of the institutional Catholic Church in the United States, and highlights Sisters' more recent and ongoing ministries and activities. The sheer breadth of McGuinness's work necessitates somewhat superficial analysis, but the variety of perspectives she includes is helpful. ${ }^{13}$ Another notable publication, Carol Coburn and Martha Smith's Spirited Lives: How Nuns Shaped Catholic Culture and American Life, 1836-1920, examines the early history of the Sisters of St. Joseph of Carondolet, exploring the ways these women adapted to and used traditional gender ideology to justify and expand their roles in public life. Because they cover one of the larger congregations of women religious, involved in multiple forms of ministry throughout the country, the authors argue that their history can provide insight into the broader history of American Catholic Sisters and their influence on the development of Catholic culture and American life. ${ }^{14}$ John Fialka's Sisters: Catholic Nuns and the Making of America similarly uses the Sisters of Mercy, once the largest congregation of women religious in the U.S., as a lens through which to view the larger story of American Catholic Sisters. Fialka argues that Catholic Sisters have been an essential element in the development of the United States, founding numerous institutions that provided essential services, including education, healthcare, and social welfare, to

\footnotetext{
${ }^{12}$ George C. Stewart. Marvels in Charity: History of American Sisters and Nuns. (Huntington, IN: Our Sunday Visitor, 1994).

${ }^{13}$ Margaret McGuinness. Called to Serve: A History of Nuns in America (New York and London: New York University Press, 2013).

${ }^{14}$ Carol Coburn and Martha Smith. Spirited Lives: How Nuns Shaped Catholic Culture and American Life, 1836-1920 (Chapel Hill: University of North Carolina Press, 1999).
} 
the country's growing immigrant population, and provides helpful context regarding the important role that Sisters played in the communities they served. ${ }^{15}$

Another important set of literature on the history of women religious offers varying perspectives on the profound changes to religious life that have taken place since the 1960s. A good starting point is Lora Ann Quiñonez and Mary Daniel Turner's The Transformation of American Catholic Sisters (1992), which discusses the history of the Leadership Conference of Women Religious (LCWR), whose members represents a majority of women's orders in the United States. They argue that the development of this organization reflected many of the changes occurring within Catholic women's orders, and thus use its history as a tool for understanding the broader story of American Sisters in the post-Vatican II era. ${ }^{16}$

Several authors have focused specifically on the role played by the Sister Formation Conference (SFC) in inpiring the changes of the post Vatican II era. Mary L. Schneider recognized this as early as 1988, in her article "American Sisters and the Roots of Change: the 1950s." Arguing that the changes in religious life can actually be traced to orders' cooperative efforts to improve Sister education and formation programs, Schneider cites the SFC and its newsletter, the Bulletin, as an important means of disseminating new ideas, particularly those of progressive European theologians who became influential at the Second Vatican Council. ${ }^{17}$ Marjorie Noterman Beane's From Framework to Freedom: A History of the Sister Formation Conference (1993) represents

\footnotetext{
${ }^{15}$ John Fialka. Sisters: Catholic Nuns and the Making of America (New York: St. Martin's Press, 2003).

${ }^{16}$ Lora Ann Quiñonez and Mary Daniel Turner, The Transformation of American Catholic Sisters (Philadelphia: Temple University Press, 1992).

${ }^{17}$ Mary L Schneider. "American Sisters and the Roots of Change: the 1950s." U.S. Catholic Historian 7, no.1 (Winter 1988): 55-72.
} 
the first book-length study of the SFC, offering a detailed description of its early development, highlighting the Sisters who played prominent roles in the organization, and discussing the controversy surrounding its transferral to control by the Conference of Major Superiors of Women (CMSW). ${ }^{18}$

Angelyn Dries also focused on the SFC in her 1993 article, "Living in Ambiguity: A Paradigm Shift Experienced by the Sister Formation Movement," in which she describes intellectual change within the SFC. Dries argues that the organization's leaders transitioned from a Neo-scholastically influenced paradigm to one reflective of more progressive theology, and the "mystical body" understanding of the Church. ${ }^{19}$ Dara Mulderry builds on this in her 2006 dissertation, "'What Human Goodness Entails:' An Intellectual History of U.S. Catholic Sisters, 1930-1980,” describing a broad intellectual shift among American Catholic Sisters during the middle and later twentieth century. She attributes this to the influence of the Sister Formation Conference, whose publications and workshops served as important resources for many American congregations during the pre and post Vatican II years. Mulderry draws connections between the philosophies of education and religious life proposed by the SFC, and the specific types of changes enacted by many women's orders in response to Vatican II. ${ }^{20}$ More recently, Carol Coburn has discussed the long term impact of the SFC in her 2015 article "Ahead of Its Time...or Right on Time? The Role of the Sister Formation

\footnotetext{
18 Marjorie Noterman Beane. From Framework to Freedom: A History of the Sister Formation Conference. (Lanham, MD: University Press of America, 1993).

${ }^{19}$ Angelyn Dries. "Living in Ambiguity: A Paradigm Shift Experienced by the Sister Formation Movement," The Catholic Historical Review 79, no. 3 (July 1993): 478487.

${ }^{20}$ Dara Mulderry. "'What Human Goodness Entails:' An Intellectual History of U.S. Catholic Sisters, 1930-1980," (PhD diss., Brandeis University, 2006).
} 
Conference for American Women Religious." She too argues for the organizaton's influence as a primary catalyst for the changes enacted by many American communities of women religious in the wake of Vatican II. Like Schneider, Coburn points to the Bulletin and the "cutting edge theology" Sisters found in its pages. ${ }^{21}$

Mulderry has continued to publish more focused, analytical work related to the Sister Formation Conference. Her 2015 article, “Educating 'Sister Lucy:' The Experiential Sources of the Movement to Improve Higher Education for Catholic Teaching Sisters, 1949-1964" focuses on the foundational educational experiences of Sisters prominent in the Sister Formation movement, particularly Madaleva Wolff and Mary Emil Penet, whose speeches helped to catalyze the organization of the SFC. Mulderry argues that these "college sisters" high level of education and experience of academic mentorship resulted in a shared vision for cultivating the latent intellectual abilities of their fellow Catholic women religious. Their articulation of this vision held broad appeal for the majority of American sisters, whose educational and personal development had historically taken a back seat to increasing demand for their services. ${ }^{22}$ In 2017, Mulderry offered "'People are Suffering; People are Christ, and We Are Responsible': Sister Mary Emil Penet's Campaign for Social-Justice Education in the 1950s." This article explores the intellectual development of Sister Mary Emil Penet, first chairwoman of the Sister Formation Conference, and a key figure in the development of its model college curriculum for sisters. Mulderry contends that while Penet actively

\footnotetext{
${ }^{21}$ Carol Coburn. "Ahead of Its Time... or Right on Time? The Role of the Sister Formation Conference for American Women Religious." American Catholic Studies 126, no. 3 (Fall 2015): 25 - 44.

${ }^{22}$ Dara Mulderry. "Educating 'Sister Lucy:' The Experiential Sources of the Movement to Improve Higher Education for Catholic Teaching Sisters, 1949-1964." U.S. Catholic Historian 33, no. 1 (Winter 2015): 55 - 79.
} 
supported educating sisters for "social justice," her understanding of this concept was rooted in Thomistic philosophy and the Catholic Action movement of the 1930s. In this respect, Penet's views on social justice ultimately differed from those of younger Sisters, who were influenced by the more progressive, experiential theology gaining influence in the 1950s and 60s. She concludes that this theology influenced many American Catholic sisters to abandon traditional apostolates in favor of direct action on a variety of social issues. $^{23}$

While Mulderry, Dries, Coburn, and Schneider have all pointed to progressive theology as an important factor in the far-reaching changes enacted by many communities of American women religious in response to Vatican II, this connection has not been explored in depth. Mulderry comes closest, specifically mentioning writers and basic ideas associated with the nouvelle théologie, though she does not use this identifier. The term nouvelle théologie has, in fact, rarely been used by scholars of women religious. This could be due to the fact that much of the available in depth scholarly analysis of nouvelle théologie as a movement was published only somewhat recently, since the mid 2000s. The work of religious scholars Jürgen Mettpenningen, Hans Boersma, Fergus Kerr, Gerald O'Collins, Gabriel Flynn, Paul Murray, John O'Malley and others has been helpful in identifying the key concepts of nouvelle théologie and the prominent figures associated with the movement, as well as understanding the lasting impact these ideas have had on the Catholic Church as a whole and women religious in particular. With the help of these theological studies, I hope to provide clarification and deeper analysis of the

${ }^{23}$ Dara Mulderry. "People are Suffering; People are Christ, and We Are Responsible': Sister Mary Emil Penet's Campaign for Social-Justice Education in the 1950s." The Catholic Historical Review 103, no. 4 (Autumn 2017): 725-754. 
relationship between midcentury progessive Catholic theology and the specific changes enacted by the Sisters of Loretto in the post Vatican II era. While my work focuses on only one order's experiences, I hope that it will provide insight for understanding the decisions of other congregations as they, too, interpreted and responded to the dictates of the Council.

Finally, a number of scholars have explored how theological changes, and changes within the church, led to women religious being involved in contemporary social movements. Amy Koehlinger, in The New Nuns: Racial Justice and Religious Reform in the 1960s (2007) examines efforts by American Catholic Sisters to promote racial justice during a decade when many congregations were also experiencing radical changes to their way of life. She discusses the origins of this "racial apostolate" among Sisters and argues that their involvment had a profound impact on the women who participated, changing the way they understood their role as women religious. ${ }^{24}$ While Koehlinger's work focuses primarily on the experiences of white women religious, Shannen Dee Williams' work is bringing needed scholarly attention to the experiences of black Catholic Sisters, both within predominantly white convent settings, and in specifically black congregations such as the Oblate Sisters of Providence (OSP). Her first book, Subversive Habits: The Untold Story of Black Catholic Nuns in the United States, is forthcoming. In addition to racial equality, some American Sisters have also embraced working for environmental justice, a topic Sarah McFarland Taylor discusses in Green Sisters:A Spiritual Ecology. This 2007 study explores the activism and spirituality of women she terms "green sisters:" groups of American Catholic women religious who feel

${ }^{24}$ Amy Koehlinger. The New Nuns: Racial Justice and Religious Reform in the 1960s (Cambridge, MA and London: Harvard University Press, 2007). 
called to help restore the planet through sustainable living and farming practices, as well as environmental education efforts. ${ }^{25}$ Carol Garibaldi Rogers presents a variety of Sisters' post Vatican II experiences in Habits of Change: An Oral History of American Nuns $(2011) \cdot{ }^{26}$

Background

To better understand the momentous nature of the changes in religious life following the Second Vatican Council, it is necessary to establish a basic framework for understanding what vowed religious life is, how it was practiced prior to the Vatican II era, and the meaning and purpose this way of life historically had within the larger context of American Catholicism. Women religious in the Catholic Church, also referred to as "nuns," are considered consecrated individuals, meaning that they are set apart for special service to God and the Church. I use the terms "women religious" and "nuns" interchangeably, as this is common practice in Catholic life. It is important to note, however that these terms technically refer to two different forms of religious life. Women religious typically perform some type of active ministry, maintaining a degree of contact with the world outside their religious community. Nuns, on the other hand, are members of cloistered communities, meaning that they devote themselves to contemplation and prayer within their convents, and maintain little or no direct contact with secular life.

Whatever form it takes, individuals who choose to enter religious life believe themselves to have a vocation, or calling, to the consecrated life, communicated to them by God. Consecrated life has historically had some unique characteristics that distinguish

\footnotetext{
${ }^{25}$ Sarah McFarland Taylor, Green Sisters: A Spiritual Ecology (Cambridge, MA and London: Harvard University Press, 2007).

${ }^{26}$ Carol Garibaldi Rogers. Habits of Change: An Oral History of American Nuns. (Oxford, UK: Oxford University Press, 2011).
} 
it from lay, or secular, Catholic life. One of the most distinctive features is that upon entering, individuals must profess vows of poverty, chastity, and obedience. Through profession of these vows, a religious renounces individual claim to money and possessions, embraces a life of celibacy, and promises to be obedient to the will of God through the authority of her Superior, the leader of her congregation. Based on the life and teachings of Christ, these vows are known collectively as the Evangelical Counsels, or the Counsels of Perfection. They are meant to foster a life of personal holiness, and to free the woman religious from worldly concerns so that she is able to focus all her energy and attention on serving God. ${ }^{27}$

In addition to profession of vows, a woman religious leaves behind her former life among secular family and friends, to live with other consecrated women in a communal setting. The Catholic Church also recognizes eremitic and anchoritic vocations (i.e., complete withdrawal from society to live a life of prayer and contemplation in seclusion) as legitimate forms of consecrated life. However, the majority of consecrated women have been members of a religious institute. ${ }^{28}$ (Institutes may also be referred to as congregations, communities, or orders.) The members of a religious institute have historically lived together in a group setting, in a building or collection of buildings known as a convent or an abbey, sharing a daily schedule of prayer, worship, other devotional activities, meals, work, and recreation.

\footnotetext{
27 “Canons 573 - 575," and “Canons 599 - 601," Code of Canon Law, The Vatican, accessed September 2, 2016, http://www.vatican.va/archive/ENG1104/_P1Y.HTM. Coburn and Smith, Spirited Lives, 9-10.

28 “Canon 603," Code of Canon Law, The Vatican, accessed September 2, 2016, http://www.vatican.va/archive/ENG1104/_ P1Y.HTM.
} 
The semi-secluded religious way of life first developed during the fourth century, in the deserts of Egypt. ${ }^{29}$ During this period, following the legalization of Christianity by the emperor Constantine, some devout Christians seeking deeper spiritual experience and personal holiness began renouncing their secular lives and material goods to seek solitude in the desert, where they devoted themselves to an ascetic life of prayer and penitence. Other Christians soon followed, seeking instruction from these "desert fathers," as they were later called, and monastic communities developed rapidly under their leadership. ${ }^{30}$ Both men and women joined monastic communities, and occasionally lived together communally, but were most often strictly segregated by sex. Monasticism migrated from Egypt to Europe during the fifth century, but grew slowly there due to the social and political upheaval created by the movement of various tribes across the Continent, following the fall of the Roman Empire, and later invasions by the Vikings. The turn of the millennium brought greater stability, and both male and female monastic communities, including the Benedictines, the Cistercians, and the Order of St. Francis, flourished on the Continent as well as the British Isles. ${ }^{31}$

Religious communities for women have historically been hierarchical, governed by an abbess or superior, who bore responsibility for the physical and spiritual wellbeing of her community. Though the Superior might be elected, her authority was considered final, and disobedience could result in disciplinary action. ${ }^{32}$ A community's Superior, perhaps with help from a delegate, was responsible for the admission of new applicants to

${ }^{29}$ McGuinness, Called to Serve, 2.

${ }^{30}$ Rapley, The Lord as Their Portion, 1-4.

${ }^{31}$ McGuinness, Called to Serve, 2-3. Rapley, The Lord as Their Portion, 5-8.

${ }^{32}$ McNamara, Sisters in Arms, 116. 
the community, called postulants. The Superior also oversaw the training and adjustment period required of new members, referred to as the novitiate, before the profession of their final, or perpetual vows. ${ }^{33}$

Each community's governance structures, as well as other practices and customs such as the length of the postulancy and novitiate periods, and specific training required therein - are set forth in their Rule, a constitutional document that is unique to each religious institute. ${ }^{34}$ The practice of establishing a written rule for religious communities originated with St. Pachomius, one of the early desert fathers to gather a monastic community of followers around him. ${ }^{35}$ The Rule of St. Pachomius served as the foundation for numerous desert religious communities. It also influenced the continued development of religious rules throughout the Middle Ages as communities refined their practices, learning from the body of monastic literature that developed around this topic. ${ }^{36}$ As the Church's ecclesiastical hierarchy in Rome developed, it became a requirement that all religious communities submit their Rule for examination and approval by the Vatican. ${ }^{37}$ A Vatican "Congregation" (i.e., bureaucratic office) specifically dealing with the affairs of religious institutes was first established in 1586, by Pope Sixtus V. It is known today as the Congregation for Institutes of Religious Life and Societies of Apostolic Life. ${ }^{38}$

${ }^{33}$ Coburn and Smith, Spirited Lives, 8-9.

34 "Canon 578," and "Canon 587," Code of Canon Law, The Vatican, accessed September 2, 2016, http://www.vatican.va/archive/ENG1104/_P1Y.HTM.

${ }^{35}$ Rapley, The Lord as Their Portion, 4.

${ }^{36}$ McNamara, Sisters in Arms, 112.

37 “Canon 587," Code of Canon Law, The Vatican, accessed September 2, 2016, http://www.vatican.va/archive/ENG1104/ P1Y.HTM.

38، The Congregation for Institutes of Religious Life and Societies of Apostolic Life," The Vatican, accessed September 8, 2016, 
One topic likely to be addressed by a religious community's rule is their collective apostolate, or mission - the specific work they devote their energies to. The earliest women religious focused their lives on prayer, worship, and contemplation, cloistering themselves within their convents, as a means of protection from both spiritual temptation and physical harm. ${ }^{39}$ This cloistered, contemplative model was the standard for religious life until the Early Modern period, when congregations began to emerge who pursued active apostolates, meaning that they engaged in works of ministry outside their convent walls, which brought them into regular contact with laypeople. Responding to the needs they witnessed in their localities, Sisters most often taught young women, cared for the sick, or tended to the needs of the poor. They faced opposition from Church hierarchy, however, who insisted that women religious must remain cloistered, in accordance with Church law. Active women's orders such as the Ursulines and the Daughters of Charity, which had been founded for the purpose of serving God through works of charity in their communities, found ways around this requirement, however. The Ursulines, for example, were allowed to continue teaching young women as long as they agreed to conduct their schools within the convent walls. The Daughters of Charity chose to take only simple, or temporary vows, instead of perpetual vows. This practice excluded them from full recognition as a religious order, but allowed them the freedom to continue their charitable work. The work of such communities was so desperately needed that they were ultimately allowed to continue and expand, paving the way for additional women's orders to engage in teaching, nursing, and providing services to the poor.

http://www.vatican.va/roman curia/congregations/ccscrlife/documents/rc con ccscrlife profile en.html.

${ }^{39}$ McNamara, Sisters in Arms, 98-99. 
Both these forms of religious life, contemplative and active, are still practiced by communities of women religious today. ${ }^{40}$ In the United States, active communities represent the predominant form of Catholic religious life. Already highly valued in the European cities they served, demand for the work of active congregations only increased with colonization in the Americas. European communities such as the Ursuline Sisters, the Daughters of Charity, and the Sisters of St. Joseph sent contingents of missionary Sisters to work in North America throughout the 18th and 19th centuries. Along with newly established American orders such as the Sisters of Loretto these women established schools, hospitals, and orphanages for the growing population of settlers. As the young United States rapidly expanded, Sisters migrated westward, gradually building a vast network of Catholic social institutions across the country, to serve the rising population of Catholic immigrants. ${ }^{41}$

Active congregations were highly visible in the communities they served, due to another important feature of religious life: the distinctive garb historically worn by women religious. Known as a habit, this typically consisted of a long, loose fitting gown, often dark in color, and a veil that covered the wearer's hair. The habit originated in

${ }^{40}$ Recent studies of Sisters' lives have tended to focus, necessarily, on active communities, as the practice of claustration limits the public availability of information on contemplative communities. A fascinating recent work, however is Dedicated to God: An Oral History of Cloistered Nuns, by Abbie Reese (Oxford: Oxford University Press, 2014). The Poor Clare Colettines of Corpus Christi Monastery in Rockford, IL, allowed Reese unprecedented access to their community over a period of six years, providing interviews and also consenting to be photographed and filmed. In addition to her book, Reese also produced a multimedia exhibit, Erased from the Landscape: The Hidden Lives of Cloistered Nuns, and a companion album created with tracks from the Sisters' oral history interviews. A collaborative documentary film, Chosen (Custody of the Eyes) was released in 2017. More information is available at http://www.erasedfromthelandscape.com/ and https://www.chosenthefilm.com/.

${ }^{41}$ McGuiness, Called to Serve, 3-7, 41-55. 
Europe during the Middle Ages, as a way to distinguish Sisters from members of the upper classes of society, and to promote humility by blurring class distinctions among members of a congregation. ${ }^{42}$ The habit was later mandated by Church law, as a visual symbol of Sisters' consecration. The veil, along with a ring, were meant to symbolize the Sisters' spiritual marriage to Christ. ${ }^{43}$ Though details of the habit, particularly the shape of the headdress, could vary significantly among different congregations, the basic composition remained the same from the medieval period until the middle of the twentieth century.

To the communities they served, women religious particularly in the United States became a living representation of the Catholic Church. ${ }^{44}$ In the nineteenth and early twentieth centuries, Sisters outnumbered priests in America by approximately four to one. ${ }^{45}$ Lay Catholics, as well as non-Catholics, had far more regular interaction with Sisters than they did with parish priests. ${ }^{46}$ For this reason, Church leadership viewed the work of Sisters as integral to preserving and propagating the Catholic faith in America, which was considered a mission field until $1908 .{ }^{47}$ In a country with strong anti-Catholic

\footnotetext{
${ }^{42}$ Ibid., 3. McNamara, Sisters in Arms, 116-117. 1908. See Spirited Lives, pg. 8, pgs. 84-85.

${ }^{43}$ McGuinness, Called to Serve, 3.

${ }^{44}$ Ibid., 196.

${ }^{45}$ Braude, Sisters and Saints, Kindle edition, location 747.

${ }^{46}$ Coburn and Smith, Spirited Lives, 98-99, 222. McGuinness, Called to Serve, 8.

${ }^{47}$ Robert, American Women in Mission, 318.
}

Coburn and Smith have also shown that, in some orders, the habit was actually used to reinforce class distinctions. In the Sisters of St. Joseph of Carondelet, upper class "choir sisters" wore different habits than working class "lay sisters," who were often required to perform manual labor, such as cooking and cleaning. They also point out that this practice was not typical of American congregations, but was more often seen in European congregations. The Sisters of St. Joseph of Carondelet abandoned class distinctions in 
bias, they provided a much-needed point of contact with the Church for Catholic immigrants wishing to retain their historic faith. Through the vital educational, healthcare, and social services they provided, Sisters also had opportunities to establish connections with the Protestant community, an important way to help diffuse the antiCatholic sentiment they encountered. ${ }^{48}$

Sisters were highly valued and respected in the communities they served, for the services they provided, and for their religious devotion and moral character. Though not considered clergy, they were not laity either, and occupied an elevated position within Catholic life. ${ }^{49}$ Consecrated life was looked upon as a higher calling than secular life, and Catholic families generally considered it an honor to have a daughter enter the convent. For Catholic young women who did not wish to marry and raise children, entry into religious life offered a respectable alternative path, that also promised opportunities not always available to laywomen of the nineteenth and early twentieth centuries: higher education, meaningful work (with the added possibility of organizational leadership roles), travel, and a supportive female community to nurture their individual talents. ${ }^{50}$

Because of the great demand for the services provided by American Catholic Sisters, the high regard in which they were held, as well as the educational and professional opportunities they provided to young women, the population of Sisters in the United States grew exponentially during the nineteenth and early twentieth centuries, reaching 46,000 by 1900 and 90,000 by $1920 .^{51}$ It reached its peak in 1965 , at which time

\footnotetext{
${ }^{48}$ Fialka, Sisters, 8-9.

${ }^{49}$ McGuinness, Called to Serve, 9, 70.

${ }^{50}$ Coburn and Smith, Spirited Lives, 3-4, 8-10, 221-222. Fialka, Sisters, 2.

${ }^{51}$ Coburn and Smith, Spirited Lives, 2.
} 
there were approximately180,000 women religious living in American convents. ${ }^{52}$ In the same year, the Second Vatican Council held its third and final session in Rome. On October 28, Pope Paul VI promulgated one of the Council's major documents, Perfectae Caritatis, which instructed religious orders to examine their customs and practices, and to update their rules to be more in tune with modern life. ${ }^{53}$ The Sisters seemed poised to continue growing and expanding their already broad network of schools, hospitals, and social service institutions.

Many lay Catholics found it shocking and disturbing, then, that many women religious began to look and act quite differently than the quiet and dutiful Sisters to which they had been accustomed. Sisters began boldly speaking out on social and political issues of the day, even showing up to marches and protests, creating quite a spectacle in their flowing habits and veils. Soon, however, even this familiar symbol began to disappear as many Sisters abandoned the habit in favor of modern secular clothing. Sisters began to move out of the convent houses that had long been their homes, and to live among the communities they served. Some also left behind their traditional professions of teaching, nursing, and social work, to take on new careers, such as the law, community organizing, medicine, and psychology. They continued their activism, as well, supporting civil rights for African Americans, fair labor practices for farm workers and miners, women's equality, and efforts to combat poverty and protect the

\footnotetext{
${ }^{52}$ Michael Lipka, "U.S. Nuns face shrinking numbers and tensions with the Vatican," Fact Tank, August 8, 2014, accessed September 12, 2016, http://www.pewresearch.org/fact-tank/2014/08/08/u-s-nuns-face-shrinking-numbers-andtensions-with-the-vatican/.

53 "Decree on the Renewal of Religious Life: Perfectae Caritatis," The Vatican, accessed September 12, 2016, http://www.vatican.va/archive/hist_councils/ii_vatican_council/documents/vatii_decree_19651028_perfectae-caritatis_en.html.
} 
environment. They also voiced their objections to U.S. involvement in Vietnam and to nuclear arms, at times risking arrest and/or ecclesiastical censure for their actions. This did not seem to deter them, however, as more Sisters became willing to openly criticize Church policies and practices. ${ }^{54}$

Perhaps even more shocking for Catholic parishioners, the number of Sisters in the United States sharply declined in the years following the Second Vatican Council as many chose to leave religious life. Between 1965 and 1975, the population of American women religious decreased by roughly 45,000 , and has continued to decline since that time. ${ }^{55}$ Sisters left for a variety of reasons. Amid so much rapid change, many questioned their vocation to religious life, with some expressing a newfound desire to marry. Others

${ }^{54}$ For more in depth discusson of Sisters' activism around these issues, see Amy Koehlinger, The New Nuns: Racial Justice and Religious Reform in the 1960s (Cambridge, MA and London: Harvard University Press, 2007), Sarah McFarland Taylor; Green Sisters: A Spiritual Ecology (Cambridge, MA and London: Harvard University Press, 2007); Helen Sanders, SL, "Conflicting Values Surface," and "The Corporate Vision Matures," in More Than a Renewal - Loretto Before and After Vatican II: 1952-1977 (Nerinx, KY: Sisters of Loretto, 1982); Ann Patrick Ware, ed., Naming Our Truth: Stories of Loretto Women (Oakland, CA: Chardon Press, 1995); Mary Luke Tobin, SL, "The Door of Social Justice: Vietnam and After," and "The Door of Global Involvement: Current Oppressions," in Hope is an Open Door (Nashville: Abingdon Press, 1981); Ann Patrick Ware, ed., Midwives of the Future: American Sisters Tell Their Stories (Kansas City, MO: Leaven Press, 1985); Margaret McGuinness, "Serving Today," in Called to Serve: A History of Nuns in America (New York and London: New York University Press, 2013).

${ }^{55}$ In 1965 , there were approximately 180,000 Sisters in the United States, representing the peak population of American women religious. See Michael Lipka, "U.S. nuns face shrinking numbers and tensions with the Vatican," Pew Research Center, August 82014. Accessed July 27, 2020, https://www.pewresearch.org/fact-tank/2014/08/08/u-s-nunsface-shrinking-numbers-and-tensions-with-the-vatican/.

By 1970, there were 160,931 Sisters, and by 1975 their numbers had dropped to 135,225. See "Frequently Requested Church Statistics," Center for Applied Research in the Apostolate, Georgetown University. Accessed July 27, 2020, https://cara.georgetown.edu/frequently-requested-church-statistics/. 
did not support the types of changes they saw happening in their orders, and felt they could not remain. As many vowed Sisters were leaving religious life, fewer and fewer young women expressed interest in joining.

The Sisters of Loretto were in the vanguard of those congregations who embraced new roles and practices during the post-Conciliar years. Their early engagement with nouvelle théologie, in the decade prior to the Council, had laid the groundwork for the shift in their perspectives regarding their roles as women religious. This thesis will demonstrate that process beginning with the early history of the Sisters of Loretto prior to the Vatican II era, the development of nouvelle théologie within the Catholic Church, the Sisters' changing understanding of their roles as they engaged with nouvelle théologie during the 1950 s and early 60 s, and finally the influence of nouvelle théologie upon the specific changes they enacted in the late 1960 s and early 70 s. 


\section{HISTORY OF THE LORETTO CONGREGATION}

Mary Rhodes first arrived in Kentucky in 1811. With a group of fellow settlers, she had journeyed west from Maryland to join her brother and his family on the frontier, where they hoped to find greater economic opportunity and to practice their Catholic faith without fear of persecution. Their tiny community on Hardin's Creek was a far cry from the established towns Rhodes had known in the east, however. There were a growing number of Catholic families in Kentucky, yet few priests were available to attend to their spiritual needs or provide religious instruction.

Rhodes was dismayed to discover that the community's children, including her nieces and nephews, were receiving no formal education, because there was no local school for them to attend. A devout, unmarried woman, Rhodes determined to serve God by providing a Catholic education for the local children, and opened a school in a rough cabin on her brother's property. Two additional young single women, Nancy Havern and Christina Stuart, joined Rhodes in teaching in the log cabin schoolhouse. The three women shared a deep religious devotion, and developed a strong friendship. They soon approached Father Charles Nerinckx, the local priest, and expressed their desire to devote themselves fully to Christ and the Church as a community of women religious. ${ }^{56}$

\footnotetext{
${ }^{56}$ See Hannah O'Daniel's Southern Veils: The Sisters of Loretto in Early National Kentucky (M.A. Thesis, University of Louisville, 2017) for more on the Sisters' choice of apostolate in relation to the gender dynamics of early national Kentucky.
} 
Out of these simple origins grew the Sisters of Loretto, a congregation of women religious that eventually numbered over 1000 members, with schools and convent houses across the United States. As the country grew, and with it the number of Catholic immigrants, the Sisters of Loretto were inundated with requests for Sisters to teach in Catholic schools. They continually struggled to balance the need for rigorous training and spiritual formation of young Sisters against the increasing demand for new personnel in parish schools. This chapter will discuss the early history and growth of the Sisters of Loretto within the context of expanding Catholic education in the United States; difficulties associated with the training of Sister-teachers; and cooperation among multiple women's congregations to address these problems.

Before Rhodes, Havern, and Stuart requested Father Nerinckx's guidance in formally establishing a religious institute, the priest had tried on two occasions, unsuccesfully, to start a convent in Kentucky, because he recognized the benefit that a group of Sisters could provide to families living on the frontier. He obtained approval for the new convent from Joseph Flaget, the Bishop of Bardstown, and assisted the women in writing a rule, a document establishing the guidelines by which they would agree to live. ${ }^{57}$ The group requested that Father Nerinckx appoint one of them to act as Mother Superior, the leader of the new order, but he advised that they must choose for themselves who should fill this role. Once their membership grew larger, he advised electing leaders. ${ }^{58}$ Concerned that he would not be able to provide effective guidance for the new Sisters, Nerinckx proposed inviting some experienced women religious, from an established European order, to come to Kentucky as mentors for the new congregation.

\footnotetext{
${ }^{57}$ Ibid.

${ }^{58}$ Ibid., 27-28.
} 
Rhodes, Stuart, and Havern resisted this course of action, however, insisting that Nerinckx was the only guide they needed. When the new order, initially named the Friends of Mary at the Foot of the Cross, was formally established in 1812, it was the first fully American congregation of women religious, as it had no connection to any European order. ${ }^{59}$ The fledgling congregation sought donations locally and from abroad via Father Nerinckx, and worked to support themselves financially through school fees and weaving and spinning performed by the Sisters. Additionally, the Sisters made use of enslaved labor for tasks such as clearing land, cultivating crops, and raising livestock on their 50 acres. ${ }^{60}$ In the early years of the nineteenth century three enslaved black women sought to join the Sisters of Loretto as novices. Though the Sisters ultimately admitted the enslaved women to the congregation, they upheld the racial hierarchy of early nineteenth century Kentucky by according these women a lower status than white Sisters, and maintaining segregation. ${ }^{61}$ Shannen Dee Williams has noted that these 3 were "The first known African American women to embrace the religious state in the United States. ${ }^{.62}$

${ }^{59}$ Ibid., 30-31, 33.

${ }^{60}$ O'Daniel, Southern Veils, 48. Ann Havern transferred ownership of an enslaved man, Tom, to the congregation upon entering in 1812. By 1817, the congregation owned 10 enslaved people.

${ }^{61}$ Ibid, $144-151 . z$

${ }^{62}$ Shannen Dee Williams, "The Color of Christ's Brides," American Catholic Historian 127, no. 3 (Fall 2016), pg. 20.

Also see Joan Campbell, SL, Loretto: An Early American Congregation in the Antebellum South, (St. Louis: Bluebird Publishing, 2015).

Williams has also noted that the Sisters of Loretto are one of only three predominantly white orders of American women religious to formally apologize for their slaveholding past. See "Religious orders owning slaves isn't new - black Catholics have emphasized this history for years," America Magazine, August 6, 2019. Accessed July 16, 2020, https://www.americamagazine.org/faith/2019/08/06/religious-orders-owning-slaves-isntnew-black-catholics-have-emphasized-history. 
Once established, The Sisters of Loretto added rapidly to their membership, as young women from the surrounding area sought to join the community. As the congregation grew larger, they began to send small groups of Sisters out to establish new schools and convent houses, beginning in Kentucky and continuing westward in response to the expansion of the United States. In an article celebrating the order's history in preparation for its 200th anniversary, Loretto Magazine reported that between 1812 and 1830, the Sisters established 18 new "foundations." Between 1830 and 1900, they "founded 99 schools in territories that would become 13 different states."

Loretto membership continued to grow as the order opened and staffed schools throughout the midwestern and western United States: many new postulants were former students, attracted to the community life and educational opportunities provided to Sisters of Loretto, in addition to their religious devotion and lives of service. ${ }^{64}$ By 1917, the order was 703 members strong, with an additional 76 novices and 26 postulants in training. The Sisters provided staff for 68 schools, including 25 academies and 43 day schools, as well as faculty for Webster College, in Webster Groves, Missouri. The Sisters' second college, Loretto Heights, opened in Denver, Colorado, in $1918 .{ }^{65}$

Demand for Sister-teachers grew exponentially in the early twentieth century, as a result of the Catholic Church's teaching on religious education. At the Third Plenary Council of Baltimore, in 1884, bishops called upon American priests to open a school in

\footnotetext{
${ }^{63}$ Carolyn Dunbar, "On the Road to Jubilee: Loretto moves west from 1830 to 1900 , founding 99 schools in territories that were to become 13 different states," Loretto Magazine, Summer 2010, 18, accessed April 12, 2016, http://www.lorettocommunity.org/wp-content/uploads/2011/04/Jubilee-1830-to-1900.pdf. ${ }^{64}$ Patricia Jean Manion SL, ed. A Century of Change 1912-2012: Loretto's Second Century (Point Reyes, CA: Chardon Press, 2012), 19.

${ }^{65}$ Ibid., 20, 23.
} 
every parish in the country within two years, to ensure all Catholic children had a nearby school to attend. ${ }^{66}$ In 1897, Pope Leo XIII declared, in Militantis Ecclesiae, that "Catholics should not choose mixed schools, but have their own schools especially for children. They should choose excellent and reputable teachers for them. For an education in which religion is altered or non-existent is a very dangerous education." ${ }^{, 67}$

Though the goal of establishing a school in every parish was never realized, the Church's teaching did bring about a large increase in the number of Catholic schools. ${ }^{68}$ Bishops and parish priests called upon women religious, including the Sisters of Loretto and other teaching orders, to provide staff for existing parish schools and to establish new schools. Filling these teaching positions provided needed income for the congregation, but the constant requests for more personnel also put pressure on leadership, as the need for Sister-teachers always outpaced the number of young women entering religious life each year. ${ }^{69}$ Superiors were compelled to place new Sisters into teaching service as quickly as possible upon completion of their novitiate period.

Prior to the 1950s, the novitiate period for new Sisters of Loretto lasted approximately $2 \frac{1}{2}$ years. New arrivals were considered postulants, or candidates for religious life, for their first six months living in the convent. After completing their

\footnotetext{
${ }^{66}$ Bertrande Meyers DC, The Education of Sisters (New York: Sheed and Ward, 1941) 8, accessed April 10, 2016, http://babel.hathitrust.org/cgi/pt?id=uc1.\$b55048;view=1up;seq=7.

67 "Christian Education," http://www.catholicessentials.net/christianeducation.htm, accessed April 4, 2016.

${ }^{68}$ Dara Mulderry, "“What Human Goodness Entails: An Intellectual History of U.S. Catholic Sisters, 1930-1980. PhD diss., Brandeis University 2006, 33-34.

${ }^{69}$ Manion, A Century of Change, 19-20, 22.

Mary L. Schneider, "American Sisters and the Roots of Change: The 1950s," U.S. Catholic Historian 7, no. 1 (Winter 1988): 72. Accessed April 10, 2016, http://www.jstor.org/stable/25153816.
} 
postulancy, these Sisters were then admitted to the order as novices for two years. ${ }^{70}$

During their time as postulants and novices, new Sisters became accustomed to the daily practices of religious life, and to the strict rules which governed women religious' personal conduct and interactions. ${ }^{71}$ This period also functioned as a proving ground of sorts: a time to determine if a young woman was truly suited to religious life.

Teacher training and spiritual formation were both components of the novitiate period for new Sisters of Loretto. In 1896, the congregation established Loretto Normal School on the grounds of their Motherhouse, in order to provide formal teacher training to new members. In 1926, Loretto Normal School became Loretto Junior College, as the Sisters worked to keep pace with the increasing professional standards expected of teachers. $^{72}$

Loretto Junior College operated with extension privileges from Webster College in Missouri until 1937, when it was awarded full accreditation by the state of Kentucky. ${ }^{73}$

New members of the congregation began taking education courses as postulants. Following postulancy, however, first year novices spent a "canonical year" focused solely on spiritual formation. During this time, required by canon law, the novice suspended her teacher training to spend time in devotional reading, prayer, and

\footnotetext{
${ }^{70}$ Barbara Speas Havira and Jackie Hartman Dear, "Transitions," in Voices from Silence: A Loretto Patchwork, ed. Sandy Ardoyno et al (Nerinx, KY: Sisters of Loretto, 2012), 5. Manion, A Century of Change, 14-17.

${ }^{71}$ Havira and Dear, 7-8.

${ }^{72}$ Mulderry, "What Human Goodness Entails," 36-37.

${ }^{73}$ Manion, A Century of Change, 24.
} 
meditation, as she prepared to take her vows. ${ }^{74}$ She resumed her teacher training again as a second year novice, and went into full time teaching work the following year. ${ }^{75}$

Though a few young women entered the convent after attending college, the majority of new members entered immediately after graduating from high school. For most Loretto Sisters then, the limited college coursework completed during their novitiate period was all the training they received before being sent out to teach full time in a Catholic school. Some Sisters were barely older than their students at this point, and lacked advanced knowledge of the subject matter they were assigned to teach.

Loretto Sisters' education did not end after their novitiate period, however. In fact, they were expected to eventually complete a bachelor's degree. Because they also had to teach full time, they were forced to take evening, weekend, and summer classes, when available, on top of their teaching load. ${ }^{76}$ Compounding this difficulty was the very real possibility that Superiors might choose to change a Sister's assignment, based on the needs of the congregation and the schools they served. Most Sisters of Loretto taught and lived in several different locations over the course of their careers. With so many demands on time and energy, it often took decades for a religious to finally earn her degree -- the “twenty year plan," in Sisters' common parlance. ${ }^{77}$ Sister Helen Sanders remembered, "it took me from 1925 until 1941 to earn my A.B. and I was eager for that kind of situation to change." ${ }^{78}$ Beginning in 1912, when plans for Webster College were being formulated, some Loretto Sisters were selected for graduate studies, to enable them

\footnotetext{
${ }^{74}$ Ibid., 5.

75 Ibid.

${ }^{76}$ Mulderry, "What Human Goodness Requires, 38-39.

${ }^{77}$ Ibid., 39

${ }^{78}$ Sanders, Helen, SL. More than a Renewal. Loretto Before and After Vatican II: 1952

- 1977. (Nerinx, KY: Sisters of Loretto, 1982), 10.
} 
to teach in the new institution. ${ }^{79}$ The majority, however, who spent their careers teaching in primary or secondary schools, did not continue coursework beyond completing a bachelor's degree.

The Sisters of Loretto were not alone in the struggle to provide adequate training to their members. Sister education was a common problem among active religious orders during the early twentieth century. Most postulancy and novitiate programs were structured similarly to that of the Sisters of Loretto. Few teaching orders had the financial or personnel resources to provide four years of education for a young Sister before placing her in active service, and all faced constant pressure to fill vacancies and provide additional staff to Catholic schools. ${ }^{80}$ Because a percentage of new members typically dropped out before professing final vows, it was widely considered unwise to provide a full education before it was clear whether or not a woman would "persevere" in religious life. ${ }^{81}$ In spite of these common challenges, there was little collaboration or interaction between women's religious orders, as they tended to be quite insular organizations. ${ }^{82}$

This situation began to change during the 1940s and 50s, however, due to repeated calls for reform of Sister education programs, and increasing efforts to bring women religious from different congregations together. One of the early advocates for reform of the prevailing system of Sister education was Sister Bertrande Meyers, a member of the Daughters of Charity (DC). In her 1941 dissertation, The Education of Sisters, Meyers surveyed superiors, postulant and novice mistresses, and deans from sixty

\footnotetext{
${ }^{79}$ Dunbar, "On the Road to Jubilee: From 1900 to $1960 \ldots ., " 10$.

${ }^{80}$ Schneider, "American Sisters and the Roots of Change," 57. Mulderry, "What Human Goodness Entails,"” 35-36. Manion, A Century of Change, 19-20.

${ }^{81}$ Mulderry, “"What Human Goodness Entails," 21. ${ }^{82}$ Ibid., 81
} 
different women's religious orders throughout the United States. Her study revealed widespread inadequacies across many congregational programs of education for young Sisters. ${ }^{83}$ Meyers argued for a minimum of two full years of college coursework before entering full time apostolic service. ${ }^{84}$

In 1949, Sister Madeleva Wolff, a Sister of the Holy Cross (CSC) and president of St. Mary's College, presented a paper at the annual meeting of the National Catholic Education Association (NCEA), entitled The Education of Sister Lucy. ${ }^{85}$ Based on the work of a committee formed in 1946, at Wolff's request, to study and propose solutions to the problem of Sister education, the paper made forcefully clear how far Sisters often lagged behind their lay counterparts in teaching, as well as how widespread this problem actually was among American congregations. ${ }^{86}$ Wolff emphasized the detrimental effect of the prevailing system, on both the quality of Catholic education and the personal and intellectual development of Sisters themselves. ${ }^{87}$

Pope Pius XII bolstered the impetus for improving Sister education programs in 1951, when he gave a speech calling for excellence among Catholic religious in teaching apostolates, encouraging superiors to give them everything they needed. ${ }^{88}$ At the next gathering of the NCEA, in April 1952, Sister Mary Emil Penet, a Servant of the Immaculate Heart of Mary (IHM), proposed a coordinated course of action by American

\footnotetext{
${ }^{83}$ Meyers, The Education of Sisters, 53-54.

${ }^{84}$ Ibid., 141-211.

${ }^{85}$ The religious suffix CSC actually stands for Congregatio a Sancta Cruce, a religious order founded in France in 1837 by Blessed Basil Moreau. U.S. Sisters of the Holy Cross trace their origins to this order.

${ }^{86}$ M. Loretta Petit OP, "Sister M. Madaleva Wolff, C.S.C.," Catholic Education 9, no. 3 (March 2006): 329.

${ }^{87}$ Mulderry, "What Human Goodness Entails,"” 24.

${ }^{88}$ Joan Glisky IHM, "Sister Mary Emil Penet, I.H.M.: Founder of the Sister Formation Conference," Catholic Education 9, no. 3 (March 2006): 365.
} 
teaching orders: she recommended withholding new Sisters from teaching service until they completed college degrees, and encouraged Catholic schools to hire a percentage of lay teachers to help meet their personnel needs. Penet also recommended a survey of all American women's religious orders, to accurately gauge their educational and financial situations. ${ }^{89}$ Mary Florence Wolff, a Sister of Loretto who served on the congregation's leadership council, volunteered to be a part of this survey committee. ${ }^{90}$ The "Sister survey" proved to be a resounding success, that clearly revealed the widespread challenges shared by American religious orders devoted to the teaching apostolate.

A new multi-congregational organization, the Sister Formation Conference (SFC), formed in 1954 in response to the situation revealed by the Sister survey. "Sister Formation Conference" was chosen as the new organization's name in recognition of the unique role that Sisters played as both educators and spiritual guides. ${ }^{91}$ This role required them to have both traditional subject matter education, as well as solid theological and spiritual training. The SFC sought to integrate these goals, and to provide support and guidance to congregations as they planned for and implemented more thorough programs of Sister education and training. Sisters of Loretto played important roles in the SFC:

Florence Wolff served in SFC leadership, helping to plan yearly regional conferences that were critical to the organization's success..$^{92}$ Mary Mangan, another Sister of Loretto, also became involved, helping to formulate a model curriculum for Sisters that integrated educational goals with theological training and spiritual formation. ${ }^{93}$

\footnotetext{
${ }^{89}$ Ibid.

${ }^{90}$ Ibid.

${ }^{91}$ Ibid., 367.

${ }^{92}$ Ibid.

${ }^{93}$ Mulderry, “"What Human Goodness Entails,” 133.
} 
However, Loretto did not wait for the SFC to begin making needed changes to their own Sister education program. In July of 1952, just three months after Sister Mary Emil Penet's NCEA presentation, the order's elected representatives gathered for the annual General Chapter meeting, at which they voted on matters of congregational business. As Mother Felicitas Quinliven later wrote to bishops, pastors, and other Sisters, "The General Chapter of 1952 voted unanimously to establish a juniorate, where our young Sisters will be given the opportunity of additional spiritual formation and professional training, and legislated that no young Sister be assigned to the classroom until she has obtained her degree." 94 Quinliven informed readers that because of the Chapter's decision, the Sisters of Loretto would provide no additional teachers for the next two years, so that all current novices could first complete their bachelor's degrees. ${ }^{95}$ The "juniorate" of which Quinliven wrote was established in 1954, and came to be known as the House of Studies. ${ }^{96}$ After completing their postulancy and novitiate at the Motherhouse in Kentucky, newly professed Sisters of Loretto would move to St. Louis, where they would live in community while attending classes at Webster College to complete their degrees. $^{97}$

This change in Loretto's educational practices was accompanied by an adjustment to the period of postulancy for new Sisters. Until 1952, the congregation had accepted

Sanders, More than a Renewal, 28-29.

${ }^{94}$ Manion, A Century of Change, 25.

95 Ibid.

${ }^{96}$ Ibid., 33

${ }^{97}$ Ibid., 33-34.

Sanders, More than a Renewal, 26-32.

Helen Sanders recorded that the establishment of a Loretto juniorate had actually been brought up as early as 1946, by Mother Edwarda Boone, who preceded Mother Felicitas Quinliven as Superior General. 
new postulants at three different times each year, with each group remaining in postulancy for six months before becoming novices. As Helen Sanders pointed out in her memoir, More Than a Renewal, "It had always been difficult to build a satisfactory teacher preparation program around those limits of time and required preparation for vows. ${ }^{98}$ Beginning in 1953, the congregation accepted new postulants only once each year, in September, and extended the postulancy period to $8 \frac{1}{2}$ months, to allow new members more time for their coursework and spiritual formation. ${ }^{99}$

The Church seemed to affirm these changes when, soon after the momentous General Chapter meeting of July of 1952, Mother Felicitas Quinliven was called to Rome to attend a meeting of major superiors of women's religious orders. Father Larraona, Prefect of the Sacred Congregation of Religious, described the meeting as part of a larger "movement...a sincere effort to keep pace with the times." ${ }^{100}$ Church leaders, including the Pontiff, encouraged women religious to bring their way of life "up to date," and to see that members received excellent training for their apostolates, to ensure that young women would not be discouraged from entering the convent. ${ }^{101}$

Helen Sanders, who accompanied Quinliven on this trip to Rome, reported that one of the major results of the superiors' meeting was the establishment of another important organization: the Conference of Major Superiors of Women (CMSW). The goal of this new organization was to foster more open communication and greater collaboration among different congregations of women religious. ${ }^{102}$ Sanders and three

\footnotetext{
${ }^{98}$ Sanders, More than a Renewal, 17.

${ }^{99}$ Ibid., 18.

${ }^{100}$ Ibid., 25.

${ }^{101}$ Ibid., 5.

102 Ibid., 5-6.
} 
other Sisters of Loretto were present at the first organizational meeting of the CMSW, which took place in 1956. Mother Felicitas Quinliven served the CMSW as chairperson of the organization's southern region. ${ }^{103}$ Quinliven's successor as Loretto's Superior General, Mary Luke Tobin, was elected president of the CMSW. In this capacity, Tobin was invited, in 1964, to attend the third and fourth sessions of the Second Vatican Council as an official auditor. She was one of only a few women permitted to attend the Council, and the only American woman invited. Because of her role as an auditor, Tobin also participated in "the planning commissions for the preparation of documents -- one on the church in the modern world and one on the laity". ${ }^{104}$

The Sisters of Loretto embraced the momentum of change among congregations of women religious in the 1950s. Recognizing the need for more robust training of Sisterteachers, the community acted decisively in updating their own program, and collaborated broadly through the new multi-congregational organizations formed to help address common challenges. These efforts to provide high quality education and spiritual formation to their members brought the Sisters of Loretto into contact with emerging ideas in Catholic theology. The Sisters' engagement with these emerging ideas, denoted nouvelle théologie by detractors, became an important factor in the coming years, underlying many of the choices the congregation would make regarding changes to their traditional way of life. The key ideas of nouvelle théologie will be the subject of the next section.

${ }^{103}$ Ibid., 6.

${ }^{104}$ Mary Luke Tobin, Hope is an Open Door (Nashville: Abingdon, 1981), 21. 


\section{NOUVELLE THÉOLOGIE: HISTORICAL BACKGROUND, KEY IDEAS, AND IMPACT ON THE SECOND VATICAN COUNCIL}

From the late nineteenth century to the time of the Second Vatican Council, 1962 - 1965, Catholic theology was dominated by Neo-scholasticism: a tightly controlled system of theological thought that rejected the ideas of modern science, philosophy, and Biblical criticism in favor of the teachings of St. Thomas Aquinas, a thirteenth century Dominican monk. Beginning in the 1930s, however, a group of French theologians began to be critical of Neo-scholasticism, arguing that it had rendered theology an almost entirely academic endeavor, unconnected with the life experiences of Catholic parishioners. They advocated for changes in Catholic theology and practice aimed at reconnecting the faith with the modern world and with Church members' everyday lives. Ultimately they believed these changes would help to facilitate a renewal of religious faith within an increasingly secular French society. The ideas promoted by this group of scholars became known as nouvelle théologie.

After being suppressed by Church authorities throughout much of the 1950s, the ideas of nouvelle théologie gained much wider acceptance at the Second Vatican Council. Because many of the movement's participants, the nouveaux théologiens, participated in the Council as theological advisers, their ideas are evident in the documents produced by the Council, which brought about significant changes in Catholic life. In this section, I will discuss the historical context in which nouvelle théologie developed, the main 
differences distinguishing it from the prevailing Neo-scholastic theology, and its impact on the documents of the Second Vatican Council.

Nouvelle théologie first arose in France during the interwar period as a critique of Neo-scholasticism -- the rationalist, juridical system of theological thought that had dominated Catholic scholarship since the late nineteenth century. Though the movement eventually grew to include Belgian, German, and Dutch scholars, it was initially associated with two groups of French priests -- Dominican fathers, including MarieDominique Chenu and Yves Congar; and Jesuit fathers, including Henri de Lubac, Jean Danièlou, and Henri Bouillard. ${ }^{105}$

As theologian Jurgen Mettepenningen attests, nouvelle théologie is challenging to define, due to the broad range of unique topics and subfields in which the nouveaux théologiens specialized, as well as the fact that some of these scholars resisted identifying themselves with nouvelle théologie, at times even denying that such a "movement" existed. ${ }^{106}$ The nouveaux théologiens did not view their work in this way, nor did they have any formal association, though some were friends, correspondents, or colleagues. In Nouvelle Théologie and Sacramental Ontology: A Return to Mystery, Hans Boersma

\footnotetext{
${ }^{105}$ Gabriel Flynn, "Introduction: The Twentieth-Century Renaissance in Catholic Theology," in Ressourcement: A Movement for Renewal in Twentieth-Century Catholic Theology, ed. Gabriel Flynn and Paul D. Murray (Oxford: Oxford University Press, 2012), 1 .

${ }^{106}$ Christopher Ruddy, "Ressourcement and the Enduring Legacy of Post-Tridentine Theology," in Ressourcement: A Movement for Renewal in Twentieth-Century Catholic Theology, ed. Gabriel Flynn and Paul D. Murray (Oxford: Oxford University Press, 2012), 186. Mettepenningen, Nouvelle Théologie, 7-8.
} 
asserts that in challenging one school of thought, Neo-scholasticism, the nouveaux théologiens were not seeking to establish an alternate system. ${ }^{107}$ Rather, the ideas they promoted were aimed at reconnecting Catholic theology with the lived experience of parishioners, bringing about reform and renewal in Catholic life.

Neo-scholasticism, the theological system criticized by the nouveaux théologiens, became the official position of the Church during the late nineteenth and early twentieth centuries, in the midst of the Modernist Crisis. During this time, emerging ideas in the sciences, in history, and in philosophy posed challenges to traditional Church teachings about the origins of life, proper understanding of the Bible, the immutability of doctrine, human nature, and sin. Such modernist ideas, as they were labeled, prompted a reactionary response from Catholic Church officials, who viewed them as a threat to Christianity, against which they must be on guard. In response to the spread of modernist ideas, Catholic theologians renewed emphasis upon Scholastic theology -- the teachings of the medieval scholar Saint Thomas Aquinas. ${ }^{108}$

Writing in the thirteenth century, Aquinas attempted to reconcile Christian thought with the classical philosophy of Aristotle, whose works had been recently reintroduced into western Europe. ${ }^{109}$ In his landmark work Summa Theologiae, he "tried to

\footnotetext{
${ }^{107}$ Hans Boersma, Nouvelle Théologie and Sacramental Ontology: A Return to Mystery (Oxford: Oxford University Press, 2009), Kindle edition, location 203.

${ }^{108}$ Fergus Kerr, Twentieth Century Catholic Theologians (Malden, MA: Blackwell Publishing, 2007), 1.

${ }^{109}$ Ibid., 28
} 
systematically present all theology in a unified whole, with moral theology or ethics as a part of this whole."110 Aquinas's works had experienced a prior revival of scholarly interest, during the sixteenth and seventeenth centuries (referred to by some nouveaux théologiens as "Baroque Scholasticism"). ${ }^{111}$ Baroque Catholic scholars produced a number of commentaries on the work of St. Thomas, which bore significant influence on later studies: the commentaries written by Thomas Cardinal Cajetan (completed 1522) and Francisco Suárez (published 1590 - 1620), for example, continued to impact interpretation of Aquinas's work centuries later. ${ }^{112}$ Aquinas scholars of the late nineteenth and early twentieth centuries, who were known as Neo-Scholastics or NeoThomists, turned to his work as an antidote to the perceived heresies of modernism. ${ }^{113}$ Neo-Scholastics defined themselves in opposition to modernism, and focused their work

Charles E. Curran, Catholic Social Teaching 1891 - Present: A Historical, Theological, and Ethical Analysis (Washington, D.C.: Georgetown University Press, 2002), 3-4. ${ }^{110}$ Ibid., 3.

${ }^{111}$ Stephen M. Fields, SJ, "Ressourcement and the Retrieval of Thomism for the Contemporary World," in Ressourcement: A Movement for Renewal in TwentiethCentury Catholic Theology, ed. Gabriel Flynn and Paul D. Murray (Oxford: Oxford University Press, 2012), 355.

Kerr, Twentieth Century Catholic Theologians, 22.

Ruddy, "Ressourcement and the Enduring Legacy of Post-Tridentine Theology," in Ressourcement: A Movement for Renewal in Twentieth-Century Catholic Theology, ed. Gabriel Flynn and Paul D. Murray (Oxford: Oxford University Press, 2012) 186.

${ }^{112}$ As an example, Father Henri de Lubac, in Surnaturel, considered Cajetan and Suarez to be primarily responsible for the then-orthodox interpretation of St. Thomas that insisted upon a sharp division of the natural from the supernatural -- a position he considered to be an incorrect reading of St. Thomas, with harmful implications for Catholic spiritual life. See Boersma, Nouvelle Theologie, Kindle edition, location 12851305.

${ }^{113}$ Kerr, Twentieth Century Catholic Theologians, 1. Mettepenningen, Nouvelle Théologie, 18-19. 
on the critique of modernist ideas using the teachings of St. Thomas. ${ }^{114}$ As Jurgen Mettepenningen describes the situation, "by its being employed as a weapon in the fight against Modernism, neo-scholasticism ultimately became anti-modern."

In this defensive environment, Neo-Scholasticism gradually became the normative theological position of the Church. ${ }^{116}$ It gained public papal support in 1879 , when Leo XIII released an encyclical entitled Aeterni patris, in which he called for a return to Thomistic teachings. ${ }^{117}$ In the same year, the Vatican also supported the establishment of a new institution in Rome devoted to St. Thomas's teachings: the Pontifical Academy of St. Thomas Aquinas. ${ }^{118}$ Neo-scholasticism had become even more firmly entrenched by the early twentieth century: Leo XIII's successor, Pius X published two documents in 1907, the papal decree Lamentabili sane exitu and the encyclical Pascendi dominici gregis, in which he roundly condemned key modernist ideas, and warned of the alleged danger they posed to Catholic life. ${ }^{119}$ He went further in 1910 ,

\footnotetext{
${ }^{114}$ Ibid, 24.

115 Ibid.

${ }^{116}$ Ibid.

117 John O'Malley, What Happened at Vatican II (Cambridge, MA: Harvard University Press, 2008), 62.

118 "Pontifical Academy of St. Thomas Aquinas," The Vatican, http://www.vatican.va/roman curia/pontifical academies/san-tommaso/index.htm, accessed May 19, 2016.

${ }^{119}$ Gerard Loughlin, "Nouvelle Théologie: A Return to Modernism?" in Ressourcement: A Movement for Renewal in Twentieth-Century Catholic Theology, ed. Gabriel Flynn and Paul D. Murray (Oxford: Oxford University Press, 2012), 38.

English translation of Lamentabili sane exitu available at: http://papalencyclicals.net/Pius10/p10lamen.htm.
} 
demanding conformity from all Catholic clergy, religious superiors, and teachers in Catholic seminaries by requiring them to sign an anti-modernist oath, affirming that they rejected the tenets of modernist thought and promising to guard those under their pastoral care or tutelage from falling into these perceived errors. ${ }^{120}$ By 1917 , Neo-Scholasticism had become an official element of Church teaching: the new Code of Canon Law stipulated that Thomist philosophical and theological principles be taught in all Catholic seminaries. ${ }^{121}$

In addition to establishing Neo-Scholasticism as the only acceptable form of theological teaching, its proponents also actively undertook to find and expose any hints of modernism within the Church. Monsignor Umberto Benigni led the Sodalitium Pianum, a network of anti-modernist informants, who would report back to him any evidence of modernism or modernist sympathy within the Church. ${ }^{122}$ Many Catholic scholars who ascribed to modernist ideas (or who simply did not oppose modernism strongly enough) found themselves accused of heresy, removed from university teaching positions, their writings placed on the Index Librorum Prohibitorum, the Index of Forbidden Books. ${ }^{123}$ One of the best known clergy to feel the full weight of Church discipline on this issue was the Irish Jesuit George Tyrrell, excommunicated in 1908 for

English translation of Pascendi domenici gregis available at: http://www.papalencyclicals.net/Pius10/p10pasce.htm.

${ }^{120}$ Loughlin, “"Nouvelle Théologie: A Return to Modernism?” 38.

${ }^{121}$ Mettepenningen, Nouvelle Théologie, 24.

${ }^{122}$ Ibid., 25.

${ }^{123}$ Ibid., 22-23. 
his defense of modernist ideas, and for his open criticism of Lamentabili sane exitu and Pascendi dominici gregis the prior year. ${ }^{124}$ Another notable scholar to face discipline was Alfred Loisy, who was removed from his professorship at Institut Catholique de Paris in 1893 due to his support for application of historical-critical methods to the study of Scripture. Like Tyrell, Loisy was also excommunicated in $1908 .{ }^{125}$ A slightly later example, Father Pierre Teilhard de Chardin, entered the Jesuit order in 1899 , and signed the required Anti-Modernist Oath in $1910 .{ }^{126}$ After completion of his theological training and service in the First World War, he went on to an academic career, pursuing scientific studies, and eventually became a highly regarded paleontologist. ${ }^{127}$ However, Teilhard spent the majority of his career working in China, due to the controversy created by his teaching on evolution at the Institut Catholique de Paris in the early 1920s. ${ }^{128}$ Though he wished to return permanently to his native France, following the end of World War II, his Jesuit superiors refused permission for him to accept a faculty post at the Sorbonne. ${ }^{129} \mathrm{He}$ was forced to spend the final years of his life

\footnotetext{
${ }^{124}$ Kerr, Twentieth Century Catholic Theologians, 5-7. Mettepenningen, Nouvelle Théologie, 24.

${ }^{125}$ Boersma, Nouvelle Théologie, Kindle edition, location 320-333. Mettepenningen, Nouvelle Théologie, 23.

${ }^{126}$ John Grim and Mary Evelyn Tucker, "Biography," American Teilhard Association, accessed August 3, 2016, http://teilharddechardin.org/index.php/biography.

David Grummett, "Teilhard at Ore Place, Hastings," New Blackfriars 90, no. 1030 (November 2009): 692, accessed August 3, 2016, http://www.jstor.org/stable/43251348.

${ }^{127}$ Ibid.

128 Ibid.

${ }^{129}$ Ibid.
} 
working for the Wenner-Gren foundation in New York, where he passed away in $1955 .{ }^{130}$ Though Teilhard published scientific work throughout his life, he was forbidden to pursue theological work after 1928, leaving much of his work to be published posthumously by lay friends. ${ }^{131}$

The normalization of neo-Scholasticism by Church authorities, as well as their aggressive efforts to quash dissenting opinions, led to the development of an extremely rigid, tightly controlled environment within Catholic seminaries, in which orthodoxy, rather than exploration, was the focus of learning. Students were rarely encouraged to engage directly with Aquinas's work, or any other primary sources. ${ }^{132}$ Teaching was typically done using manuals or handbooks, based on 24 Vatican-approved Thomistic theses that were considered to form the essential core of his philosophy, or textbooks and commentaries on Aquinas, written hundreds of years after his lifetime. ${ }^{133}$ When original sources were engaged with, Neo-scholastic scholars employed what Gerald O'Collins, a Jesuit scholar, refers to as "the regressive method:" "Manualist theologians read the sources but only in light of what was currently taught and believed, and with the intention

\footnotetext{
${ }^{130}$ Ibid.

${ }^{131}$ Ibid.

${ }^{132}$ Kerr, Twentieth Century Catholic Theologians, 9.

${ }^{133}$ Ibid, 3-5, 9-10.
} 
of defending what came from the official teaching authority of the church and, in particular, from the pope of the time."134

The writings of Church fathers earlier than or contemporary to Thomas Aquinas were also rarely studied, as Aquinas's work was considered to be the pinnacle of Catholic theological thought. ${ }^{135}$ Dominican scholar Fergus Kerr describes the Neo-Scholastic position in this way: “...Thomas Aquinas’s work -- chiefly the Summa Theologiae -- was an unsurpassed and unsurpassable speculative theological achievement. It might, and indeed should, be studied in the light of the clarifications offered by a select band of sixteenth-century commentators. There was, however, no point in paying much attention to how his thought interacted with that of his contemporaries or how it was shaped by his inheritance from earlier Christian thinkers (let alone Jewish or Muslim ones)." ${ }^{136}$ This system was firmly entrenched by 1920, and remained dominant through the 1950 s.

Beginning in the 1930s, however, Dominican fathers Marie-Dominique Chenu and Yves Congar, along with Louis Charlier and Henri-Marie Feret, began to write critically about Neo-scholasticism. They advocated for changes in Catholic theological teaching and practice, aimed at bringing about a renewal in religious life. ${ }^{137}$ The Jesuits Henri de Lubac, Jean Daniélou, and Henri Bouillard rose to prominence during the

\footnotetext{
${ }^{134}$ Gerald O'Collins, "Ressourcement and Vatican II," in Ressourcement: A Movement for Renewal in Twentieth-Century Catholic Theology, ed. Gabriel Flynn and Paul D. Murray (Oxford: Oxford University Press, 2012), 375.

${ }^{135}$ Kerr, Twentieth Century Catholic Theologians, 10-11.

${ }^{136}$ Ibid., 11, 18.

${ }^{137}$ Mettepenningen, Nouvelle Théologie, 30-33.
} 
1940s, and continued the critique of Neo-scholasticism as they recommended changes in practice in order to foster religious renewal. ${ }^{138}$ The movement became more international during the 1950s, with contributions from Dutch fathers including Edward Schillebeekx and Piet Schoonenberg, and Germans such as Karl Rahner and Hans Urs von Balthasar. ${ }^{139}$

A primary call of the nouveaux théologiens was for ressourcement -- a return to the original documentary sources of Christian inspiration. ${ }^{140}$ They objected to the "handbook" method of theological teaching then practiced in Catholic seminaries, and to the common practice among Catholic scholars of basing their theological conclusions on commentaries written in the 16th and 17th centuries. The nouveaux théologiens believed that these methods often distorted the meanings of the original texts. ${ }^{141}$ They advocated for a renewed emphasis on direct engagement with original sources, including the Scriptures and the work of Thomas Aquinas himself, instead of relying on commentators such as Cajetan and Suarez. ${ }^{142}$ Additionally, many nouveaux théologiens studied the works of other early and medieval church fathers, such as Irenaeus, Origen, and Gregory of Nyssa, a body of literature largely ignored by the Neo-scholastics. They believed that

\footnotetext{
${ }^{138}$ Ibid., 33-35.

${ }^{139}$ Ibid., 36.

${ }^{140}$ Ibid., 11

${ }^{141}$ Ibid.

${ }^{142}$ Ibid.
} 
the writings of these scholars could also contribute to a more comprehensive understanding of Catholic theology. ${ }^{143}$

Their call for ressourcement complemented the nouvelle théologiens' desire to incorporate history into the study of theology, "to restore to theology a sense of historical development." 144 Jurgen Mettepenningen writes that, "Up to this juncture, history had tended to take second place to theology's abstractions, theories and speculations...history was only given a place when it suited accepted Catholic theology. In practice, this implied that theologians took dogmas and other Roman texts as their point of departure, arriving at new faith insights by way of deduction that were completely compatible with existing and familiar tenets of the faith."

For the nouveaux théologiens, Neo-scholasticism's disregard for historical context also had a distortionary effect on the practice of theology, by completely separating it from actual lived experience. As Mettepenningen puts it, "Those who refused to integrate history into the practice of theology were ultimately adherents of a meta-historical system rather than an incarnated faith." 146 For this reason, Catholic theology as practiced by the Neo-scholastics seemed to them to have become largely an academic exercise: "a form of philosophical metaphysics in which the conceptual system took pride of place to the

\footnotetext{
${ }^{143}$ Boersma, Nouvelle Théologie, Kindle edition, location 129-136.

${ }^{144}$ Ibid., location 136.

${ }^{145}$ Mettepenningen, Nouvelle Théologie, 10.

146 Ibid.
} 
relationship between theology, faith and life," having few implications, if any, for the day-to-day lives of Catholic parishioners. ${ }^{147}$

The nouveaux théologiens believed that this faith/life rupture also stemmed from Neo-scholastic teaching on the relationship of nature and grace, or nature and the supernatural. ${ }^{148}$ Neo-scholasticism insisted upon a sharp divide between the natural world and the supernatural, viewing these as two distinct and separate realms. ${ }^{149}$ Human beings, though created by God, were of the natural realm, with no innate knowledge of or inclination toward God. Revelation of Divine truth came from the supernatural, as did the faith to receive it, both extrinsic gifts of grace. ${ }^{150}$ By contrast, as Hans Boersma writes, "The nouveaux théologiens were convinced that God had created the human person with a supernatural end, so that the supernatural was not a strictly extrinsic divine imposition on nature. Such a separation of nature and the supernatural would render the realm of nature (as well as people's day-to-day lives) strictly autonomous or secular, while theology and faith would become privatized and disconnected from life in the natural realm."

Boersma considers the desire to reconnect the natural with the supernatural to be at the heart of nouvelle théologie, because only in this way could Catholic theology

\footnotetext{
${ }^{147}$ Ibid., 11.

${ }^{148}$ Boersma, Nouvelle Théologie, Kindle edition, location 156-167.

${ }^{149}$ Ibid, location 157-159.

150 Ibid.

${ }^{151}$ Ibid., location 163-165.
} 
meaningfully engage with the issues and experiences of modern life. ${ }^{152}$ This perceived need for engagement with the modern world, for renewed relevance, represented the core reason behind the criticisms of Neo-scholasticism leveled by the nouveaux théologiens. They sought to restore to Catholic theology and practice a vitality they felt had been lost as the Church, over time, became increasingly focused on the protection of orthodoxy and authority, and the elimination of alleged heresy. In so doing, it failed to address the life experiences of rank and file Catholic parishioners, or the larger political, economic, and social issues that impacted them. The nouveaux théologiens believed that this was theology's primary duty. They saw Neo-scholasticism's failure in this regard as contributing to a decline in participation in religious activities, and growing secularization in France, which they observed particularly among the working classes. ${ }^{153}$

The nouveaux théologiens' willingness to openly critique accepted theological ideas and practices generated controversy from their earliest publications, as prominent Neo-scholastic scholars voiced objections to their ideas. The moniker nouvelle théologie actually originated in this context, applied as a pejorative by the movement's detractors. Though seen in print as early as 1942, the term was most famously used by Father Reginald Garrigou-LaGrange, a Dominican scholar. In 1946, he published an article in the Catholic theological journal Angelicum, entitled "La nouvelle théologie où va-t-elle?"

\footnotetext{
${ }^{152}$ Ibid., location 161-163.

${ }^{153}$ Boersma, Nouvelle Théologie, Kindle edition, location 162-163. Jean-Marie Domenach and Robert de Montvalon, The Catholic Avant-Garde: French Catholicism Since World War II, trans. Brigid Elson, Jacqueline Pace, Irene Uribe, and Frances Wilms (New York: Holt, Rinehart and Winston, Inc., 1967) 48-52.
} 
("Where is the new theology leading us?"). ${ }^{154}$ In the article, Garrigou-LaGrange sharply criticized the ideas of several contemporary writers and thinkers, including Father Henri Bouillard, Father Henri de Lubac, and the lay Catholic philosopher Maurice Blondel. He declared that they were heretical -- nothing more than "modernism" re-born. ${ }^{155}$

Such accusations resulted in disciplinary action against many of the nouveaux théologiens: Dominicans Yves Congar and Marie-Dominique Chenu both faced internal censure from their order from the late 1930s, and Chenu's manuscript, Une École de théologie: Le Saulchoir, was placed on the Vatican's infamous Index of Forbidden Books. ${ }^{156}$ The controversy quieted to a degree after the outbreak of the Second World War, as publication necessarily slowed. Congar and others served in the military, while Jesuit Father Henri de Lubac participated in the Resistance, against the wishes of his Jesuit superiors. ${ }^{157}$ Publication resumed following the liberation of France, however, with de Lubac in particular publishing a large volume of material that he had continued to work on during the war. ${ }^{158}$

${ }^{154}$ Fr. Reginald Garrigou-LaGrange, OP, "Where is the New Theology Leading Us?" Translated by Suzanne M. Rini. Catholic Family News 309 (August 1998), 1-3. Accessed April 19, 2016, https://archive.org/stream/Garrigou-

LagrangeEnglish/ Where\%20is\%20the\%20New\%20Theology\%20Leading\%20Us \%2 0-\%20Garrigou-Lagrange $\% 2 \mathrm{C} \% 20$ Reginald $\% 2 \mathrm{C} \% 20 \mathrm{O} . \mathrm{P}$ _ djvu.txt.

${ }^{155}$ Ibid., 7.

${ }^{156}$ Boersma, Nouvelle Théologie, Kindle edition, location 364-384. Kerr, Twentieth Century Catholic Theologians, 19-20, ${ }^{157}$ Ibid., 35, 70 Mettepenningen, Nouvelle Théologie, 96

${ }^{158}$ Ibid. 
As the nouveaux théologiens continued to challenge Neo-scholastic norms, the work of de Lubac and others quickly came under attack by Church authorities. Jean Daniélou was forced to resign as editor of the journal Études in 1946, shortly after publishing an article, "Les orientations de présentes de la pensée religieuse," which was openly critical of Neo-scholasticism. ${ }^{159}$ In 1950, Henri de Lubac was also forced out of an editorial position, at the Jesuit journal Recherches de science religieuse. ${ }^{160}$ The same year, de Lubac and several others were removed from teaching positions and ordered by their Jesuit superiors to leave Lyon. They also saw a number of their books and articles removed from circulation in Jesuit libraries. ${ }^{161}$

Soon after this, Pope Pius XII issued the encyclical Humani generis (The Human Race), condemning many of the ideas put forth by the nouveaux théologiens, in "Rome's final serious defence of neo-scholasticism as a normative framework determining the orthodoxy of theology."162 The Dominicans Congar and Chenu soon received punishments similar to their Jesuit confreres: both faced internal discipline from their order in 1953 for their involvement with the "worker priest" movement, an effort to evangelize the increasingly secular working classes by obtaining factory jobs and

${ }^{159}$ Mettepenningen, Nouvelle Théologie, 89-92, 95.

Boersma regards this article as a programmatic statement for nouvelle théologie. See Boersma, Nouvelle Théologie, Kindle edition, location 122-155.

${ }^{160}$ Mettepenningen, Nouvelle Théologie, 111.

${ }^{161}$ Ibid., 111-112.

162 Ibid., 35. 
working among them. ${ }^{163}$ While Chenu had not been allowed to teach at Le Saulchoir, the Dominican study house, since 1936, Congar was removed from his teaching post there in 1953, and was "forbidden to set foot in any study house of the Dominican Order."

Church suppression of nouvelle théologie continued throughout much of the 1950s, making this a lonely and difficult decade for many of the movement's scholars. ${ }^{165}$ Many lived some type of exile, sent away from the institutions in which they had taught, out of favor with their religious orders, and unable to preach or publish, in some cases. Yves Congar, for example, spent time in Jerusalem, Rome, and Cambridge after being sent away from Le Saulchoir. ${ }^{166} \mathrm{He}$ was finally able to settle in Strasbourg, when he received an invitation from the sympathetic local bishop. ${ }^{167}$ Congar later remembered his six month exile in Cambridge as the worst period of his life: more difficult even than his years in a German prison during World War II. ${ }^{168}$

The situation began to change in 1959, however. Pope Pius XII, a staunch opponent of nouvelle théologie, passed away the prior year, and the newly elected Pope John XXIII surprised the world by announcing that he intended to convene a full-scale ecumenical council a gathering of the Church's entire ecclesiastical hierarchy, in order to

\footnotetext{
${ }^{163}$ Kerr, Twentieth Century Catholic Theologians, 20, 36.

164 Ibid., 36.

${ }^{165}$ Boersma, Nouvelle Théologie, Kindle edition, location 358.

${ }^{166}$ Kerr, Twentieth Century Catholic Theologians, 36.

${ }^{167}$ Ibid.

168 Ibid.
} 
"reaffirm doctrine and discipline." 169 It had been nearly a century since the First Vatican Council met - the last time such a gathering had taken place. Also surprising, as historian John O'Malley, SJ points out, was the pontiff's departure from the typically negative, warning tone of papal communications. Instead, he framed his reasons for convoking the Council in generally positive terms, expressing a desire for the upcoming Council "to promote 'the enlightenment, edification, and joy of the the entire Christian people,' and...to extend 'a renewed cordial invitation to the faithful of the separated communities to participate with us in this quest for unity and grace, for which so many souls long in all parts of the world." ${ }^{\prime 170}$

The Council was set to open in Rome during the fall of 1962, following a three year period of preparation. ${ }^{171}$ During this time, the Vatican first sought the input of all the bishops and other Church officials as to what concerns they wished to see addressed by the Council. ${ }^{172}$ Once their responses had been compiled, ten preparatory committees, for the most part corresponding to one of the Congregations of the Curia (Vatican bureaucratic offices) began working "to produce documents to be submitted to the council for ratification," using the compiled input of the bishops as their guide. ${ }^{173}$ The preparatory committees were headed by cardinals, and comprised of bishops, priests, and

\footnotetext{
${ }^{169}$ Ibid., 37, 151.

John O'Malley, What Happened at Vatican II (Cambridge, MA: Harvard University Press, 2008), 16-17.

${ }^{170}$ Ibid., 17.

${ }^{171}$ Ibid., 19, 21.

172 Ibid., 19-20.

173 Ibid., 20-21.
} 
other church officers, who were full voting members, as well as periti ("consultors"), who did not vote, but could offer guidance as the draft documents took shape ${ }^{174}$ Once the Council opened, the documents (referred to as "schema") prepared by the committees were "presented, discussed, emended, and voted on" during working sessions, also referred to as General Congregations. ${ }^{175}$ Periti continued to play an important role after the Council opened: almost 500 periti were officially appointed to provide theological consultation to the nearly 2500 council fathers in attendance. ${ }^{176}$ Additionally, some of the council fathers brought a theologian with them to provide assistance. ${ }^{177}$

Quite unexpectedly, given the suppression of nouvelle théologie throughout the preceding decade, several notable scholars associated with the movement were invited to serve as periti, both in the preparatory period, and at the Council: some as appointees of the Vatican, some as personal advisors to individual Bishops in attendance. ${ }^{178}$ Fathers Yves Congar, Henri de Lubac, Jean Daniélou, Karl Rahner, Joseph Ratzinger (later Pope Benedict XVI), and others, exerted significant influence on the direction of the Council, as they advised during debates and helped to draft and emend Council documents on the role of the Church, religious communities, and other issues. ${ }^{179}$ Though a small, but

\footnotetext{
174 Ibid.

175 Ibid., 24.

176 Ibid., 23

177 Ibid.

${ }^{178}$ Mettepenningen, Nouvelle Théologie, 36. Boersma, Nouvelle Théologie, Kindle edition, location 358.

${ }^{179}$ Ibid.

O’Malley, What Happened at Vatican II, 43.
} 
powerful, minority of Council Fathers objected to any proposed changes in Catholic practice, the ideas of the nouveaux théologiens were given serious consideration at the Council. They gained broad acceptance among the assembled Bishops, as demonstrated by the promulgated documents. ${ }^{180}$

Gerald O'Collins, in his essay “Ressourcement and Vatican II," points in particular to Perfectae Caritatis ("of perfect charity"), the document on renewal within religious orders, and Optatam Totius ("desired renewal of the whole [church]"), the document addressing the education of priests, as examples. ${ }^{181}$ Both documents echo the call of the nouveaux théologiens for ressourcement, encouraging both priests and religious to have greater contact with the Scriptures. ${ }^{182}$ Priests are advised to study Biblical languages in order to read the original texts, "free...from the sometimes misleading medium of translation," and religious men and women are advised to return to the original inspiration of their order's founder/foundress. ${ }^{183}$ At the same time, religious orders are also encouraged to make necessary adaptations to their way of life, to better engage, "'the changed conditions of the times," reflecting the nouveaux theologiens" concern for Church engagement with the issues of modern life. ${ }^{184}$

\footnotetext{
${ }^{180}$ Ibid., 43, 108-114. O'Collins, "Ressourcement and Vatican II," 372-374, 378-391.

${ }^{181}$ O'Collins, "Ressourcement and Vatican II," 373.

182 Ibid.

183 Ibid. .

${ }^{184}$ Ibid.
} 
O’Collins also offers helpful analysis of the Council documents Dei Verbum ("God's word"), on the sources of revelation; Lumen Gentium ("light of the nations"), the Dogmatic Constitution of the Church; and Ad Gentes ("to the nations"), the document on the missionary activity of the Church, revealing further influence of the nouveaux théologiens. ${ }^{185}$ Dei Verbum, the primary theological statement of the Council, was the subject of much debate by the Council Fathers, and went through numerous revisions before final approval in 1964. ${ }^{186}$ Jean Daniélou, Karl Rahner, Joseph Ratzinger, and Pieter Smulders were among the nouveaux théologiens who influenced this document's formation as they worked on its drafts. ${ }^{187}$ Dei Verbum reflects their concern for ressourcement in its "profoundly Biblical orientation," encouraging thorough study of Scripture by both clergy and, importantly, the laity: "Here the Council dreamed of the whole church being nourished by the Bible at every level of its existence. A prayerful knowledge of the scriptures would foster among all the baptized a living union with Christ and a life centered on him and blessed by the Holy Spirit." 188

By centering the Scripture as a vital source of faith and encouraging lay engagement and application of its teachings, Dei Verbum also reflects nouvelle théologie's concern that Catholic theology address the everyday lives of Catholic parishioners. This focus is further evident in the document's interpretation of divine

\footnotetext{
185 Ibid., 379-391.

${ }^{186}$ Ibid., 381.

${ }^{187}$ Ibid.

${ }^{188}$ Ibid., 384-385.
} 
revelation, "as primarily the personal self-revelation of the triune God in Christ, who invites human beings to enter freely into a dialogue of love. As an interpersonal event, revelation evokes a response of faith, understood as a personal commitment of the whole human being inspired by the Holy Spirit." ${ }^{\prime 189}$ This dynamic, relational understanding of revelation and faith represents a distinct departure from the Neo-scholastic emphasis on faith as an "intellectual assent" to a list of propositional truths about God, and of revelation as limited to the past. ${ }^{190}$ In support of this view, peritus Joseph Ratzinger and Pieter Smulders appealed to the teachings of medieval Church fathers St. Bonaventure and St. Hilary of Poitiers, in keeping with their efforts at ressourcement. ${ }^{191}$ Ressourcement of medieval church fathers is also evident in Lumen Gentium, the Council's teaching on the nature of the Church. Father Yves Congar played a role in drafting and revising this document, and O'Collins points to his influence particularly in Chapter 1, which presents the "sacramental reality" of the Church. ${ }^{192}$ Congar supports this understanding of the Church, as "the sign and instrument of intimate communion with God and of unity among the whole human race,"' by appealing to both Biblical imagery and the teachings of Church fathers. ${ }^{193}$ In another departure from Neo-scholastic teaching, this idea of the Church is not simply equated with the Roman Catholic

\footnotetext{
${ }^{189}$ Ibid., 382.

${ }^{190}$ Ibid.

${ }^{191}$ Ibid., 380-383.

192 Ibid., 386.

193 Ibid.
} 
Church. ${ }^{194}$ Instead, Lumen Gentium recognizes and affirms the "'elements of sanctification and truth'...found outside the 'structure of the' Roman Catholic Church," reflecting an ecumenism in keeping with nouvelle théologie's concern for increased engagement with the modern world. ${ }^{195}$

Catholic laity figure importantly in Lumen Gentium, particularly in Chapter 4, developed largely by Gérard Philips. ${ }^{196}$ This chapter addresses the topic of Christ's threefold office, of prophet/teacher, priest, and king/shepherd. Departing from Neoscholastic emphasis on the hierarchical structure of the Church, it teaches that these roles are applicable to both clergy and laity ("all the baptized"). ${ }^{197}$ In this way, Lumen Gentium further reflects nouvelle théologie's concern for relevance to the lives of Catholic parishioners, as it makes them full participants in the work of Christ and the Church.

O'Collins also points to Ad Gentes, the Council document on the missionary activity of the Church, as reflective of nouvelle théologie's concerns, through the particular influence of Yves Congar. In keeping with ressourcement, the document appeals both to Scriptural references and to the teachings of medieval theologians Irenaeus and Augustine, among others, to show that Christ ("the Word") has been present in creation since the beginning of history, "revealing the Father to human beings" through the created order. This "universal divine activity," is regarded as a "preparation" for the

\footnotetext{
194 Ibid.

195 Ibid.

${ }^{196}$ Ibid., 387.

197 Ibid.
} 
full revelation of the Father, which is found in the Gospel of Jesus Christ. Ad Gentes teaches that people may respond in faith to that which God has revealed through the created order, even "before they are evangelized and can accept Christ explicitly." In this way, Ad Gentes is also consistent with nouvelle théologie's understanding of the overlapping relationship of the natural and the supernatural.

While not an exhaustive study of the Council documents, O'Collins's essay demonstrates that the concerns of nouvelle théologie are clearly reflected in several of its key statements. These teachings, along with the other statements of the Council, ultimately brought about a series of broad changes in Catholic life, for both laypeople and members of religious communities. Prior to legitimation by the Second Vatican Council, however, nouvelle théologie was already having an impact on the lives of the Sisters of Loretto. As they sought to provide improved education and theological formation for members of the congregation, Sisters encountered the writings of the nouveaux théologiens during the late 1950s and early 1960s. As they engaged with these new ideas, nouvelle théologie began to reshape their understanding of their role as women religious in the Church and the world. The Sisters' embrace of nouvelle théologie will be the subject of the next section. 


\section{THE SISTERS OF LORETTO EMBRACE NOUVELLE THÉOLOGIE}

In 1957, Loretto leadership selected Sisters Ann Richard White and Mary Frances Lottes to begin graduate studies in theology. ${ }^{198}$ Together, they traveled to Rome to begin coursework at the Pontifical Institute Regina Mundi, a newly established school focused exclusively on advanced theological training for women religious. White and Lottes relished their time in Rome, the heart of Catholic spiritual and intellectual life, enjoying their studies at Regina Mundi and finding other opportunities to learn from eminent scholars living and working in the city. In January of 1959 , for example, White wrote excitedly to Mary Luke Tobin that, "Father [Jean] Daniélou is giving a talk during February at the French Church in Rome." Though puzzled by his intended subject matter, "something about the progress of science in the fourth century," she wrote admiringly, “...with a mind like his, I guess one should be surprised at nothing."

Daniélou was, of course, one of the figures associated with nouvelle théologie: the progressive movement among some European Catholic scholars who challenged the prevailing neo-Scholastic theology and hoped to bring about a renewal in Catholic spirituality by reconnecting faith with lived experience. White's letter offers no such explanation, however. She assumes that Tobin, and anyone else permitted to read her

\footnotetext{
198 In June 1967, all Sisters of Loretto were given the option to revert to using their birth names, rather than the traditional religious names they had adopted upon entering the convent. Sr. Ann Richard White was known simply as Sr. Ann White from this time until her death in 2014. Sr. Mary Frances Lottes has retained this name throughout her life.

${ }^{199}$ Ann Richard White to Mary Luke Tobin, January 12, 1959. Loretto Archives, Loretto Motherhouse, Nerinx, KY.
} 
letter, will know who Daniélou is and also understand why she would make time to hear him speak, even on an apparently odd topic. White's familiar tone, and the implied familiarity of the reader with regard to Daniélou's work, suggests that it was already well known among the Sisters of Loretto.

White was one of several Sisters of Loretto sent to study in Europe during the late 1950 s and early 60 s, as the order worked to improve and advance members' educational opportunities. Like White, all of these "Sister-students" stayed in regular correspondence with Mary Luke Tobin, then the congregation's Superior General, during their time abroad. The Sisters-students' correspondence with Tobin from this period, along with later recollections, reveal a congregation already broadly engaging with the main ideas of nouvelle théologie, both at home in the United States and studying abroad. Their correspondence further demonstrates that the Sisters of Loretto in the pre-Conciliar years were well aware of the progressive, avant-garde nature of nouvelle théologie, yet already regarded the movement's scholars as authoritative. As these new ideas took root, they resulted in changing attitudes among the Sisters about their role in the Church and the world, even as the order continued to observe traditional customs of religious life.

Sisters of Loretto on both sides of the Atlantic were engaging with nouvelle théologie in the pre-Conciliar years, through studies as well as personal contacts. Tobin's letters to the Sisters studying in Europe confirm that she was individually engaging with nouvelle théologie in the years prior to the Second Vatican Council, and making efforts to ensure that Sisters at home were also exposed to these ideas. She occasionally requested, for example, that one of the Sister-students send her recently published books by various nouveaux théologiens, as these were often not yet available in the United States, but 
could be obtained with relative ease in Europe. In October of 1961, for example, Tobin's letter to Sister Kristin McNamara, then studying at Regina Mundi in Rome, included a reminder to send her a copy of Canon Robert Guelluy's À L'écoute de Dieu [Listening to God] along with several other books. ${ }^{200}$ Tobin also requested different installments ("fascicles") of the Jerusalem Bible, the first Vatican-approved vernacular translation of the Scriptures based on ancient Hebrew and Greek sources, rather than on the Latin Vulgate. $^{201}$

The Jerusalem Bible installments, along with many of the contemporary publications by nouveaux théologiens, were often still available only in French during the late 1950s and early 1960s. Tobin read and spoke French quite ably, however, allowing her to keep well abreast of the most recent developments in Catholic theology, as she had no need to wait for English translations. ${ }^{202}$ She could also, if desired, translate excerpts she wished to share with the larger congregation. Because of the hierarchical structure of the Loretto congregation prior to Vatican II, Tobin as Mother Superior exerted broad influence over the ongoing spiritual and theological formation of all the Sisters under her leadership. Her personal interest in the nouvelle théologie and high regard for the work of the movement's scholars was an important factor in bringing these ideas to the other members of the congregation.

Tobin's letters also describe her efforts to bring nouveaux théologiens into direct contact with those Sisters who remained in the United States. In December of 1960, for

\footnotetext{
${ }^{200}$ Mary Luke Tobin to Kristin McNamara, October 7, 1961. Loretto Archives, Loretto Motherhouse, Nerinx, KY.

${ }^{201}$ Mary Luke Tobin to Jane Marie Richardson and Kristin McNamara, March 11, 1961. Loretto Archives, Loretto Motherhouse, Nerinx, KY.

${ }^{202}$ Kristin McNamara, interviewed by Carol Bolton, March 9, 2016, Loretto Jubilee Oral History Project, Kentucky Historical Society, Frankfort, KY.
} 
example, she related to McNamara and Jane Marie Richardson, both studying in Rome at the time, that another Sister, Frances de Sales, would be going to the University of Notre Dame the following summer to take a course with Father Jean Daniélou. She wrote, "I wish I could get the latter to give a talk at Loretto some week end. Maybe he will visit [the Abbey of] Gethsemani since one of [Thomas] Merton's books is dedicated to him, I notice.” ${ }^{203}$ Tobin's efforts to bring Father Daniélou for a visit were apparently successful, as she related to McNamara in July 1961, "We had a great day Sunday. Father Danielou [sic] and Father Louis [Thomas Merton] arrived about 10:00 am, and stayed with us till afternoon. Father D. gave two excellent talks - one on Ecumenism and one on the Missionary Spirit. He is very simple and lovable...since we taped both talks you will have an opportunity to hear them later.",204

Though Father Daniélou was perhaps the most notable of the nouveaux théologiens to visit and address the Sisters of Loretto, the influence of nouvelle théologie is apparent with regard to other scholars and writers invited to speak and to teach at the Motherhouse. For example, Daniélou shared his strong interest in the spirituality of the Early Church Fathers with Trappist Father Thomas Merton, who lived only a few miles from the Loretto Motherhouse at the Abbey of Gethsemani. ${ }^{205}$ Merton was a internationally recognized best-selling author, perhaps best known for his spiritual

\footnotetext{
${ }^{203}$ Mary Luke Tobin to Jane Marie Richardson and Kristin McNamara, December 3, 1960. Loretto Archives, Loretto Motherhouse, Nerinx, KY.

${ }^{204}$ Mary Luke Tobin to Kristin McNamara, July 18, 1961. Loretto Archives, Loretto Motherhouse, Nerinx, KY.

${ }^{205}$ Ron Dart, "Thomas Merton and Nouvelle Théologie," Clarion Journal of Spirituality and Justice, July 4, 2011. Accessed October 20, 2016, http://www.clarionjournal.com/clarion_journal_of_spirit/2011/07/thomas-merton-and-nouvelle-theologieby-ron-dart.html.
} 
autobiography, The Seven Storey Mountain, as well as other writings in support of civil rights, the peace movement, and other social justice issues.

Merton's concern for translating religious conviction into social and political action aligned with nouvelle théologie's emphasis on reconnecting faith with lived experience. Merton became a somewhat regular visitor at the Loretto Motherhouse, coming over periodically to give talks to the young novices and older Sisters, on prayer and spiritual formation. He also became a close friend and advisor to Tobin, discussing theology, spirituality, politics, social justice, and many other subjects in a lively correspondence until his untimely death in $1968 .^{206}$

Sisters also remember Scripture courses given to novices by Passionist Father Carroll Stuhlmueller during the early 1960s. ${ }^{207}$ A highly regarded Scripture scholar who taught at the Passionist Seminary then located in Louisville, Stuhlmueller sought to make the Biblical literature more accessible and understandable, writing about the literary forms used and the cultural traditions in which the different books were written. In a departure from the Neo-scholastic past, he encouraged all Catholics to study the Scriptures directly, for themselves. ${ }^{208}$

\footnotetext{
${ }^{206}$ Mary Luke Tobin, "The Door of Prophetic Friendship: Thomas Merton," in Hope is an Open Door (Nashville: Abingdon, 1981), 68-90. Another helpful source with regard to the friendship between Merton and Tobin is Hidden in the Same Mystery: Thomas Merton and Loretto, edited by Bonnie Thurston and Mary Swain, SL (Louisville, KY: Fons Vitae, 2010), which includes transcripts of talks given by Merton at the Loretto Motherhouse, an interview given by Tobin ten years after Merton's death, as well as numerous photographs.

${ }^{207}$ Maureen O'Connell interviewed by Carol Bolton, November 13, 2015, Loretto Jubilee Oral History Project, Kentucky Historical Society, Frankfort, KY.

${ }^{208}$ Donald Senior, C.P., "Caroll Stuhlmueller, C.P.: The Life and Scholarship of an Immortal Teacher," U.S. Catholic Historian 31, no. 4 (Fall 2013), pp. 47-62. Accessed October 19, 2016, http://muse.jhu.edu/article/539970.
} 
Interestingly, Tobin's letters also indicate that she invited scholars with differing viewpoints to address the Sisters, in addition to those who favored nouvelle théologie. In December of 1960, she related to McNamara and Richardson that the French Catholic philosopher Jacques Maritain had been invited to visit the monks at the nearby Abbey of Gethsemani. She hoped that he might also consider visiting the Sisters of Loretto while in the neighborhood. Maritain was not a nouvelle théologien, but in fact was a neo-Thomist who was critical of the nouvelle théologie. ${ }^{209}$ Nonetheless, he was one of the foremost Catholic intellectuals in the world at mid-century, whose work had an important influence on the development of philosophy and theology. His writing covered a broad range of subjects, including metaphysics, nature, religion, politics, art and aesthetics, as well as human rights. ${ }^{210}$ Tobin was clearly familiar with Maritain's work, and it is likely that many other Sisters were as well. Her hope for a visit with him, in spite of potential theological differences, reflected her ongoing efforts to keep the Loretto congregation abreast of current thinking in Catholic life.

As Tobin worked to expose U.S. Sisters of Loretto to the best of recent Catholic scholarship, she also sent eight Sisters to study theology in Europe. Here these Sisterstudents engaged the main ideas of nouvelle théologie: ressourcement; the overlapping

${ }^{209}$ John Saward, "L'Église a ravi son coeur: Charles Journet and the Theologians of Ressourcement on the Personality of the Church," in Ressourcement: A Movement for Renewal in Twentieth Century Catholic Theology, ed. Gabriel Murray and Paul Flynn, ed. 128. (Oxford: Oxford University Press, 2013).

Michael J. Kerlin, "Anti-modernism and the elective affinity between politics and philosophy," in Catholicism Contending with Modernity: Roman Catholic Modernism and Anti-Modernism in Historical Context, Darrell Jodock, ed. (Cambridge: Cambridge University Press, 2000), 334.

${ }^{210}$ Nicholas Bradbury, "The Pastoral Theology of Pierre-André Liégé: a critical and comparative study in pastoral and practical theology." (PhD diss., University of Cardiff, 2007), 41. Accessed November 1, 2016, http://orca.cf.ac.uk/55675/1/U584194.pdf.

"Jacques Maritain," Stanford Encyclopedia of Philosophy, accessed October 30, 2016, 
relationship of the natural with the supernatural; and the importance of Church engagement with the issues of modern life. Kristin McNamara, one of the Sisters selected for theological study in Europe, reported on the intensive Scriptural study required for her classes at Lumen Vitae Catechetical Institute, reflective of nouvelle théologie's emphasis on ressourcement, returning to the original sources of Christian inspiration. She described multiple courses on Scripture, each focused on a different aspect. Abbé Poelman taught a course on the New Testament Epistles of Paul, while Canon Giblet led another concurrent course on the Prophets of the Old Testament. Of Giblet's course, McNamara wrote:

His course on the prophets was especially fine as he gave such a good background in understanding their times and their relation to the people. Really, it seems so much in the catechetical program is based on the use of the Bible that one needs to study Scripture very carefully in order to teach religion at all...The professors stress the need to study the Bible deeply, first, of course, to know God and in order to use it correctly -- so we won't hack it into lovely stories. ${ }^{211}$

McNamara's tone of surprise at the extent of required Biblical study is revealing, as it indicates how great a departure this method was from the religious instruction to which she had been accustomed. Much in the same way that Neo-scholastic seminarians of the period learned theology "secondhand" via manuals and handbooks, religious instruction in early twentieth century America was given to young children and adult converts alike in a rote, didactic manner. Scripture was rarely referenced directly. Instead, instruction was based on a catechism, a document containing lessons in the form of

\footnotetext{
${ }^{211}$ Kristin McNamara to Mary Luke Tobin, April 12, 1960. Loretto Archives, Loretto Motherhouse, Nerinx, KY.
} 
questions and answers about essential points of doctrine. ${ }^{212}$ After attending catechism class at school or through their parish, students proved their readiness for the Sacraments by providing satisfactory oral answers to a series of questions asked of them by a priest. $^{213}$

The faculty McNamara encountered at Lumen Vitae sought to move catechetical instruction away from this model. Instead, they favored a "kerygmatic" approach to religious instruction, that focused on connecting students to original sources of Christian inspiration by communicating the Gospel message of salvation through Christ. ${ }^{214}$ This kerygmatic model of catechesis was pioneered by Austrian Jesuit Josef Jungmann, a professor at the University of Innsbruck alongside noted nouvelle théologien Karl Rahner. Jungmann believed the kerygmatic approach could help to restore vitality to Catholic life by fostering a faith that was truly personal, and that held implications for the lived experience of Catholic individuals, beyond pat answers to doctrinal questions. ${ }^{215}$ McNamara's correspondence indicated that Jungmann was referenced often at Lumen Vitae, with two of his books being required texts, and that he was considered by other professors to be an authority in the field of catechetics, the theology of religious instruction. ${ }^{216}$ Additionally, McNamara wrote that she and her fellow students had the

\footnotetext{
${ }^{212}$ From 1885 until the Second Vatican Council, the Baltimore Catechism, approved in 1885 , was considered the standard for catechetical instruction in the United States. The three volumes of this document are available at http://www.sacred-texts.com/chr/balt/. ${ }^{213}$ Michael P. Horan, "Josef Jungmann," Talbot School of Theology at Biola University, accessed October 4, 2016, http://www.talbot.edu/ce20/educators/catholic/josef jungmann/.

${ }^{214}$ Kristin McNamara to Mary Luke Tobin, November 9, 1959. Loretto Archives, Loretto Motherhouse, Nerinx, KY.

${ }^{215}$ Horan, "Josef Jungmann."

${ }^{216}$ Kristin McNamara to Mary Luke Tobin, July 4, 1959. Loretto Archives, Loretto Motherhouse, Nerinx, KY.
} 
opportunity to meet Jungmann and attend one of his lectures as part of a schoolsponsored study excursion in the spring of $1960 .{ }^{217}$ Though Jungmann was not a scholar specifically associated with the nouvelle théologie, his kerygmatic model of catechesis reflected its influence, through the shared goal of renewal through return to the original sources of inspiration.

McNamara also encountered ressourcement in her moral theology course at Lumen Vitae, taught by Father Bernard Häring. Writing to Tobin about his class, McNamara described Häring's approach:

The theme is that Christian morality is based on the law of love, that law which is imprinted on each one's heart by the sacraments. God gives Himself completely and in response we are to offer our whole being in love. Laws, exterior ones, are only the bare minimum whereas in Christ we are to give all. ${ }^{218}$

This approach represented a distinct departure from Neo-scholastically influenced moral theology, which focused almost entirely on the legalistic identification of sinful behavior, in order to prepare young priests to serve as confessors for their parishioners. ${ }^{219} \mathrm{In}$ contrast, Häring focused on the message of Christ's love found in the Gospels, proposing "a biblical, liturgical, Christological and life-centered moral theology...based on the covenant -- the good news of God's loving gift for us and our grateful response...He staunchly opposed any legalism that made God into a controller rather than a gracious

Kristin McNamara to Mary Luke Tobin, November 9, 1959. Loretto Archives, Loretto Motherhouse, Nerinx, KY.

${ }^{217}$ Kristin McNamara to Mary Luke Tobin, June 4, 1960. Loretto Archives, Loretto Motherhouse, Nerinx, KY.

${ }^{218}$ Kristin McNamara to Mary Luke Tobin, March 12, 1960. Loretto Archives, Loretto Motherhouse, Nerinx, KY.

${ }^{219}$ Charles Curran, "Take and Read: The Law of Christ," National Catholic Reporter, February 1, 2016. Accessed October 11, 2016, https://www.ncronline.org/blogs/takeand-read-law-christ. 
savior."220 McNamara maintained contact with Häring even after leaving Lumen Vitae, which suggests that his teaching bore strong influence with her. In November of 1960, for example, McNamara was studying at Regina Mundi when she wrote to Häring, who was also in Rome at the time, and made plans for Richardson and herself to meet with him on an upcoming Sunday. ${ }^{221}$

In addition to ressourcement, McNamara and other Sister-students encountered nouvelle théologie's emphasis on the overlapping relationship between the natural and the supernatural. This focus was reflected in their courses on psychology, particularly religious psychology and social psychology. In these fields of study, scholars were using empirical, data-driven insights into human behavior and learning processes to improve instruction in matters of faith. This approach represented a departure from the NeoScholastic influence of early twentieth century catechetics, in which revelation and faith were understood to be completely extrinsic gifts of grace. In this approach, an individual's life experience mattered very little with regard to their ability to comprehend and embrace religious teaching. Understanding was simply gifted by God, as evidenced by correct answers to doctrinal questions, or it was not.

The inclusion of psychology, by contrast, foregrounded the lived experience of the "catechumen," a student of religious instruction, acknowledging that prior experiences, developmental stage, or emotional state could play a role in one's ability to understand or willingness to accept religious teaching. One of McNamara's professors,

\footnotetext{
${ }^{220}$ Charles Curran, "Bernard Häring: a moral theologian whose soul matched his scholarship," National Catholic Reporter, July 17, 1998. Accessed October, 11, 2016, http://natcath.org/NCR_Online/archives2/1998c/071798/071898h.htm.

${ }^{221}$ Jane Marie Richardson to Mary Luke Tobin, November 29, 1960. Loretto Archives, Loretto Motherhouse, Nerinx, KY.
} 
Canon Laloup of Université Catholique de Louvain, "said in our presentation we must see our hearer, understand his way of thinking and adapt to that. Today man wants the tangible, the facts, action...give the personal temoinage [sic]...there must be the person to person relationship."222 McNamara's reference here to temoignage, one's own testimony or account, also evidenced a regard for the lived experience of the catechist, the religious teacher, in communicating matters of doctrine to students. McNamara seemed to indicate that catechists, rather than teaching students to simply parrot the catechism, should share their own faith experience, becoming a "tangible...act[ing]" representation of the doctrine they sought to communicate. ${ }^{223}$

McNamara and Richardson encountered a similar viewpoint in their independent discussions with Father Alfonso Nebreda, another acquaintance of McNamara's from Lumen Vitae. At the time McNamara and Richardson were studying at Regina Mundi, Nebreda was finishing his doctorate and preparing to teach at the Pontifical Gregorian University in Rome, and the Sisters met with him regularly. ${ }^{224}$ Richardson and McNamara both discussed Nebreda in their correspondence, passing along to Mary Luke Tobin the interesting things he said to them. In April of 1961, Richardson recounted a recent "inspiring" visit with Nebreda:

He went on to say that since God is responsible for making you you [sic], $\mathrm{He}$ is the First to respect this invisible uniqueness, hence he can never force His Love upon anyone. False violence, reckless zeal, thrusted

\footnotetext{
${ }^{222}$ Ibid. Note on "temoinage:" This is likely a misspelling of temoignage, which can be translated as "testimony," or "account." See http://www.collinsdictionary.com/dictionary/french-english/t\% $\%$ 3\%A9moignage. ${ }^{223}$ Ibid.

${ }^{224}$ Kristin McNamara to Mary Luke Tobin, November 19, 1960. Loretto Archives, Loretto Motherhouse, Nerinx, KY.

Jane Marie Richardson to Mary Luke Tobin, November 28, 1961. Loretto Archives, Loretto Motherhouse, Nerinx, KY.
} 
gifts...these are the antithesis of true love, which must be accompanied by understanding or else it is the greatest of abuses. ${ }^{225}$

In a subsequent letter, Richardson wrote in February of 1962, "now that Fr. [Nebreda] has finished his thesis we go over weekly for confession and a visit. What beautiful understanding and reverence for souls! Always so full of Christian confidence - God is glorified even through our faults. He loves us the way we are."226

Nebreda's emphasis on God's acceptance of imperfect individuals, and His respect for their "invisible uniqueness," suggests the influence of nouvelle théologie's understanding of an overlapping relationship between natural and supernatural, in which human beings possess an innate inclination toward the Divine. His assertion than God does not force love on anyone represents a departure from the Neo-scholastic understanding of faith as extrinsic and imposed by God.

Nebreda, like Josef Jungmann, was an important figure in the kergymatic approach to catechesis, and his ideas about "pre-evangelization" were influential among Catholic missionaries. Also reflecting nouvelle théologie's emphasis on the relationship between natural and supernatural, he believed that a person's background and/or cultural milieu impacted their willingness or ability to receive religious teaching. He taught that a catechist or missionary must first work to establish a personal relationship of trust with

\footnotetext{
225 Jane Marie Richardson to Mary Luke Tobin, April 29, 1961. Loretto Archives, Loretto Motherhouse, Nerinx, KY.

${ }^{226}$ Jane Marie Richardson to Mary Luke Tobin, February 17, 1962. Loretto Archives. Loretto Motherhouse, Nerinx, KY.
} 
those whom they sought to catechize or evangelize, including identifying with their cultural milieu. ${ }^{227}$

For the nouveaux théologiens, this need to relate to everyday parishioners or catechumens meant that it was essential for the Church to actively engage with the cultural and social issues of the modern world. Richardson encountered this aspect of nouvelle théologie in her studies at Institut Catholique in Paris, where she went for further study following her experience at Regina Mundi. Here she was especially pleased at being able to study with Father Pierre-André Liégé, a Dominican priest who had studied under noted nouveaux théologiens Yves Congar and Marie-Dominique Chenu. ${ }^{228}$ Liégé also favored the kerygmatic approach to religious education, and used his experience to help pioneer the study of pastoral theology in France. Liégé's work focused on the practical application of theological concepts in everyday life, with the goal of helping Catholic parishioners reconnect their faith with their lived experience. ${ }^{229}$ Richardson wrote to Tobin that "Father [Liégé] has just finished showing us the relation between speculative (scholastic) theology and pastoral. Excellent -- well thought out."230

\footnotetext{
${ }^{227}$ Matt Halbach, "New Pope, New Evangelization, New Return to Old (but Good) Ideas," Catechetical Leader 24, no. 5 (September 2013): 19. Accessed October 25, 2016, http://www.21stcenturycatholicevangelization.org/uploads/5/1/6/4/5164069/new_pope_n ew evangelization.pdf.

${ }^{228}$ Jane Marie Richardson to Mary Luke Tobin, November 9, 1962. Loretto Archives, Loretto Motherhouse, Nerinx, KY.

${ }^{229}$ Nicholas Bradbury, "The Pastoral Theology of Pierre-André Liégé: a critical and comparative study in pastoral and practical theology." (PhD diss., University of Cardiff, 2007). Accessed November 1, 2016, http://orca.cf.ac.uk/55675/1/U584194.pdf.

${ }^{230}$ Jane Marie Richardson to Mary Luke Tobin, November 9, 1962. Loretto Archives, Loretto Motherhouse, Nerinx, KY.

Richardson's familiarity with Liégé may possibly have been due to McNamara's prior exposure to his work. McNamara quoted Liégé's Adults in Christ at length in a letter to Tobin, dated February 19, 1960, written during her time at Lumen Vitae. She also mentioned that Liégé was held in high regard by her professors there. Tobin, writing to
} 
Richardson also praised her other professors at Institut Catholique, particularly Father Danet, who taught moral theology. She was pleased to find that he often referenced the work of Bernard Häring, with whom she and McNamara had been in contact while in Rome. Describing Danet's course to Tobin, she wrote,

"he says some very beautiful and profound things, often just in passing. For example, at the end of class last week: 'So often on application blanks (for entering Nov.[itiate]): 'Can she obey?' And almost never: 'Is she capable of loving?' Re religious poverty: 'Choice of religious is a renouncement of things in order to place oneself more completely in relation with persons.",231

Richardson and McNamara also encountered the importance of Church engagement with modernity in discussions with Father Tom Stransky during their time in Rome. An American priest, Stransky was then serving as a staff member for the Vatican Secretariat for the Promotion of Christian Unity, in preparation for the Second Vatican Council. ${ }^{232}$ In this role, he worked to ensure that the Church considered the perspectives of those outside the ecclesiastical hierarchy, by inviting representatives of non-Catholic faiths, as well as members of male and female Catholic religious orders, to be present as observers at the Council.

Richardson wrote in October of 1961, "Fr. Stransky agreed to have monthly seminars with us this year...Our first is scheduled for the week of Nov. 13 and already our number is too large!"233 Stransky's concern for the cultural relevance of the Church is

McNamara and Richardson on April 26, 1961, related that Liégé's Adults in Christ was being used in the formation program for new postulants.

${ }^{231}$ Ibid.

232 "Father Thomas Stransky," Paulist Fathers, accessed October 24, 2016, https://www.paulist.org/who-we-are/leadership/fr-thomas-stransky/.

${ }^{233}$ Jane Marie Richardson to Mary Luke Tobin, October 28, 1961. Loretto Archives, Loretto Motherhouse, Nerinx, KY. 
apparent in the tentative subject matter chosen for these meetings. The group planned to discuss "Christian Humanism in light of [Teilhard de] Chardin," "Christian Unity," and “the Mind of Modern Man," among other topics. ${ }^{234}$ These all suggest a concern for awareness of and connection with questions of contemporary life and thought. Teilhard de Chardin, for example, as both a priest and a scientist, sought to articulate a synthesis of Christian faith with modern evolutionary theory. After years of suppression by Church authorities, his work had only recently beem published, and was being widely read as it was translated into multiple languages. Richardson, when she continued her studies in Paris, discovered that "Chardin is the figure in the book stores - most current writing features him...Since so many at school refer to him, I'm glad to have [Chardin's] D[ivine] M[ilieu]...on my desk."235

“Christian Unity," too, was an idea Catholics had embraced only somewhat recently. Since the sixteenth century Council of Trent, Catholics had been encouraged to consider all non-Catholics, even those who also professed Christian faith, as apostates or heretics in need of evangelization and conversion. Stransky's religious order, the Missionary Society of Saint Paul the Apostle (the "Paulist Fathers"), had actually been founded with the express purpose of converting America to Roman Catholicism. ${ }^{236}$ During the early to mid-twentieth century, however, the Church had gradually begun to adopt a more ecumenical stance. Though Catholics still claimed to embody the fullest

\footnotetext{
234 Ibid.

235 Jane Marie Richardson to Mary Luke Tobin, November 9, 1962. Loretto Archives, Loretto Motherhouse, Nerinx, KY. 236 “In Memoriam: Paulist Fr. Tom Stransky, C.S.P. (1930-2019)," Paulist Fathers. Accessed April 19, 2020, https://paulist.org/the-conversation/in-memoriam-paulist-frthomas-stransky-1930-2019/.

See also: "Our History.” Paulist Fathers. https://paulist.org/who-we-are/our-history/.
} 
revelation of Divine truth, their leaders had begun to recognize the necessity of cooperation with other Christian denominations, particularly in response to the crises of the First and Second World Wars, as well as ongoing missions efforts.

Stransky, as mentioned, was directly involved with Vatican efforts to promote Christian unity, especially as it related to the upcoming Council. He went on to play an important role in drafting the official Council documents related to this topic, including Nostra Aetate (the Decree on Non-Christian Religions), Unitatis Redintegratio (the Decree on Ecumenism), and Dignitatis Humanae (the Decree on Religious Freedom). His ecumenical efforts continued in the years following the Council, through participation in cross-denominational organizations such as the World Council of Churches. Eventually elected President of the Paulist Fathers, Stransky helped to reorient the order's apostolate, leading them to "approach other Christians with mutual respect and engage in earnest theological exchange as the way to most effectively achieve Christian unity."237

As the Sister-students engaged with the themes of nouvelle théologie through their studies and personal contacts, they were fully aware of the dichotomy between these new approaches to theology, and the more conservative Neo-scholastic methods they were challenging. Rather than regarding this progressivism as a reason for caution, the Sisters seem to have embraced it, actively rejecting Neo-scholastic teaching. This attitude is most evident in McNamara's and Richardson's experiences at Regina Mundi, where they found that many scholars still approached their subject matter from the more traditional, manualist viewpoint.

\footnotetext{
${ }^{237}$ Dennis Sadowsky, "Father Thomas Stransky had key role in ecumenical, interreligious work," Crux, September 9, 2019. Accessed February 18, 2020, https://cruxnow.com/obituary/2019/09/father-thomas-stransky-had-key-role-inecumenical-interreligious-work/.
} 
McNamara's correspondence offers an interesting point of comparison between the nouvelle théologie she had encountered at Lumen Vitae and the Neo-scholasticism still predominant at Regina Mundi. Though she still enjoyed her courses, McNamara found the theological conservatism of Regina Mundi stifling by comparison to Lumen Vitae's more open, discussion-oriented atmosphere. She later remembered feeling as though she had "just gone from the twenty first [sic] century to the eighteenth century. ${ }^{, 238}$ In an October, 1960, letter to Tobin, soon after her arrival at Regina Mundi, McNamara stated the opinion that, "St. Thomas was canonized but not the Summa - it is an excellent and praiseworthy reference but not a textbook." ${ }^{, 239}$ A few months later she complained about the didactic teaching methods employed at Regina Mundi:

It seems to me in dogma class all we do is get a point, grace for example, and before knowing what grace is we have all the errors that have appeared in its regard. Next comes the distinctions, causes, and effects. This whole time I still don't know what grace is, what it has to do [with] God, life, and man. ${ }^{240}$

McNamara's comments here indicate the influence of the nouvelle théologie on her thinking, as she highlighted Neo-scholastic theology's disconnection from original sources of inspiration, in favor of sole reliance upon the Summa, as well as a lack of any application to lived experience. Though there is no indication she was disrespectful toward her professors, McNamara's willingness to openly question the teaching of

\footnotetext{
${ }^{238}$ Kristin McNamara, interviewed by Carol Bolton, March 9, 2016, Loretto Jubilee Oral History Project, Kentucky Historical Society, Frankfort, KY.

${ }^{239}$ Kristin McNamara to Mary Luke Tobin, October 30, 1960. Loretto Archives, Loretto Motherhouse, Nerinx, KY.

Mary Frances Lottes' letters also confirm, "Most of the outside study for Dogma is from the Summa and Garrigou-Lagrange commenting on the Summa. (Mary Frances Lottes to Mary Luke Tobin, May 6, 1960.)

${ }^{240}$ Kristin McNamara to Mary Luke Tobin, February 11, 1961. Loretto Archives, Loretto Motherhouse, Nerinx, KY.
} 
authority figures is significant. She did not seem to be concerned about adverse consequences, and wrote with confidence that Tobin would be in agreement, or at least understand her position.

McNamara's confidence in Tobin was not misplaced, as the Superior also supported Richardson when she expressed disappointment with the moral theology course at Regina Mundi. ${ }^{241}$ Entering her second year of study there, Richardson went so far, at Tobin's suggestion, as to request to study moral theology with a different professor. This was an unusual appeal, as Regina Mundi's international student body was divided into language-specific "sections." Richardson applied to the dean, asking special permission to join the Institute's cohort of French-speaking students for their course, rather than endure another year with Father Abbott Williams, who taught moral theology in English. ${ }^{242}$ Though the bid was ultimately unsuccessful, Tobin's encouragement of Richardson's appeal, in spite of the difficulty it might present, provides an interesting read of the Congregation's direction during this period. It represented a subtle assertion of independence from the official teaching authority of the Church, as represented by Regina Mundi and its faculty, confirming that the Sisters of Loretto were leaving the traditional Neo-scholastic theology behind.

\footnotetext{
${ }^{241}$ Jane Marie Richardson to Mary Luke Tobin, November 19, 1960. Loretto Archives, Loretto Motherhouse, Nerinx, KY.

${ }^{242}$ Mary Luke Tobin to Jane Marie Richardson, September 5, 1961. Loretto Archives, Loretto Motherhouse, Nerinx, KY. Jane Marie Richardson to Mary Luke Tobin, October 28, 1961. Loretto Archives, Loretto Motherhouse, Nerinx, KY.

Interestingly, Ann Richard White and Mary Frances Lottes seem to have had no difficulty with Fr. Williams. Lottes comments on his use of "the more modern moralists" in addition to the Summa (5-6-60), and White relates his visit to her hospital room, referring to him as "such a charming person that he puts everyone at ease." (3-17-59)
} 
Additionally, the Sister-students sought to share more progressive theological ideas with other women religious they encountered at Regina Mundi. Richardson wrote to Tobin that "one of the American Sisters at school invited Sister [Kristin] and me to join their privately-established seminar group... ! There are ten others, Fr. Francis Murphy CSSR [sic] is to be the new director...We are hoping he is a protégé of Häring!"243 Though she later described one of Murphy's seminars as "stimulating," Richardson found that "the Sisters in this particular group are more conservative than those in our other circle." 244 Undaunted, however, she regarded the situation as "a good opportunity to introduce new thinking but gently. So we are glad to be members." 245 Richardson's words demonstrate that she clearly understood the dichotomy between more traditionally conservative Catholic theology and the new ideas embraced by the nouvelle théologie. She saw herself as having embraced a better way of thinking and wished to share this with other Sisters. In communicating this to Tobin, she implied a belief that her Superior shared this view, and would support her attempts to discuss these new theological ideas with others.

Fully aware of nouvelle théologie's progressive nature, the Sister-students still turned to the writings of the nouveaux théologiens for both academic study and personal spiritual guidance. McNamara made references to the work of notable nouveaux

\footnotetext{
${ }^{243}$ Jane Marie Richardson to Mary Luke Tobin, November 28, 1961. Loretto Archives, Loretto Motherhouse, Nerinx, KY.

Note on "CSSR:" This is likely a misrendering of the religious suffix C.Ss.R., which stands for Congregatio Sanctissimi Redemptoris, the Latin name for the Congregation of the Most Holy Redeemer. Priests of this order are commonly referred to as "Redemptorists." See http://www.cssr.news/. Father Bernard Häring was also a Redemptorist, hence the Sisters' hope that Murphy's theological views would be similar. ${ }^{244}$ Jane Marie Richardson to Mary Luke Tobin, February 17, 1960. Loretto Archives, Loretto Motherhouse, Nerinx, KY.

${ }^{245}$ Ibid.
} 
théologiens from her early letters to Tobin, and spoke of these scholars favorably. In November 1959, for example, McNamara described a class at Lumen Vitae in which she was having difficulty with some of the concepts presented. She informed Tobin that she had been reading nouveaux théologiens Henri de Lubac and Jean Daniélou for clarification, indicating she was already familiar with their work, and trusted it as reliable teaching. ${ }^{246}$ Richardson also turned to the nouveaux théologiens for guidance during her studies. Only recently arrived in Rome, Richardson wrote to Tobin in November of 1960 that she had been using Jean Daniélou's Advent for her personal meditation. ${ }^{247}$ Though not required for her classes, Richardson also made time to read Teilhard de Chardin's The Divine Milieu, and Hans Urs von Balthasar's Prayer while studying at Regina Mundi. ${ }^{248}$ The sister-students' reliance upon of the work of nouveaux théologiens, both academically and personally, and their eagerness to relate these encounters to Mary Luke Tobin, indicate the high regard in which the order held these writers, before their work at the Second Vatican Council lent ecclesiastical legitimacy to their ideas.

Richardson, as well as McNamara, demonstrated awareness of the dichotomy between the new approaches to theology then developing in Europe, and the more conservative Neo-scholastic methods they were challenging. Their correspondence also makes clear that they, along with the leadership of their community, were already

\footnotetext{
${ }^{246}$ Kristin McNamara to Mary Luke Tobin, November 19, 1959. Loretto Archives, Loretto Motherhouse, Nerinx, KY.

${ }^{247}$ Jane Marie Richardson to Mary Luke Tobin, November 29, 1960. Loretto Archives, Loretto Motherhouse, Nerinx, KY.

248 Jane Marie Richardson to Mary Luke Tobin, July 23, 1961. Loretto Archives, Loretto Motherhouse, Nerinx, KY.

Jane Marie Richardson to Mary Luke Tobin, October 22, 1961. Loretto Archives, Loretto Motherhouse, Nerinx, KY.
} 
embracing these theological insights in the years before the opening of Vatican II, when nouvelle théologie became an influential factor in reforms decreed by the council fathers.

As the Sisters of Loretto engaged with this new teaching, it began to reshape their views of themselves and their community life, as well as their understanding of the role women religious should play in the Church and the wider world. The Sister-students' correspondence during this period reveals an excitement and sense of empowerment at the new knowledge they were gaining and the possibilities it opened for them, alongside a subtle tension between the continued observance of longstanding religious customs and an emerging sense of freedom and personal responsibility. Describing her experience at Lumen Vitae in March of 1960, McNamara wrote, "It just seems one gets awakened to the greatness and wonder of the whole vista of Christian life here." ${ }^{249}$ A few weeks later, she shared her eagerness to begin applying her newfound knowledge: "Lumen Vitae inspires one to want to get out and work, be with those in need...there are many, many times when I cannot wait to apply all this, to get into the classroom again...,250 Remembering the impact of her experiences later, McNamara commented,

I just felt much so freer. I just felt, 'I've got things to figure out. I don't have to accept what is said by Father. Or Sister, or Mother.' ... But seeing possibilities...more than 'have to,' or 'must,' or 'should,' or 'I'll get punished.' Punishment went out the window. ${ }^{251}$

McNamara's words reveal that her outlook on her religious life, and her understanding of her role in it, were beginning to change due to her engagement with

\footnotetext{
${ }^{249}$ Kristin McNamara to Mary Luke Tobin, March 27,1960. Loretto Archives. Loretto Motherhouse, Nerinx, KY.

${ }^{250}$ Kristin McNamara to Mary Luke Tobin, April 12, 1960. Loretto Archives, Loretto Motherhouse, Nerinx, KY.

${ }^{251}$ Kristin McNamara, interviewed by Carol Bolton, March 9, 2016, Loretto Jubilee Oral History Project, Kentucky Historical Society, Frankfort, KY.
} 
nouvelle théologie. Moving from a duty-based religious practice toward a more relational spirituality, she also felt free and competent to question the teachings of religious authorities, drawing her own conclusions about Scripture and theology. She was excited to share this new approach, though it is interesting to note that she still conceived of doing so within the traditional context of a Catholic school classroom setting.

This tension, between emerging ideas and the traditional customs of religious life, is a hallmark of the Sister-students' efforts to navigate new and changing dynamics in their religious life. By comparison to the highly structured and scheduled convent life they had been accustomed to, the Sister-students in Europe seem to have had wide latitude with regard to use of their time, as well as their movements. Outside of scheduled classes, mealtimes, and the occasional school-sponsored activity, the Sisters themselves seem to have determined how they would spend their time. Though much of it was necessarily devoted to reading and study, they wrote regularly to Mary Luke Tobin about their outings and explorations in Brussels, Rome, Paris, Oxford, and London as well as day trips and weekend excursions to other cities, such as Assisi, Florence, Naples, and Munich. ${ }^{252}$ The Sisters also seem to have socialized rather freely, accepting invitations from fellow students or local convent Sisters for meals and holiday festivities.

\footnotetext{
${ }^{252}$ Jane Marie Richardson to Mary Luke Tobin, October 30, 1960. Loretto Archives, Loretto Motherhouse, Nerinx, KY.

Jane Marie Richardson to Mary Luke Tobin, April 8, 1961. Loretto Archives, Loretto Motherhouse, Nerinx, KY.

Jane Marie Richardson to Mary Luke Tobin, July 9, 1961. Loretto Archives, Loretto Motherhouse, Nerinx, KY.

Jane Marie Richardson to Mary Luke Tobin, August 15, 1961. Loretto Archives, Loretto Motherhouse, Nerinx, KY. Jane Marie Richardson to Mary Luke Tobin, January 1, 1962. Loretto Archives, Loretto Motherhouse, Nerinx, KY. Jane Marie Richardson to Mary Luke Tobin, October 18, 1962. Loretto Archives, Loretto Motherhouse, Nerinx, KY.
} 
McNamara, for example, spent her Thanksgiving holiday at Lumen Vitae attending a dinner party given by two American fellow students, Father Asselin and Brother Raymond, something that would have been unacceptable at home. ${ }^{253}$ Richardson, attending a summer Biblical conference in England, wrote of an enjoyable weekend spent at the convent of some English Sisters she had befriended. ${ }^{254}$ This, too, would have been an unlikely occurrence in the structured convent life the Sisters lived in the United States. Though most of the Sister-students' social interactions were with other religious individuals, their apparent discretion in accepting or declining invitations is notable.

In addition to choosing how they spent much of their time, Sister-students also saw to their own personal and medical needs while in Europe. Provided with money for expenses, they were responsible to budget this appropriately, purchasing necessary supplies, items of clothing, books, and travel tickets, all tasks that would normally have been handled by a superior. In one early example of such responsibility, Sister Ann Richard White decided, without prior input from Tobin, to undergo a recommended surgery, to mitigate some health problems she experienced while studying in Rome. ${ }^{255}$ Tobin regularly gave Richardson and McNamara the responsibility of shopping for books

${ }^{253}$ Kristin McNamara to Mary Luke Tobin, November 26, 1959. Loretto Archives, Loretto Motherhouse, Nerinx, KY.

${ }^{254}$ Jane Marie Richardson to Mary Luke Tobin, August 3, 1961. Loretto Archives, Loretto Motherhouse, Nerinx, KY.

Mary Luke Tobin to Mary Frances Lottes and Ann Richard White, January 29, 1959. Loretto Archives, Loretto Motherhouse, Nerinx, KY.

${ }^{255}$ Mary Frances Lottes and Ann Richard White to Mary Luke Tobin, December 11, 1958. Loretto Archives, Loretto Motherhouse, Nerinx, KY.

Ann Richard White to Mary Luke Tobin, December 14, 1958. Loretto Archives, Loretto Motherhouse, Nerinx, KY.

White seems to have undergone a second procedure the following summer, also deciding this independently. (Mary Luke Tobin to Ann Richard White, June 29, 1959. Loretto Archives, Loretto Motherhouse, Nerinx, KY.) 
and other small items, such as crucifixes, on behalf of the congregation. Tobin further entrusted these Sisters with investigating a possible major purchase: she instructed them to contact the Volkswagen company regarding the cost of a vehicle, as well as shipment from Germany to South America, where she intended it to serve the congregation's newly established mission in Bolivia. ${ }^{256}$

Alongside this high degree of personal discretion and responsibility, the Sisterstudents continuted to request special permission from Tobin for comparatively trivial things, in keeping with their pre-Conciliar rules and customs. During their time in Europe, Sister-students wrote asking Tobin's permission to walk to the library alone, to eat between meals, to stay up after 10 p.m., to have a typewriter repaired, and to pray in one's own room instead of walking to church every morning. ${ }^{257}$ At times, these appeals to Tobin came directly following an instance in which a Sister had acted independently.

White's surgery presents an example: after making this decision on her own and undergoing the procedure, she seemed mortified by an apparent breach of formality, when her parents learned of the operation before Tobin. "You can imagine my embarrassment," she wrote, "to have you find out about the operation from my parents. It never entered my feeble brain that the letters would not arrive simultaneously. I know

\footnotetext{
${ }^{256}$ Mary Luke Tobin to Kristin McNamara and Jane Marie Richardson, December 3, 1960. Loretto Archives, Loretto Motherhouse, Nerinx, KY.

${ }^{257}$ Ann Richard White to Mary Luke Tobin, July 30, 1959. Loretto Archives, Loretto Motherhouse, Nerinx, KY.

Kristin McNamara to Mary Luke Tobin, June 29, 1960. Loretto Archives, Loretto Motherhouse, Nerinx, KY. Mary Luke Tobin to Mary Frances Lottes and Ann Richard White, October 28, 1958. Loretto Archives, Loretto Motherhouse, Nerinx, KY.
} 
you understand, but please accept my apologies. ${ }^{.258}$ In the same correspondence, White thanked Tobin for a recent "permission granting letter," saying "I am so grateful to have you put down very definitely what I may and may not do. One has to be careful of getting too independent in a situation such as ours. ${ }^{259}$

McNamara, at Lumen Vitae in the fall of 1959, also struggled with knowing what was acceptable. Feeling conflicted about whether or not she was right to have accepted Father Asselin's Thanksgiving invitation, she wrote to Tobin afterward: "Now before any other similar occasions arise, could I ask you some principle to follow. I know we don't go out for enjoyment but sometimes we don't know what to do or answer on the spur of the moment. ${ }^{260}$

Though acting more independently, the Sister-students still seemed to exhibit relief at being able to hand off more significant decisions to Tobin. Following her year of study at Lumen Vitae, McNamara was approached by Father George Hagmaier about possibly writing a chapter for an upcoming book on adult catechetics. She wrote immediately to Tobin for advice, confessing, “...I am glad I can turn to you for an answer - or is that shifting the responsibility for making a decision, I don't think so. I would like for the question to be under obedience. At the present moment I don't know what the answer would be if I were to make my own decision. ${ }^{261}$ In another example, Jane Marie Richardson had some discussion with Tobin, in the fall of 1961, about whether she

\footnotetext{
${ }^{258}$ Ann Richard White to Mary Luke Tobin, December 14, 1958. Loretto Archives, Loretto Motherhouse, Nerinx, KY.

${ }^{259}$ Ibid.

${ }^{260}$ Kristin McNamara to Mary Luke Tobin, November 26, 1959. Loretto Archives, Loretto Motherhouse, Nerinx, KY.

${ }^{261}$ Kristin McNamara to Mary Luke Tobin, October 17, 1961. Loretto Archives, Loretto Motherhouse, Nerinx, KY.
} 
should continue her studies for a second year at Regina Mundi, or perhaps transfer to Institut Catholique instead. Asked for her thoughts on the matter, Richardson shared some remarks, but ultimately concluded, "I am glad the decision is yours."262

The Sister-students' ongoing concern for formality, hierarchy, and deference to authority, in tension with their emerging sense of personal responsibility and freedom, reveals a congregation already in some degree of flux, both before and during the Second Vatican Council. The nouvelle théologie with which they had been engaged was beginning to reshape their understanding of God, themselves, and their role as women religious, yet the old hierarchical structures of authority and obedience, and the exclusive commitment to the traditional teaching apostolate remained in place. However, the Sisterstudents' correspondence does give evidence that they were just beginning to consider different possibilities. Jane Marie Richardson spent several weeks teaching catechism to children at the American army base in Stuttgart during the summer of 1961, and considered returning the following year. In January 1962, however, she confessed to Mary Luke Tobin:

"To be perfectly honest with you, the prospect of teaching catechism does not thrill me. To say such a thing here, in present circumstances, would be unthinkable. But it is true: I do not really know how to teach young children...It is the adult contacts that I particularly relished and found so stimulating and enriching."263

McNamara, preparing for mission work in South America, also seemed drawn toward ministry to adults. She wrote to Tobin about her excitement at the possibility the Sisters of Loretto, in lieu of starting another school, might open a hostel for university students

\footnotetext{
262 Jane Marie Richardson to Mary Luke Tobin, September 11, 1961. Loretto Archives, Loretto Motherhouse, Nerinx, KY.

${ }^{263}$ Jane Marie Richardson to Mary Luke Tobin, January 30, 1962. Loretto Archives, Loretto Motherhouse, Nerinx, KY.
} 
in Santiago. ${ }^{264}$ Anna Barbara Brady, writing from Lumen Vitae in 1963, seemed rather certain that a change in the Congregation's apostolate was forthcoming. She wrote, “After reading Cardinal Suenens' book [The Nun in the World: New Dimensions in the Modern Apostolate], I couldn't help but envisage Sisters of Loretto directing parochial catechetical centers working with children of all ages, family groups, young peoples' groups, adult education. I wonder if this is the direction our apostolate will take?"265 The Sisters' engagement with the nouvelle théologie had laid the groundwork for the more significant and far reaching changes to their lives that would be enacted in response to the decrees of the Second Vatican Council. These post-Conciliar changes will be the subject of the next section.

\footnotetext{
${ }^{264}$ Kristin McNamara to Mary Luke Tobin, February 17, 1962. Loretto Archives, Loretto Motherhouse, Nerinx, KY.

${ }^{265}$ Anna Barbara Brady to Mary Luke Tobin, February 18, 1963. Loretto Archives, Loretto Motherhouse, Nerinx, KY.
} 


\section{CHANGES OF THE POST-CONCILIAR ERA AND IMPACT OF NOUVELLE THÉOLOGIE}

When the Second Vatican Council convened in the fall of 1962, Catholics throughout the world waited to see what changes its outcomes would bring. The Sisters of Loretto, too, followed news of the Council proceedings with great interest and anticipation. Because of their early engagement with nouvelle théologie, as these ideas gained more broad acceptance through the Council, the Sisters of Loretto were already adjusting their community life and work to reflect changing priorities, both before and during the Council sessions. The outcomes of the Council gave more concrete impetus to continue this process and to allow for more far-reaching changes to their community life in the years that followed. In this section, I will discuss some of the specific changes the Sisters of Loretto made to their rules and customs, providing examples of the ways individual Sisters experienced these changes personally. Additionally I will demonstrate how the rule changes enacted by the Sisters of Loretto reflect the influence of nouvelle théologie's main themes: the call to réssourcement, the overlapping relationship of the natural and supernatural, and the importance of religious engagement with the issues of modern life.

One of the primary aims of the nouveaux théologiens was to encourage réssourcement - a return to original sources of Christian inspiration, including the Bible and the writings of early Church fathers. Already engaging with the work of the 
nouveaux théologiens in the 1950s, the Sisters of Loretto began making changes to their spiritual practices that reflected this movement's influence. One of the earliest examples was their experimentation with, and eventual adoption of a simplified form of the Divine Office (also called the Liturgy of the Hours, or the Breviary) for their corporate prayer times, during the mid-1950s. ${ }^{266}$ The Divine Office is the "official prayer" of the Catholic Church, practiced daily by priests. It consists of 7 canonical hours, or appointed times of prayer throughout the day. Unlike the Sisters' earlier practice, the Divine Office is based on readings from the Psalms and other books of the Bible, and can also include the writings of saints or Church fathers. ${ }^{267}$ Before adoption of the Divine Office, the Sisters of Loretto still gathered within their convents for coporate prayer several times per day, but typically recited prayers such as the Holy Rosary, the Our Father, various novenas and litanies, and other prescribed prayers to mark the feasts and holy days of the Church year. ${ }^{268}$ While such prayers are approved by the Church and the faithful are encouraged to use them, most are not direct quotations from Scripture, or from the writings of saints and Church fathers. The Sisters' decision to begin using the Divine Office, with its basis in the Biblical literature and church history, reflects their

\footnotetext{
${ }^{266}$ Helen Sanders, More Than A Renewal, Loretto Before and After Vatican II: 19521977 (Nerinx, KY: Sisters of Loretto, 1982), 20-22.

Elaine Prevallet, "The Changes - 1952 - 1972: Personal Transformation," in A Century of Change 1912 - 2012: Loretto's Second Century, ed. Patricia Jean Manion (Point Reyes Station, CA: Chardon Press, 2012), 33.

267 "What is Divine Office," Divine Office Ministry, accessed February 17, 2020, https://divineoffice.org/liturgy-of-the-hours/.

${ }^{268}$ Sanders, More Than A Renewal, $20-22$.
} 
desire to connect more directly with these sources of inspiration, as advocated in the nouvelle théologie. ${ }^{269}$

The Sisters of Loretto also sought to provide réssourcement to members in other ways. Leaders hired some of the best available Biblical scholars and theologians to provide instruction to young Sisters in the novitiate, and to conduct summer Scripture courses, which all members were encouraged to attend if possible. ${ }^{270}$ Maureen O'Connell and Maureen Spero both remember being enriched by their classes with Father Carroll Stuhlmueller, a Passionist priest and internationally recognized Old Testament scholar. ${ }^{271}$ Father Thomas Merton, already a well-known writer and thinker, also spoke to the Sisters about prayer, encouraging them not to fixate on "perfect prayer," but rather to "get away from the scrupulosity of religion and embrace the real message." ${ }^{272}$ Some Sisters, as described previously, were sent abroad to study Scripture, theology, and religious education at some of the world's foremost Catholic institutions. In these ways, they sought to connect their own spirituality more directly to Scripture and the writings of early Church fathers.

Though teaching had been their collective apostolate since the order's founding in 1812, the Sisters of Loretto decided in 1968 that members would no longer be required to serve as teachers in Catholic schools. They were not alone in making this change, as

\footnotetext{
${ }^{269}$ Kristin McNamara interviewed by Carol Bolton, March 9, 2016. Loretto Motherhouse, Nerinx, KY.

${ }^{270}$ Sanders, More Than A Renewal, 20.

${ }^{271}$ Maureen O'Connell interviewed by Carol Bolton, November 13, 2015, Loretto Jubilee Oral History Project, Kentucky Historical Society, Frankfort, KY. Marlene Spero interviewed by Eleanor Craig, SL, October 20, 2013, Loretto Oral History Project, Kentucky Historical Society, Frankfort, KY.

${ }^{272}$ Maureen O'Connell interviewed by Carol Bolton, November 13, 2015, Loretto Jubilee Oral History Project, Kentucky Historical Society, Frankfort, KY.
} 
many other women's orders, such as the Glenmary Sisters of Cincinatti and the Sisters, Servants of the Immaculate Heart of Mary of Los Angeles, reached similar decisions regarding their traditional ministries. Nor was this change undertaken lightly: the Loretto Sisters reached their decision only after significant study and reflection on their founding documents, and the spirit embodied by the 3 young women who were the first Sisters of Loretto. This process of examining their order's history and original spirit reflects the influence of nouvelle théologie, and the call for réssourcement, both on the Sisters of Loretto and at the Vatican Council. Perfectae Caritatis, the Council document addressing the practices of religious institutes, instructed all orders to undertake such study, and to update their practices in keeping with the original spirit and motivations of their founder or foundress. ${ }^{273}$

Ultimately, the Sisters of Loretto determined that their foundresses had become teachers and established schools because education was one of the most pressing needs of the frontier community they lived in, and one they were well equipped to meet. The education of young children was also a socially acceptable ministry for the early Lorettines, in keeping with antebellum gender conventions. ${ }^{274}$ Education continued to be a pressing need as U.S. westward expansion continued, and Sisters of Loretto had worked diligently to ensure the children of frontier communities had opportunity to learn. In modern America, however, it was no longer clear that an apostolate devoted exclusively to Catholic education was the most effective way for them to serve their communities.

\footnotetext{
273 "Perfectae Caritatis," Vatican Archives, accessed February 17, 2020. http://www.vatican.va/archive/hist councils/ii_vatican council/documents/vatii decree 19651028 perfectae-caritatis_en.html. ${ }^{274}$ See O’Daniel, Southern Veils, 68-71.
} 
Because of the order's focus on improving Sisters' own educational opportunities, starting in the 1950s, many had by this time obtained advanced degrees and were equipped to serve in a variety of fields, or to teach outside of exclusively Catholic schools. Moreover, they found increasing opportunities to use their skills, as new career paths opened to women throughout the later twentieth century. The Sisters were also increasingly aware of the diverse variety of problems and needs facing their communities, such as growing poverty, racial injustice, labor disputes, opposition to the Vietnam War, and the proliferation of nuclear weapons. In consideration of all this, the Sisters determined together that in order to respond effectively to the variety of pressing needs facing the modern world, each member of the congregation should determine individually how best to use her unique gifts, abilities, and education. Sisters who wished to continue teaching could certainly do so, while other Sisters could pursue ministries in other fields. In either case, Sisters became responsible for securing employment for themselves, rather than receiving an assignment from a Superior. ${ }^{275}$

This decision represented a watershed moment for the Sisters of Loretto, one which fundamentally altered the course of many Sisters' lives and careers. Its impact was also magnified by its coinciding with the removal of some additional rules and customs that set the Sisters apart from secular life, both symbolically and physically. These decisions reflected another of nouvelle théologie's primary aims: reconnecting Catholic faith with daily life by emphasizing the overlapping relationship of the natural with the

\footnotetext{
${ }^{275}$ Marian McAvoy, "Taking Hold of Decision-Making Personally and Communally," in A Century of Change 1912 - 2012: Loretto's Second Century, ed. Patricia Jean Manion (Point Reyes Station, CA: Chardon Press, 2012), 62-69.

See also: Cecily Jones, "Luke and the Doors to Change," in A Century of Change 1912 - 2012: Loretto's Second Century, ed. Patricia Jean Manion (Point Reyes Station, CA: Chardon Press, 2012), 54-55.
} 
supernatural, or the secular with the holy. One of the most noticeable changes, to those outside the order, was that many Sisters of Loretto stopped wearing the traditional habit and veil that had visually signified them as women religious, choosing to adopt contemporary dress instead. Though this highly visible change took place in 1968, the process of change had begun well before Vatican II, with the order seeking to modify their habit to allow for the demands of life in the modern world. In 1953, for example, leadership authorized a modification of the order's distinctive veil, so that it did not impede the wearer's peripheral vision. This modification ensured that a Sister of Loretto, or a Superior, would be able to drive a vehicle if needed, as mobility became increasingly necessary during the mid-twentieth century. ${ }^{276}$

The Sisters of Loretto began to contemplate more significant changes to their religious habit in the early 1960s, while the Vatican Council was in session, but before any modernization efforts had been specifically directed via Perfectae Caritatis. A study was undertaken, input obtained from congregation members, as well as clergy and lay friends and supporters. This process revealed broad support for updating the Loretto habit to a more modern style, that would allow laypeople to relate more easily to the Sisters, and allow the them to minister more effectively in a modern context. ${ }^{277}$ The order gave much consideration to the idea of updating their habit, even commissioning potential designs and allowing smaller communities of Sisters to experiment with wearing them, to generally positive response. ${ }^{278}$ However, the congregation ultimately decided to allow

\footnotetext{
276 Sanders, More Than A Renewal, 19-20

277 ibid., 71-77

278 ibid., 116-120
} 
members to adopt contemporary dress of their own choosing, with the understanding that it should be modest and simple in keeping with their vows of chastity and poverty. ${ }^{279}$

Much like their decision to broaden their apostolate beyond teaching, the Sisters reached this decision together, and made dress a matter of individual decision - members who wished to continue wearing the habit could certainly do so, but it was no longer required of everyone in the community. Also like their decision to broaden their apostolate, the decision to allow contemporary dress had profound implications for Sisters' day to day experiences, and their interactions with people outside the Congregation.

The religious habit had served as a visual and symbolic division between the Sisters and the laypeople they interacted with in their course of their work. It set them conspicuously apart, identifying them with the holiness claimed by the Church, distinguishing them from the "common" experiences of secular life. The habit created a perception of difference, remoteness, that made it difficult for laypeople to relate easily to them. Wearing the habit necessarily foregrounded Sisters' religious status over their individual personalities and experiences, as well as the human experience of anyone with whom they might interact. Sister Maureen McCormack, studying at Denver University in the 1960s, remembers hearing another student say "There it is," when she walked by in her habit, not even seeming to recognize her as a person. ${ }^{280}$ John O’Bryan, a lay professor at St. Louis University and acquaintance of the Sisters of Loretto, expressed it this way: "I feel that both the layman and the sister play roles when they converse. I

\footnotetext{
${ }^{279}$ Ibid., 125-126.

${ }^{280}$ Maureen McCormack interviewed by Rosie Moosnick, April 22, 2012, Loretto Jubilee Oral History Project, Kentucky Historical Society, Frankfort, KY.
} 
speak and act as I think I am expected to speak and act in the presence of a sister. The sister speaks and acts as she thinks the layman expects her to speak and act. Thus neither one's real self is portrayed in the exchange. I believe the habit is one obstacle to true interpersonal relationships., 281

The Sisters' decision to remove this distinction reflected the influence of nouvelle théologie's emphasis on reconnecting the secular with the holy, or the natural with the supernatural, because it allowed the Sisters to identify and connect more easily and meaningfully with their constituencies, and to work in situations where religious clothing might be impractical or unwelcome. This was an important consideration as they moved into new forms of ministry and activism, outside their traditional roles as Catholic educators. Rose Colley was in the majority of Loretto Sisters who discontinued wearing their religious habits, in favor of modern clothing. Though some clergy objected to the change, she perceived an immediate positive difference in the way laypeople responded to her, and felt more at ease interacting with them as she went about her work. ${ }^{282}$

Most students' families were supportive of the Sisters decision. Joan Spero and Mary Ellen McElroy were both teaching at St. Rose of Lima in St. Louis, Missouri, when they first changed out of their habits. To ease the shock for their school families, the Sisters held an open house so everyone could come and see what they would look like. ${ }^{283}$ At first, the Sisters were still required to wear their habits to events outside their school or community setting, however, making the initial period of change feel somewhat

\footnotetext{
${ }^{281}$ Sanders, More Than A Renewal, 77.

${ }^{282}$ Rose Colley interviewed by Carol Bolton, June 8, 2015, Loretto Jubilee Oral History Project, Kentucky Historical Society, Frankfort, KY.

${ }^{283}$ Mary Ellen McElroy interviewed by Doris Malkmus, August 24, 2012, Loretto Jubilee Oral History Project, Kentucky Historical Society, Frankfort, KY.
} 
"schizophrenic." Spero, then taking evening courses at St. Louis University, recalls having dreams about not being able to find her habit when needed. ${ }^{284}$ Some older Sisters, who had worn the habit for many years, found this change more difficult than the younger members of the community, who largely welcomed it. Some chose to remain in the habit, but many others made the effort to change along with the Congregation. Georgeann Hanson remembers an older Sister in her Mobile community at the time. Already in her seventies, this Sister needed help to purchase appropriate clothing and have her hair done, after wearing the prescribed habit and veil for so many years. She told her community, however, "I have always done what Loretto has asked me to do, so I will do it now. 285

Broadening their apostolate and adopting contemporary dress brought the Sisters of Loretto into greater contact with the secular world, taking them outside of their traditional spheres. In 1970, they took the further step of inviting non-religious individuals to join them in their work through co-membership in the community. Comembership began as a way to provide former congregation members, who had left the community, with a way to retain a close association and involvement with the Sisters of Loretto. ${ }^{286}$ In the decade following Vatican II, as numerous changes were implemented across Catholic life, a significant number of religious, both women and men, requested dispensation from their vows and separated from their institutions.

\footnotetext{
${ }^{284}$ Joan Spero interviewed by Eleanor Craig, October 23, 2013, Loretto Jubilee Oral History Project, Kentucky Historical Society, Frankfort, KY.

${ }^{285}$ Georgeann Hanson interviewed by Doris Malkmus, April 23, 2012, Loretto Jubilee Oral History Project, Kentucky Historical Society, Frankfort, KY.

${ }^{286}$ Martha Alderson, "The Loretto Community: Sisters of Loretto and Co-Members of Loretto," in A Century of Change 1912 - 2012: Loretto's Second Century, ed. Patricia Jean Manion (Point Reyes Station, CA: Chardon Press, 2012), 96 - 98.
} 
The Sisters of Loretto were not excepted from this trend, as numerous members left the congregation between 1967 and 1970, for a variety of reasons. In a widely publicized early example, Sister Jacqueline Grennan, then president of Webster College, requested dispensation from her vows in 1967. Grennan had just spent two years battling ecclesiastical officials who opposed her efforts to transfer the college to ownership by a lay board, separating it from Church control. ${ }^{287}$ Teresa Kinealy also began to struggle with commitment to her vows. ${ }^{288}$ Joan Blessum Mahan felt that the sense of stability and community she had enjoyed in Loretto prior to Vatican II was breaking down with all the changes and additional freedoms. ${ }^{289}$ Therese Delich Stawowy and Marriane Novak Houston both realized that they wanted to be married and raise families. ${ }^{290}$

Congregational leaders strove to handle each situation with compassion, keeping lines of communication open with former Sisters whenever possible. Jacqueline Grennan actually remained in her post as Webster College president for two years after renouncing her vows, to guide the institution's transfer to lay leadership. When she married Paul Wexler in 1969, the couple held their wedding ceremony in the college's music

\footnotetext{
${ }^{287}$ Paul Vitello, “Jacqueline G. Wexler, ex-nun who took on Church, dies at $85, \mathrm{New}$ York Times, January 24, 2012. Accessed July 28, 2020, https://www.nytimes.com/2012/01/25/nyregion/jacqueline-g-wexler-ex-nun-who-tookon-church-dies-at-85.html.

${ }^{288}$ Theresa Kinealy interviewed by Eleanor Craig, February 17, 2014, Loretto Jubilee Oral History Project, Kentucky Historical Society, Frankfort, KY.

${ }^{289}$ Joan Blessum Mahan interviewed by Rose Moosnick, April 24, 2012, Loretto Jubilee Oral History Project, Kentucky Historical Society, Frankfort, KY.

${ }^{290}$ Therese Stawowy interviewed by Rosie Moosnick, April 24, 2012, Loretto Jubilee Oral History Project, Kentucky Historical Society, Frankfort, KY. Marianne Novak Houston interviewed by Fernanda Perrone, April 23, 2012, Loretto Jubilee Oral History Project, Kentucky Historical Society, Frankfort, KY.
} 
building. ${ }^{291}$ In 1970, Judy Ford realized that she no longer wanted to be "public representative of the Church," but she did not wish to completely cut ties with Loretto, having been a vowed member for over 15 years. With help from Helen Sanders, Ford proposed a "structure with Loretto that provided for a non-vowed community relationship." Later that year, Therese Delich Stawowy, Jeanine Swift, and Judy Ford herself re-established their connection with Loretto in this way.

Co-membership, as this relationship was called, allowed these former Sisters to participate in the life of the community again by attending gatherings and retreats, serving on committees, and working cooperatively with the Sisters in their peace and social justice efforts. Though the Sisters of Loretto were among the early communities to create such a structure, other women's orders began to adopt similar programs throughout the 1970s in response to the significant numbers of women leaving vowed membership. In Loretto model, no specific qualifications for co-membership were defined, allowing it to be open to those who had never been vowed members of the Congregation, including men, and individuals of other faith traditions. ${ }^{292}$ Former Sister Magdalena McCloskey and her husband were the first married couple to join the community through comembership. ${ }^{293}$ Jacqueline Grennen Wexler and her husband also joined the community as co-members, maintaining a strong relationship with Loretto throughout their lives. ${ }^{294}$

291 "In Memory: Remembrance of the Life of Paul J. Wexler CoL," July 31, 2018. Accessed July 28, 2020, https://www.lorettocommunity.org/remembrance-of-the-life-ofpaul-j-wexler-col/.

${ }^{292}$ Martha Alderson, "The Loretto Community," 98 - 99.

${ }^{293}$ Magdalena McCloskey interviewed by Rosie Moosnick, April 24, 2012, Loretto Jubilee Oral History Project, Kentucky Historical Society, Frankfort, KY.

294 “In Memory: Remembrance of the Life of Paul J. Wexler CoL," July 31, 2018. 
Though some Loretto co-members find the community on their own, many have been invited to join by vowed Sisters or other co-members with whom they have a prior relationship. ${ }^{295}$ Gordi Albie, for example, became a co-member after getting to know Anna Koop, P.J. Manion, and other sisters in the Denver area, as she volunteered with them at the local Catholic Worker House and took part in demonstrations at the Rocky Flats Plant. ${ }^{296}$ Anita Vargas, another co-member, is Bolivian. She befriended Mary Peter Bruce while working alongside her in the country's rural communities, and later went into hiding with Bruce and local Jesuits when her family members were arrested. ${ }^{297}$ Though the number of canonical Sisters of Loretto has declined, co-membership in the community has continued to grow, allowing the organization to continue active involvement in efforts to promote peace and justice. ${ }^{298}$ In 2012, Loretto's coordinator for co-membership, Martha Adler, described feeling "stretched for time" as she responded to a flood of new applications and requests for information about the community. ${ }^{299}$ This trend, of declining vowed membership combined with growing numbers of co-members, or "lay associates," is reflected in the experiences of many other U.S. religious orders,

${ }^{295}$ Mary Peter Bruce interviewed by Fernanda Perrone, April 24, 2012, Loretto Jubilee Oral History Project, Kentucky Historical Society, Frankfort, KY. Martha Alderson, "The Loretto Community," 102.

${ }^{296}$ Gordie Albi interviewed by Anna Powell, April 2012, Loretto Jubilee Oral History Project, Kentucky Historical Society, Frankfort, KY.

${ }^{297}$ Anita Vargas and Mary Peter Bruce interviewed by Doris Malkmus, April 24, 2012, Loretto Jubilee Oral History Project, Kentucky Historical Society, Frankfort, KY. ${ }^{298}$ Martha Alderson, "The Loretto Community," $101-104$.

${ }^{299}$ Maureen Fiedler, "The Evolution of the Committed Life in the $21{ }^{\text {st }}$ Century," National Catholic Reporter, June 8, 2013. Accessed August 2, 2020, https://www.ncronline.org/news/global-sisters-report/evolution-committed-life-21stcentury. 
both male and female. ${ }^{300}$ Loretto's model continues to be somewhat unique however, with regard to the degree of influence co-members may have within the community, a subject which has caused ongoing tension between Loretto leadership and the Vatican's Congregation for Institutes of Consecrated Life and Societies of Apostolic Life (CICLSAL). ${ }^{301}$

The decision to include "outsiders," or non-canonical individuals, in the work of Loretto also reflects the aims of nouvelle théologie, by further blurring distinctions between the sacred and the secular, or the supernatural and the natural world. Religious institutes like the Sisters of Loretto had been accorded greater holiness through their separation from the secular world. Even orders with active apostolates that brought them in regular contact with laypeople did not typically socialize outside their religious community, and Sisters were allowed only limited contact with family members and friends from their life before entering the convent. Sisters of Loretto were allowed a home visit only once every three years. ${ }^{302}$ In the event that a Sister made the decision to leave the order, her departure was a quiet, almost secretive affair, and remaining Sisters maintained no contact with her. ${ }^{303}$ With the creation of co-membership, the Sisters of

${ }^{300}$ Zoe Ryan, “Associates embrace orders' charisms," National Catholic Reporter, September 27, 2011. Accessed August 2, 2020, https://www.ncronline.org/news/associates-embrace-orders-charisms.

${ }^{301}$ Ann Carey, "Vatican calls Loretto head to Rome to discuss Sisters' 'dissent,"” National Catholic Register, June 14, 2016. Accessed August 2, 2020, https://www.ncregister.com/blog/ann-carey/vatican-summons-loretto-president-to-rometo-discuss-sisters-positions-of-d.

${ }^{302}$ Rosemary Wilcox interviewed by Doris Malkmus, April 22, 2012, Loretto Jubilee Oral History Project, Kentucky Historical Society, Frankfort, KY.

${ }^{303}$ Marion Golden Curtis, "Leave-Taking," in Voices from Silence: A Loretto Patchwork, ed. Sandy Ardoyno et. al. (Nerinx, KY: Sisters of Loretto, 2012), 50-53.

See also: Martha Alderson, "The Loretto Community," 97. 
Loretto invited non-canonical individuals into their community - not simply as observers or "associates," but as active participants in the spiritual life and mission of the organization - erasing much of the former separation between themselves and the secular world. In so doing, they also provided an outlet for Catholic parishioners, as well as nonCatholics, to put faith into practice, reconnecting theology with lived experience.

This desire - to reconnect theology with lived experience - also informed another of nouvelle théologie's main themes: encouraging religious engagement with the issues of modern life. This aspect of nouvelle théologie inspired some of the most far-reaching changes the Loretto Sisters experienced, and it continues to influence their community life in the present. Beginning in the 1960s, many Sisters of Loretto were increasingly and publicly involved with some of the most pressing social and political issues of the late $20^{\text {th }}$ century. Through their involvement in the Civil Rights movement, labor disputes, the women's movement, and efforts to end the Vietnam War and halt the proliferation of nuclear weapons, the Sisters of Loretto became advocates for social justice and nonviolence. As these issues commanded more of community members' time and attention, the Sisters evolved from living generally quiet and private lives within the convent setting, to being, in some cases, quite outspoken public figures. As such, they took bold stands that sometimes drew objections from Catholic parishioners, or brought them into conflict with civil and ecclesiastical authorities.

Sisters of Loretto participated in civil rights advocacy of both national and local significance. In March 1965, Therese Stawowy (then Sister Ann Christopher) and Christine Nava (then Sister Mary Christine) were given permission to travel to Selma, Alabama, along with several priests from their St. Louis diocese, to take part in a series 
of highly publicized civil rights demonstrations. Sister Antona Ebo, one of the first black women accepted into the Sisters of Mary (now the Franciscan Sisters of Mary), was also a part of this delegation from St. Louis, and was the only black Catholic Sister to participate in the Selma marches. ${ }^{304}$ Fellow Sisters of Loretto Maureen Smith and Judith Dillon were also in attendance at Selma, traveling from Kansas City with a group of religious and other activisits, at the request of the Catholic Interracial Council. ${ }^{305}$

These Sisters were among thousands of religious leaders and social activists who flocked to the city to join in support of the demonstrations, after Alabama state troopers attacked a peaceful group, led by Dr. Martin Luther King, Jr., attempting to march from Selma to Montgomery, Alabama. The Sisters hoped that their visible presence (still clad in religious habits at this point) would lend moral authority to the marchers' cause, increasing pressure on state and national leaders to bring an end to racial discrimination. On a more personal level, the Sisters also felt it was important show their African American students and their families that they were willing to fight alongside them for civil rights. ${ }^{306}$ At the time, not everyone in the congregation or the wider St. Louis community felt that it was appropriate for women religious to take part in such demonstrations. Therese Stawowy received many critical letters after returning home, and

\footnotetext{
${ }^{304}$ Alex Brandt, "St. Louis nun relives Civil Rights march," The Webster Journal, February 16, 2011. Accessed July 20, 2020, http://websterjournal.com/2011/02/16/stlouis-nun-relives-civil-rights-march/.

${ }^{305}$ Maureen Smith interviewed by Eleanor Craig, May 6, 2012, Loretto Jubilee Oral History Project, Kentucky Historical Society, Frankfort, KY.

${ }^{306}$ Therese Stawowy interviewed by Rosie Moosnick, April 24, 2012, Loretto Jubilee Oral History Project, Kentucky Historical Society, Frankfort, KY.

See also: Sisters of Selma: Bearing Witness to Change, directed by Jayasri Hart (2007; Arlington, VA: PBS Home Video, 2016), DVD.
} 
remembers that "they shook me up."307 She also recalls that "a couple of times we were asked not to speak at events after we were invited."

During the 1960s, Sisters teaching at Loretto High School and Christ the King School in Louisville, Kentucky, also faced some local resistance as they participated in civil rights demonstrations and also took an active role in the West End Community Council (WECC). This multiracial organization was working at the time to help facilitate the process of integration and to combat "white flight" as more African American families moved into formerly all white neighborhoods in West Louisville. ${ }^{308}$ Pauline Marie Smith, Rose Colley, and Maureen O'Connell regularly attended their meetings and helped to organize community events. They welcomed the influx of African American students into their school, even as many white families relocated to the suburbs. ${ }^{309}$ While not all of these students were necessarily professing Catholics, Louisville, and Kentucky more broadly, have historically had a significant black Catholic population, some of whom are descendants of enslaved people who adopted the Catholicism practiced by their enslavers. ${ }^{310}$ Prior to the demographic shifts of the 1960s, West Louisville boasted 17

\footnotetext{
${ }^{307}$ Colleen Dulle, 'If St. Louis is 'the new Selma,' what role will Catholics play in racial reconciliation," America Magazine - The Jesuit Review, October 3, 2017. Accessed July 20, 2020, https://www.americamagazine.org/politics-society/2017/10/03/if-st-louis-newselma-what-role-will-catholics-play-racial.

${ }^{308}$ Tracy K'Meyer, "The Battle for Open Housing," in Civil Rights in the Gateway to the South: Louisville, Kentucky, 1945 - 1980 (Lexington, KY: University Press of Kentucky, 2009), 114.

${ }^{309}$ Maureen O'Connell interviewed by Carol Bolton, November 13, 2015, Loretto Jubilee Oral History Project, Kentucky Historical Society, Frankfort, KY.

Rose Colley interviewed by Fernanda Perrone, April 2012, Loretto Jubilee Oral History Project, Kentucky Historical Society, Frankfort, KY.

${ }^{310}$ See the documentary film Facing an Uncomfortable Truth, directed by Stephen Crump, for an exploration of the experiences and contributions of black Catholics in Kentucky history. https://www.ket.org/program/facing-an-uncomfortable-truth/.
} 
Catholic parishes and 21 Catholic schools. Of these, one parish and two schools - a grade school and a high school - were specifically for African Americans, while all others served white families. ${ }^{311}$ The efforts of the Sister-teachers at Loretto High School and Christ the King School were motivated by their desire to promote racial equality both within Catholic life and the wider secular society.

O'Connell, who taught Social Studies at Loretto High School, sought to make her curriculum more inclusive by seeking a better understanding of African American history in order to teach more effectively. ${ }^{312}$ She also worked to ensure her students' understanding of current events, and exposed them to a variety of perspectives by regularly inviting local activists into her classroom to speak. Some parents objected to this practice, particularly when an activist who had visited the class was arrested shortly afterward. O'Connell credits Frances Jane O’Toole, her Superior at the time, with shielding her from much of the pushback, consistently supporting her teaching methods in spite of outside criticism. ${ }^{313}$

Sisters of Loretto living in Mobile, Alabama during the 1960s also faced resistance from their local archbishop, Monseigneur Stuardi, who forbade all the religious in his diocese from participating in any civil rights marches. Sisters Sandy Ardoyno and Georgeanne Hanson, inspired by the Sisters marching at Selma, utlimately chose to defy

Also see Hannah O'Daniel's "Southern Veils: The Sisters of Loretto in Early National Kentucky" (M.A. Thesis, University of Louisville, 2017), for more on Catholic slave ownership in early Kentucky (pgs. 28-37).

311 Jim Wayne, "Had Catholics lived their faith and not been racist, Louisville might be very different today," Louisville Courier-Journal, July 1, 2020. Accessed July 16, 2020, https://www.courier-journal.com/story/opinion/2020/07/01/catholics-racism-flight-westend-helped-segregate-louisville/5348572002/.

312Maureen O'Connell interviewed by Carol Bolton, November 13, 2015, Loretto Jubilee Oral History Project, Kentucky Historical Society, Frankfort, KY.

${ }^{313}$ Ibid. 
the Bishop's directive and attend local demonstrations. When they were arrested, the local Sisters of Loretto, along with the Brothers of the Sacred Heart, gathered funds to pay their bail. Though they expected trouble with the Bishop over their actions, it never came - he let the matter drop and never discussed it with them afterward. ${ }^{314}$

In addition to civil rights, Sisters of Loretto also advocated for workers' rights, as they attempted to combat harmful and exploitative corporate policies. Sisters Mary Jean Friel, Ruth Shy, and Guadalupe Arciniega traveled to California and served as full-time organizers for the United Farm Workers (UFW), who sought fair pay, better working conditions, and legal protections for farm laborers. ${ }^{315}$ Having these direct connections with the farm workers' movement helped ensure Loretto's support for UFW efforts on the local level. Interchange, the community's newsletter, provided a way to keep the whole community informed about the status of boycotts, strikes, and individual Sisters' activities. ${ }^{316}$ When the UFW called for a boycott of grocery stores who carried produce harvested by non-union laborers, the Sisters of Loretto became active supporters. Maureen O'Connell and others picketed Louisville grocery stores carrying non-UFW fruits and vegetables, handing out literature to customers about the farm workers' plight, and encouraging them to shop elsewhere. ${ }^{317}$ Pam Solo and Mary Bundy led similar

\footnotetext{
${ }^{314}$ Sandy Ardoyno interviewed by Eleanor Craig, March 8, 2014, Loretto Jubilee Oral History Project, Kentucky Historical Society, Frankfort, KY. Georgeanne Hanson interviewed by Doris Malkmus, April 23, 2012, Loretto Jubilee Oral History Project, Kentucky Historical Society, Frankfort, KY.

${ }^{315}$ Cecily Jones, "Crossing the Line: Loretto and Social Protest," in Naming Our Truth: Stories of Loretto Women (Inverness, CA: Chardon Press, 1995), 162-167. ${ }^{316}$ Ibid.

${ }^{317}$ Maureen O'Connell interviewed by Carol Bolton, November 13, 2015, Loretto Jubilee Oral History Project, Kentucky Historical Society, Frankfort, KY.
} 
efforts in the Denver area. ${ }^{318}$ The UFW later boycotted E\&J Gallo Wines over the company's unfair labor practices. Pat McCormick and Cecily Jones supported this action as well, and faced arrest as they picketed outside a Denver-area liquor store. ${ }^{319}$

In a later example, the Sisters of Loretto took action against the Blue Diamond Mining Company, whose poor safety standards led to a 1976 accident at a mine in southeastern Kentucky, in which 26 miners were killed. In cooperation with other religious activist groups, the Sisters of Loretto (through the order's investment committee) began purchasing stock in the company. As principal shareholders, they hoped to exert pressure on the company to change their business practices and adopt greater transparency. The mining company refused to register Loretto's stock to its new owners, arguing that they had purchased the stock inappropriately - for reasons other than financial gain. The Sisters, along with their partner organizations, then sued the Blue Diamond Company - and won. The court ruled that the company's shareholders had the right to assert their views to management. The Blue Diamond Company ultimately was forced to adopt greater transparency and enact significant changes to their business practices, resulting in safer working conditions for the miners. ${ }^{320}$

\footnotetext{
${ }^{318}$ Cecily Jones, "Crossing the Line."

${ }^{319}$ Ibid.

${ }^{320}$ Ben A. Franklin, 'Nuns Sue to Force 'Accountability' on Coal Company," New York Times, September 20, 1979. https://www.nytimes.com/1979/09/20/archives/nuns-sue-toforce-accountability-on-coal-company.html.

Ward Sinclair and Bill Bishop, "Justice Moves Slowly in Mine Disaster," Washington Post, March 9, 1980. https://www.washingtonpost.com/archive/politics/1980/03/09/justice-moves-slowly-inmine-disaster/7b586840-d171-4780-98f6-b5d8acc6059f/.

Severyn T. Bruyn, The Field of Social Investment (Cambridge, UK: Cambridge University Press, 1987), 33, https://books.google.com/books?id=TuHG8m5zN50C\&pg=PA33\&lpg=PA33\&dq=Sister
} 
Some members of the Loretto congregation also actively supporterd the women's movement of the 1960s and 70s. In particular, these Sisters publicly expressed their support for women's reproductive rights, in spite of the Catholic Church's official opposition to abortion. Six Sisters of Loretto - Mary Ann Cunningham, Mary Louise Denny, Maureen Fiedler, Pat Kenoyer, Ann Patrick Ware, and Virginia Williams - were among 24 women religious who signed their names to an advertisement that ran in the New York Times on October 7, 1984, entitled "A Diversity of Opinion Regarding Abortion Exists Among Committed Catholics. ${ }^{, 321}$ It included a brief statement on abortion, which included the following: "Statements of recent Popes and of the Catholic hierarchy have condemned the direct termination of pre-natal life as morally wrong in all circumstances. There is a mistaken belief in American society that this is the only legitimate Catholic position. ${ }^{, 322}$ Marian McAvoy, Loretto's President at the time, faced intense pressure from Rome to punish the six Sisters, unless they publicly recanted their statements. McAvoy resisted this course of action, finding "no cause" for discipline, but Rome refused to accept her decision. In 1986, representatives from the Vatican's Congregation for Religious and Secular Institutes finally agreed to meet with Loretto $\underline{\mathrm{s}+\text { of }+ \text { Loretto }+ \text { sue }+ \text { Blue }+ \text { Diamond }+ \text { Mines\&source }=\text { bl\&ots }=x 5 \text { VfRYn63R\&sig }=\text { ACfU3 }}$ U2orVBWXliptOWLyTeIR4rwqZv8mA\&hl=en\&sa $=$ X\&ved=2ahUKEwir4uDfwtbnAh XPGM0KHVS7DA4Q6AEwA3oECAoQAQ\#v=onepage\&q=Sisters\%20of\%20Loretto\% 20sue\%20Blue\%20Diamond\%20Mines\&f=false.

${ }^{321}$ Also among the ad's signers is Sr. Jeannine Gramick, a member of the School Sisters of Notre Dame (SSND). Gramick was a member of this order for almost 4 decades, but resigned after SSND leaders, under of pressure from the Vatican, asked her to discontinue her involvement in ministry to LGBTQ+ Catholics. She chose to join the Sisters of Loretto, who were willing to support her efforts to be a voice for LGBTQ+ people in the Catholic Church. See Jeannine Gramick, interviewed by Doris Malkmus, April 23, 2012, Loretto Jubilee Oral History Project, Kentucky Historical Society, Frankfort, Kentucky.

${ }^{322}$ The full text of the advertisement is available here: https://documents.alexanderstreet.com/d/1000679104. Accessed July 20, 2020. 
community members face-to-face, in the hope of reaching a mutually agreeable solution. The six Sisters agreed to sign the public statement that resulted from this discussion, which affirmed Church teaching on the sanctity of human life, but did not specifically disavow their support for reproductive choice. ${ }^{323}$

Sisters of Loretto also strongly supported the ordination of women into the Catholic priesthood, again finding themselves at odds with Church officials, who maintained that only men could serve the office of priest. From the time of her attendance at the Vatican Council, Mary Luke Tobin began to advocate for women to be fully included in all ministries of the Church. She felt that their exclusion from any part of Church life, or relegation to separate roles, represented a form of gender discrimination that was not in keeping with the example of Christ found in Scripture. ${ }^{324}$ Tobin applauded the efforts the Women's Ordination Conference (WOC), formed in 1975, which works toward ordaining women as deacons, priests, and bishops, and creating a more inclusive and accountable Church. ${ }^{325}$ Other Sisters and co-members of Loretto have also played central roles in the WOC since its inception, including Joan Campbell, worked full time

${ }^{323}$ Marian McAvoy, "The Only Way Available," in Naming Our Truth: Stories of Loretto Women, ed. Ann Patrick Ware (Inverness, CA: Chardon Press, 1995), 207-228. See also: Mary Ann Cunningham, "From Silence to Speech: Finding My Voice," in Naming Our Truth: Stories of Loretto Women, 151-155.

${ }^{324}$ Mary Luke Tobin, "Female and Catholic: An Interview with Sister Mary Luke Tobin, S.L., U.S. Catholic, April 1987. https://www.uscatholic.org/church/2012/09/female-andcatholic-interview-sister-mary-luke-tobin-sl.

See also: Mary Luke Tobin, "Women in the Church Since Vatican II," America Magazine, November 1, 1986. https://www.americamagazine.org/issue/100/womenchurch-vatican-ii.

${ }^{325}$ Mary Luke Tobin, "Doors to the World," in Midwives of the Future: American Sisters Tell Their Story, ed. Ann Patrick Ware (Kansas City, MO: Leaven Press, 1985), 192 193.

“About Our Work," About Us, Women's Ordination Conference, accessed February 18, 2020. https://www.womensordination.org/about-us-import/about-our-work/. 
as coordinator for the WOC's first conference gathering in Detroit. ${ }^{326}$ She recruited Rose Colley, another Sister of Loretto, to help facilitate that first meeting. Colley remained involved for many years helping to organize and facilitate local groups. ${ }^{327}$ Sylvia Sedillo helped to guide the organization in its early days as a member of its "Core Commission," and co-member Ruth Fitzpatrick served as WOC President in the 1980s and early 90 s. ${ }^{328}$ Loretto continues to support the WOC's efforts today, with Sister Jeannine Gramick currently serving as a member of their National Advisory Board. ${ }^{329}$

The Sisters' support for marginalized communities further translated into staunch opposition to U.S. militarism in Southeast Asia as well as Latin America. Marie Ego and numerous other Sisters of Loretto risked arrest as they participated in peace rallies, civil disobedience, and other demonstrations against U.S. involvement in the Vietnam War. In an early example, Sister Joann Malone was arrested in March 1969, along with other members of the "D.C. Nine," for her part in ransacking the Washington offices of the Dow Chemical Company, manufacturers of the napalm gas used by U.S. troops in Vietnam. Loretto leadership supported Malone's freedom of conscience, refusing to dismiss her from her teaching position in spite of pressure from parents at Nerinx Hall,

\footnotetext{
${ }^{326}$ Mary Ann Cunningham, "Loretto Women's Network: Are We There Yet?" in A Century of Change, 1912-2012: Loretto's Second Century, ed. Patricia Jean Manion (Point Reyes Station, CA: Chardon Press, 2012), 195.

${ }^{327}$ Rose Colley interviewed by Fernanda Perrone, April 22 2012, Loretto Jubilee Oral History Project, Kentucky Historical Society, Frankfort, KY.

${ }^{328}$ Sylvia Sedillo interviewed by Rosie Moosnick, April 23, 2013, Loretto Jubilee Oral History Project, Kentucky Historical Society, Frankfort, KY.

Rose Colley interviewed by Fernanda Perrone, April 22, 2012, Loretto Jubilee Oral History Project, Kentucky Historical Society, Frankfort, KY.

Mary Jeremy Daigler, Incompatible With God's Design: A History of the Women's Ordination Movement (Lanham, MD: Rowman \& Littlefield Publishing Group, 2012), 85 -86 .

329 "National Advisory Board," Leadership, Women's Ordination Conference, accessed February 16, 2020, https://www.womensordination.org/leadership/.
} 
where Malone was then a faculty member. ${ }^{330}$ Mary Luke Tobin, Loretto's president at the time of Malone's imprisonment, was herself arrested in 1972, at the Capitol rotunda in Washington, D.C., as she and other religious leaders conducted a prayer service following efforts to spur Congressional action to end the war. ${ }^{331}$ In an earlier effort, Tobin actually traveled to Saigon in 1970 as part of a delegation to promote dialogue and peace. $^{332}$ Sister Maureen O'Connell remembers reading multiple books on Vietnam as a young Sister, to try and understand the conflict and the United States' role in it.

O'Connell's study led her to conclude that U.S. involvement was morally wrong, and she too became a regular attendee at anti-war protests, joining the Louisville Peace League the very next day. ${ }^{333}$

Sisters Mary Nell Gage and Susan Carol McDonnell responded to the conflict somewhat differently. They took action by traveling to Vietnam work in an orphanage, McDonnell as a nurse caring for abandoned and malnourished children, and Gage helping to facilitate overseas adoptions. They helped evacuate orphaned children from the country in 1975, before being evacuated themselves along with other American personnel, as the country fell to North Vietnamese forces. Upon returning to the United

\footnotetext{
${ }^{330}$ Helen Sanders, "Conflicting Values Surface, “ in More Than a Renewal, Loretto Before and After Vatican II: 1952 - 1977 (Nerinx, KY: Sisters of Loretto, 1982), 183 195.

${ }^{331}$ Mary Luke Tobin, "The Door of Social Justice: Vietnam and After," in Hope is an Open Door (Nashville, TN: Abingdon Press, 1981), 100.

${ }^{332}$ Cecily Jones, "Crossing the Line: Loretto and Social Protest," in Naming Our Truth: Stories of Loretto Women, ed. Ann Patrick Ware (Inverness, CA: Chardon Press, 1995), 168-179.

${ }^{333}$ Maureen O'Connell, interviewed by Carol Bolton, November 13, 2015. Loretto Jubilee Oral History Project, Kentucky Historical Society, Frankfort, KY.
} 
States, Gage began work with Lutheran Social Services of Denver, helping to resettle Vietnamese refugees in the United States. ${ }^{334}$

Other Sisters of Loretto began raising awareness about harmful U.S. policies they witnessed at work in Latin America. During the 1960s, the congregation sent personnel to serve missions in Bolivia, Peru, and Chile, in response to the Vatican's call for more religious to minister in this part of the world. ${ }^{335}$ Members and co-members also later ministered in El Salvador, Nicaragua, and Guatemala. ${ }^{336}$ These Sisters witnessed staggering economic inequality, in which a few wealthy elites typically dominated government and business, while the majority of people lived in poverty. Indigenous communities often suffered the worst. As the Sisters came to recognize, U.S. corporations, such as mining companies operating in Latin America, played a role in perpetuating these unjust systems. They made millions of dollars extracting valuable natural resources, while paying poor wages, forcing workers to tolerate unsafe conditions, and subjecting the local populace to environmental hazards. The U.S. government was

\footnotetext{
${ }^{334}$ Mary Nell Gage interviewed by Anna Powell, April 2012, Loretto Jubilee Oral History Project, Kentucky Historical Society, Frankfort, KY. Sue Carol McDonald, "Orphans in a Time of War, " in A Century of Change, 1912 2012: Loretto's Second Century (Point Reyes Station, CA: Chardon Press, 2012), 153 155.

${ }^{335}$ Cecily Jones, "Loretto Goes to South America," in A Century of Change, 1912 2012: Loretto's Second Century, ed. Patricia Jean Manion (Point Reyes Station, CA: Chardon Press, 2012), 135 - 136.

${ }^{336}$ Kathleen De Sutter Jordan, "At the Foot of the Cross: Remembering Ann Manganaro," Commonweal, August 30, 2016, https://www.commonwealmagazine.org/foot-cross.
}

Natalie Wing interviewed by Rosie Moosnick, April 22, 2012, Loretto Jubilee Oral History Project, Kentucky Historical Society, Frankfort, KY.

Gordie Albi interviewed by Anna Powell, April 2012, Loretto Jubilee Oral History Project, Kentucky Historical Society, Frankfort, KY.

Alicia Ramirez, "My Time in Nicaragua," in A Century of Change 1912 - 2012: Loretto's Second Century (Point Reyes Station, CA: Chardon Press, 2012), 141 - 142. 
also complicit. Due to fears about the spread of Communist ideology, the Nixon administration undermined popularly elected leftist leaders like Juan José Torres and Salvador Allende, indirectly supporting coups d'etat in which military leaders wrested control of government to rule as dictators. Some of these men, such as Bolivia's Hugo Banzer, actually received training in the United States, at the former School of the Americas (SOA) ${ }^{337}$ This training facility for Latin American military and police is funded by the U.S. Department of Defense and housed at Fort Benning, Georgia. The school is still in operation today as the Western Hemisphere Institute for Security Cooperation (WHINSEC). ${ }^{338}$

As Sisters like Eva Salas, Mary Peter Bruce, Maria Visse, and others reported back to the Loretto congregation about the injustices and violence they witnessed abroad, community members began to speak out against the government policies helping to support these situations in Latin America. ${ }^{339}$ Sisters began regularly participating in protests against the SOA, where they and other critics alleged that the curriculum included instruction in torture, and drew attention to former SOA students who had been accused of human rights violations, and gone on to positions in undemocratic government

\footnotetext{
${ }^{337}$ Pat McCormick, "Experience in Bolivia Changed the Direction of My Life, in $A$ Century of Change, 1912 - 2012: Loretto's Second Century, ed. Patricia Jean Manion (Point Reyes Station, CA: Chardon Press, 2012), 136 - 137

Penny McMullen, "Lessons from Bolivia, "in A Century of Change, 1912 - 2012: Loretto's Second Century, ed. Patricia Jean Manion (Point Reyes Station, CA: Chardon Press, 2012), 137 - 139.

Kristin McNamara, "My Experience in Chile, "in A Century of Change, 1912 - 2012: Loretto's Second Century, ed. Patricia Jean Manion (Point Reyes Station, CA: Chardon Press, 2012), 139 - 140.

338 "What Is The SOA?" SOA Watch, accessed November 14, 2015, http://www.soaw.org/about-the-soawhinsec/what-is-the-soawhinsec.

${ }^{339}$ Eva Marie Salas interviewed by Fernanda Perrone, April 24, 2012, Loretto Jubilee Oral History Project, Kentucky Historical Society, Frankfort, KY.
} 
regimes in their home countries. ${ }^{340}$ These demonstrations continue annually into the present day, with Sisters and co-members of Loretto regularly in attendance, occasionally risking arrest for trespassing on federal property, as they peacefully enter the grounds at Fort Benning.

Tobin and other Sisters also risked arrest in their opposition to the proliferation of nuclear weapons throughout the late $20^{\text {th }}$ century. Cecily Jones and other Sisters of Loretto living in the Denver, Colorado, area frequently participated in public protests at the nearby Rocky Flats Plant, a nuclear weapons production facility. Loretto Sister Pam Solo helped to organize large scale protests there through her work with the American Friends Service Committee. Marie Ego, Mary Ann Cunningham, Penny McMullen, Pat McCormick, and Anna Koop were all arrested at different times for trespassing onto the property to pray or post signs. In addition to Rocky Flats, Sisters of Loretto engaged in direct action at numerous other nuclear and military facilities, and supported disarmament efforts such as the Nuclear Weapons Freeze Campaign, and the Great Peace March for Global Disarmament. ${ }^{341}$

These ongoing public efforts by the Sisters of Loretto to promote peace and social justice have become their hallmark -- their order's defining ethos -- providing the unity

\footnotetext{
${ }^{340}$ It should be noted that supporters of the school dispute the claims of SOA Watch and other critics, arguing that human rights training has been implemented, and that those involved in human rights violations did not do so as a result of training received at SOA/WHINSEC. See http://fas.org/irp/crs/soa.htm, for a thorough, if dated, report on the controversy, published by the Federation of American Scientists; and http://www.benning.army.mil/tenant/whinsec/hr.html, for the school's official description of its human rights related curriculum.

${ }^{341}$ Cecily Jones, "Crossing the Line: Loretto and Social Protest," in Naming Our Truth: Stories of Loretto Women, ed. Ann Patrick Ware (Inverness, CA: Chardon Press, 1995), 179-194.

Marie Ego interviewed by Eleanor Craig, March 5, 2014, Loretto Jubilee Oral History Project, Kentucky Historical Society, Frankfort, KY.
} 
and sense of shared purpose previously engendered by their common work of teaching, a shared schedule, and strict adherence to the community's particular rules and customs. Like many of the other changes enacted by the Sisters of Loretto in the wake of Vatican II, this shift in focus is reflective of the influence of nouvelle théologie - specifically, its emphasis on the need for religious engagement with the issues of modern life. While the Sisters had historically exhibited concern for the needs and welfare of the communities in which they operated schools, the post Vatican II era saw them begin to critically address deeper systemic issues that contributed to the problems they witnessed. Certainly, their efforts at advancing Sisters' education helped enable them in this. With many members pursuing or having obtained advanced degrees in a variety of fields, the Sisters of Loretto by the mid-1960s were, as a group, highly informed as to the social and political realities of the time. They also possessed the intellectual skill and academic backgrounds necessary to articulate their opposition to policies they believed to be immoral or unjust.

The strategies the Sisters employed - attendance at protest marches, challenging corporations in court, trespassing on federal property and risking arrest - would have been unthinkable for them only a few years prior to Vatican II. Through their engagement with nouvelle théologie, however, the Sisters found the spiritual imperative to act boldly. Though prayer and other traditional elements of Catholic spirituality continued to be an integral part of their lives, these public efforts to effect peace and justice became, in themselves, profoundly spiritual acts - a way of demonstrating devotion to Christ, by aligning with the values they believed he embodied, as depicted in the Gospels. In this way, the Sisters' activism also reflected nouvelle théologie's understanding of the overlap between sacred and secular, as their real-world actions took on spiritual significance. The 
movement's call to réssourcement is further evident in the Sisters' focus on peace and justice work, as their actions were predicated upon study of biblical accounts of the character and teachings of Christ.

As we have seen, the ideas of nouvelle théologie bore significant influence on the Loretto congregation's decisions in the wake of Vatican II, leading them to enact a broad series of changes to their way of life, and redirect the focus of their collective work. The Sisters' embrace of peace and justice activism, and their ongoing commitment to this work, represents perhaps the fullest expression of their engagement with nouvelle théologie, encompassing all three of its major themes: réssourcement, the overlapping relationship of the secular with the sacred, and the importance of religious engagement with the issues of modern life. Social and political activism have become a defining factor in the collective identity and mission of the Loretto Community, for both vowed Sisters and co-members. In this way, the ideas of nouvelle théologie continue to play a role in shaping the community's future. 


\section{CONCLUSION}

As the Sisters of Loretto worked to improve and expand educational opportunities for members of the congregation, their engagement with the ideas of nouvelle théologie helped to change their lives in profound ways, both as individuals and as a community. The nouveaux théologiens sought to restore vitality to Catholic faith by encouraging a return to original sources of Christian inspiration, including the Bible and the writings of early church fathers. They emphasized the presence of God in the world -- the spiritual overlapping with the natural -- and called for the Church to take a more active role in addressing the concerns of modern life. These ideas reshaped sisters' beliefs about themselves and their role as women religious, within the Catholic Church and the wider world. The influence of nouvelle théologie laid the spiritual groundwork for their response to the dictates of the Second Vatican Council, leading them to alter their community structure and rules, their spiritual practices, and the focus of their apostolate during the post-Conciliar years.

Throughout their two centuries of ministry, the Sisters of Loretto have continually exhibited a readiness to embrace "the next thing," whatever that may have been at different times. From their earliest days on the Kentucky frontier, they acted decisively in responding to the needs they encountered in the communities they served, and to broader

cultural and social trends over time. Continually migrating and expanding their work as the frontier pushed westward, the Sisters stood ready to provide education and spiritual 
formation to the many thousands of Catholic immigrant families entering the United States throughout the nineteenth and early twentieth centuries. They sought to provide the best possible education to young sisters, and to meet new demands for professionalism as teacher training standards became increasingly rigorous.

When it became apparent in the mid twentieth century that Sister-teachers across many religious orders were not receiving adequate training, the Sisters of Loretto were among the first to respond to calls for cooperation and change. Establishing a juniorate to allow their young sisters to complete bachelor's degrees, Loretto Sisters also played key roles in the newly established Sister Formation Conference and encouraged more community members to pursue additional training and advanced degrees. Sister Mary Luke Tobin, as Superior General, worked to bring her congregation into contact with emerging ideas in Catholic theology, sending Sisters to study with eminent scholars in Italy, Belgium, and France, and inviting leading theologians to visit and teach at the Loretto Motherhouse in Kentucky.

Given this history of continual action and adaptation, it becomes rather unsurprising that the Sisters of Loretto embraced the progressive ideas of nouvelle théologie so readily in the late 1950s and early 60 s, well before these concepts gained ecclesiastical legitimacy during the Second Vatican Council. Even so, the process was at first a halting one, as demonstrated by Sister-students in Europe who struggled to reconcile the hierarchy and formality to which they were accustomed with the new theological framework they were encountering. Once the nouvelle théologie took firm root within the congregation's collective belief system, however, they were primed for extensive change in their way of life and their work. 
How could it be otherwise? The particular way of life pursued by Catholic women religious for centuries - strict and literal adherence to vows of poverty, chastity, and obedience; full renunciation of the secular world; distinctive habits and veils; devotion to corporate prayer and works of ministry - is based on a system of beliefs about the nature of God and God's relationship to humankind, the authority of the Catholic Church, and what is required of those who desire to serve God and the Church in holiness. As the Sisters of Loretto engaged with the ideas of nouvelle théologie, they experienced a fundamental shift in their belief systems about these basic elements of Catholic Christianity. A corresponding shift in their way of life was the inevitable result. The decrees of Vatican II opened the door for them to enact these changes.

The legacy of Vatican II remains a contested topic among Catholics even in the present day, over half a century after the Council sessions. While many Catholics embraced celebrating Mass in English and the new emphasis on personal scriptural study, and supported the changes in Sisters' appearance and way of life, other Catholics - both laypeople and clergy - opposed some or all of these decisions. They accused the Sisters of misinterpreting the directives of the Council and abandoning their ministries. ${ }^{342}$ The Sisters of Loretto were initially spared some of the worst of such opposition: as an institute of pontifical right, they did not need to seek approval from the local bishop before enacting the changes the community agreed upon, but had to submit their rewritten constitution to the Vatican for final approval.

\footnotetext{
${ }^{342}$ The work of Catholic journalist Ann Carey presents an interesting example of this viewpoint. See Carey's Sisters in Crisis Revisited (San Francisco, CA: Ignatius Press, 2013), an update to her original 1997 publication. Notably, Carey dedicates the book to "...my teachers, the Sisters of Loretto and the Sisters of St. Joseph."
} 
Loretto lent support to other congregations facing difficult decisions, however. Mary Luke Tobin, Superior General of the Sisters of Loretto, was then also serving as President of the Conference of Major Superiors of Women (later the Leadership Conference of Women Religious), American nuns' national cooperative leadership body. In these public capacities, Tobin spoke out in support of the Sisters, Servants of the Immaculate Heart of Mary (IHM) of Los Angeles, as they faced intense opposition from Cardinal James Francis McIntyre, the Archbishop of Los Angeles, over their experimentation and proposed rule changes, begun as early as $1963 .{ }^{343}$

Of course, some other more conservative congregations believed their fellow women religious were acting in error as they began working outside their traditional fields of ministry, renting apartments, and wearing contemporary clothing. These groups chose not to enact such far-reaching changes to their ways of life after the Council, preferring to retain their traditional habits, disciplined schedule of corporate prayer, shared apostolate, and communal life in a convent setting, all of which they deem to be essential elements of consecrated religious life. The dichotomy between these traditionally conservative orders and more progressive communities like the Sisters of Loretto resulted in a rift within the Conference of Major Superiors of Women (CMSW), re-named the Leadership Conference of Women Religious (LCWR) in 1970. A small group of more conservative religious orders, whose leaders expressed discomfort with the direction taken by the LCWR, eventually established an alternate organization, the Conference of Major Superiors of Women Religious (CMSWR), receiving final papal

${ }^{343}$ Anita M. Caspary, Witness to Integrity: The Crisis of the Immaculate Heart Community of California (Collegeville, MN: The Liturgical Press, 2003), 172. 
approval in $1995 .{ }^{344}$ More recently, the LCWR endured a years-long investigation by the Vatican Congregation for the Doctrine of the Faith (CDF), who examined their public statements, conference speakers, and published resource materials, alleging problematic theological positions, in disobedience to Church teaching on a variety of subjects. ${ }^{345}$ Though LCWR leadership later described this process as a "crisis," they also described it as "transformational." ${ }^{346}$ After much discussion and debate, the CDF and LCWR reached a mutual agreement in $2015 .^{347}$

In spite of opposition from parishioners, clergy, and other women religious, the Sisters of Loretto and other progressive orders have persevered in the changes to their way of life enacted following Vatican II. For some congregations, such as the IHM Sisters, as well as the Glenmary Sisters of Cincinnati, who faced intense clerical opposition to their renewal efforts, this meant actually seeking dispensation from their formal vows to pursue their vision for consecrated life, by establishing non-canonical

\footnotetext{
${ }^{344}$ Monica Clark, "Two groups, two paths, for U.S. women religious," National Catholic Reporter, May 26, 2012. https://www.ncronline.org/news/global-sisters-report/twogroups-two-paths-us-women-religious.

${ }^{345}$ See "Doctrinal Assessment of the Leadership Conference of Women Religious," Congregation for the Doctrine of the Faith, http://www.vatican.va/roman curia/congregations/cfaith/documents/rc con_cfaith doc 2 0120418 assessment-lcwr en.html.

346 Annemarie Sanders, IHM, ed. However Long the Night: Making Meaning in a Time of Crisis, A Spiritual Journey of the Leadership Conference of Women Religious (LCWR). (Silver Spring, MD: Leadership Conference of Women Religious, 2018), Kindle edition, location 203- 214.

347 "Vatican completes doctrinal assessment of Leadership Conference of Women Religious," Catholic Culture, April 26, 2015, https://www.catholicculture.org/news/headlines/index.cfm?storyid=24640.
} 
communities, or "secular institutes," outside of direct Church control. ${ }^{348}$ The Sisters of Loretto, though enduring their share of conflict with Church officials, as recently as 2016 , have managed to retain their canonical status while also remaining true to their renewed mission and way of life. ${ }^{349}$

Sister Mary Luke Tobin, as we have noted, played a key role in leading both the Sisters of Loretto and the CMSW (later LCWR) during the Vatican Council as well as the immediate post-conciliar period. It is interesting to note that both of these organizations have so far managed to weather the storms of ecclesiastical opposition. Where some others fared less well, Loretto and the LCWR remain viable organizations in the present, with their relationship to Rome still officially intact. During the critical years of the 1960s, Tobin was uniquely positioned to help guide and advocate for U.S. Catholic Sisters as they interpreted the Council's directives on renewal of religious life. Her personal interest in the nouvelle théologie, which influenced the drafting of the Council documents, as well as her extensive contacts among influential clergy and theologians,

\footnotetext{
${ }^{348}$ For more information on the Glenmary Sisters of Cincinnati, see Helen Lewis and Monica Appleby, Mountain Sisters: From Convent to Community in Appalachia (Lexington, KY: University Press of Kentucky, 2003).

For more on the IHM Sisters, see Anita M. Caspary, Witness to Integrity: The Crisis of the Immaculate Heart Community of California (Collegeville, MN: Liturgical Press, 2003).

${ }^{349}$ From 2008 - 2014, all U.S. communities of women religious were subject to an apostolic "visitation," or official inquiry, into their ways of life, spiritual practices, etc. Two years after this investigation closed, Sister Pearl McGivney, then President of the Loretto Community, was summoned to Rome to "'report on some areas of concern," based on information gathered during the visitation. For more information, see Joshua J. McElwee, "Loretto sisters summoned to Rome, raising questions on closure of apostolic visitation," Global Sisters Report, June 9, 2016. Accessed July 30, 2020, https://www.globalsistersreport.org/news/trends/loretto-sisters-summoned-rome-raisingquestions-closure-apostolic-visitation-40306.
} 
helped her to navigate the turbulent landscape of the post-Conciliar years, providing needed stability and vision to the Loretto Congregation and to the CMSW.

The lives of many women religious today look quite different than they did prior to Vatican II. While some lament these changes and worry that religious life may be facing extinction, others believe that it is simply evolving, as it has done throughout its two millennia of history. Loretto Sister Maureen Fiedler expressed this point of view in a 2013 op-ed for the National Catholic Reporter. Fiedler cited the recent rapid growth of co-membership in the Loretto Community as evidence that many individuals are still drawn to a form of "committed life," sharing mission, values, and spirituality with a group of like-minded people. ${ }^{350}$ Certainly, the work of the Loretto Sisters - and now Loretto co-members - is no less essential than it was when Maureen O'Connell and Eleanor Craig entered the order in the early 1960s. While the Sisters may no longer teach traditional subjects in Catholic school classrooms, the wider Loretto Community's ongoing efforts to effect peace and social justice are a living lesson in the Biblical accounts of the ministry of Jesus Christ. As they have throughout their history, Loretto Sisters, and more recently co-members, continue to act decisively to meet the needs they encounter, and to adapt themselves and their work to a rapidly changing world. The concepts of nouvelle théologie continue to inform Loretto ministries, and while the Congregation's future is unclear, it seems certain they will remain open to "the call of the Gospel" as their understanding of it evolves with the needs of the times.

\footnotetext{
${ }^{350}$ Maureen Fiedler, "The Evolution of the Committed Life in the $21{ }^{\text {st }}$ Century," National Catholic Reporter, June 8, 2013. Accessed July 30, 2020, https://www.ncronline.org/news/global-sisters-report/evolution-committed-life-21stcentury.
} 


\section{REFERENCES}

Ardoyno, Sandy SL and Dianne Dignam Chowen, Marion Golden Curtis, Jackie Hartman Dear, Barbara Speas Havira, Sharon Kassing SL, Michele Minnis, Marion Veeneman Panyan CoL, and Janie Peckham Stoever, eds. Voices from Silence: A Loretto Patchwork. Nerinx, KY: Sisters of Loretto, 2012.

Beane, Marjorie Noterman. From Framework to Freedom: A History of the Sister Formation Conference. Lanham, MD: University Press of America, 1993.

Boersma, Hans. Nouvelle Théologie and Sacramental Ontology: A Return to Mystery. New York: Oxford University Press, 2009. Kindle edition.

Bradbury, Nicholas. The Pastoral Theology of Pierre-André Liégé: a Critical and Comparative Study in Pastoral and Practical Theology. PhD diss., University of Cardiff, 2007. Accessed November 1, 2016, http://orca.cf.ac.uk/55675/1/U584194.pdf.

Brandt, Alex. "St. Louis nun relives Civil Rights march," The Webster Journal, February 16, 2011. Accessed July 20, 2020, http://websterjournal.com/2011/02/16/st-louisnun- relives-civil-rights-march/.

Braude, Anne. Sisters and Saints: Women and American Religion. Oxford, UK: Oxford University Press, 2008.

Bruyn, Severyn T. The Field of Social Investment. Cambridge, UK: Cambridge University Press, 1987.

https://books.google.com/books?id=TuHG8m5zN50C\&pg=PA33\&lpg=PA33\&d $\mathrm{q}=$ Sisters + of + Loretto + sue + Blue + Diamond + Mines\&source $=b l \& o t s=x 5$ VfRYn63 R\&sig=ACfU3U2orVBWXliptOWLyTeIR4rwqZv8mA\&hl=en\&sa=X\&ved $=2 \mathrm{ah}$ UKEwir4uDfwtbnAhXPGM0KHVS7DA4Q6AEwA3oECAoQAQ\#v=onepage\& $\mathrm{q}=$ Sisters $\% 20$ of $\% 20$ Loretto $\% 20$ sue $\% 20$ Blue $\% 20$ Diamond $\% 20$ Mines \&f $=$ false. 
Carey, Ann. Sisters in Crisis Revisited. San Francisco, CA: Ignatius Press, 2013.

Caspary, Anita M., IHM. Witness to Integrity: The Crisis of the Immaculate Heart Community. Collegeville, MN: Liturgical Press, 2003.

Catholic Essentials. "Christian Education," accessed April 4, 2016. http://www.catholicessentials.net/index.htm.

Catholic Culture. "Vatican completes doctrinal assessment of Leadership Conference of Women Religious," April 26, 2015. https://www.catholicculture.org/news/headlines/index.cfm?storyid=24640.

Clark, Monica. "Two groups, two paths, for U.S. women religious," National Catholic Reporter, May 26, 2012. https://www.ncronline.org/news/global-sistersreport/two-groups-two-paths-us-women-religious.

Coburn, Carol. "Ahead of its Time...Or, Right on Time? The Role of the Sister Formation Conference for American Women Religious," American Catholic Studies 126, no. 3 (Fall 2015): 25-44. Accessed April 19, 2020

Coburn, Carol K. and Martha Smith. Spirited Lives: How Nuns Shaped Catholic Culture and American Life, 1836-1920. Chapel Hill: University of North Carolina Press, 1999.

Curran, Charles. "Bernard Häring: a moral theologian whose soul matched his scholarship," National Catholic Reporter, July 17, 1998. http://natcath.org/NCR_Online/archives2/1998c/071798/071898h.htm.

Curran, Charles E. Catholic Social Teaching 1891 - Present: A Historical, Theological, and Ethical Analysis. Washington, D.C.: Georgetown University Press, 2002.

Curran, Charles. "Take and Read: The Law of Christ," National Catholic Reporter, February 1, 2016. https://www.ncronline.org/blogs/ncr-today/take-and-read-lawchrist.

Daigler, Mary Jeremy. Incompatible With God's Design: A History of the Women's Ordination Movement. Lanham, MD: Rowman \& Littlefield Publishing Group, 2012.

Dart, Ron. “Thomas Merton and Nouvelle Théologie," Clarion Journal of Spirituality 
and Justice, July 4, 2011.

http://www.clarion-journal.com/clarion_journal_of_spirit/2011/07/thomasmerton-and-nouvelle-theologie-by-ron-dart.html.

Domenach, Jean-Marie and Robert de Montvalon. The Catholic Avant-Garde: French Catholicism Since World War II. Translated by Brigid Elson, Jacqueline Pace, Irene Uribe, and France Wilms. New York: Holt, Rinehart and Winston, 1967.

Dries, Angelyn. "Living in Ambiguity: A Paradigm Shift Experienced by the Sister Formation Movement." The Catholic Historical Review 79, no. 3 (July 1993): 478-487. Accessed April 10, 2016, http://www.jstor.org/stable/25024073.

Dries, Angelyn. The Missionary Movement in American Catholic History. Ossining, NY: Orbis Books, 1998.

Dulle, Colleen. "If St. Louis is 'the new Selma,' what role will Catholics play in racial reconciliation?" America Magazine - The Jesuit Review, October 3, 2017. Accessed July 20, 2020, https://www.americamagazine.org/politicssociety/2017/10/03/if-st-louis-new-selma-what-role-will-catholics-play-racial.

Dunbar, Carolyn. "On the Road to Jubilee 2012: Loretto moves west from 1830 to 1900 , Founding 99 schools in territories that were soon to become 13 individual states," Loretto Magazine, Summer 2010, 16-18. Accessed April 12, 2016, http://www.lorettocommunity.org/wp-content/uploads/2011/04/Jubilee-1830-to1900.pdf.

Dunbar, Carolyn. "On the Road to Jubilee 2012: From 1900 to 1960...Loretto schools flourish; Colleges leave lasting legacy," Loretto Magazine, Summer 2010: 8-10. Accessed April 12, 2016, http://www.lorettocommunity.org/wpcontent/uploads/2011/04/Jubilee-1900-to-1960-smaller.pdf.

Ebaugh, Helen Rose. "Patriarchal Bargains and Latent Avenues of Social Mobility: Nuns in the Roman Catholic Church," Gender and Society 7, no. 3 (September 1993): 400-414. Accessed August 29, 2016, http://www.jstor.org/stable/189800.

Paulist Fathers. "Father Thomas Stransky." https://www.paulist.org/who-we-are/leadership/fr-thomas-stransky/.

Fialka, John. Sisters: Catholic Nuns and the Making of America. New York: St. Martin's Press, 2003. 
Fiedler, Maureen. "The Evolution of the Committed Life in the $21^{\text {st }}$ Century," National Catholic Reporter, June 8, 2013. Accessed July 30, 2020, https://www.ncronline.org/news/global-sisters-report/evolution-committed-life21st-century.

Flynn, Gabriel and Paul D. Murray, ed. Ressourcement: A Movement for Renewal in Twentieth Century Catholic Theology. Oxford, UK: Oxford University Press, 2012.

Franklin, Ben A. "Nuns Sue to Force 'Accountability' on Coal Company," New York Times, September 20, 1979. https://www.nytimes.com/1979/09/20/archives/nunssue-to-force-accountability-on-coal-company.html.

"Frequently Requested Church Statistics," Center for Applied Research in the Apostolate, Georgetown University. Accessed July 27, 2020, https://cara.georgetown.edu/frequently-requested-church-statistics/.

Garrigou-LaGrange, Fr. Reginald, O.P. "Where is the new theology leading us?" Translated By Suzanne M. Rini. Reprint from Catholic Family News 309 (August 1998). Accessed April 19, 2016, https://archive.org/stream/GarrigouLagrangeEnglish/_Where\%20is\%20the\%20New\%20Theology\%20Leading\%20U s_\%20-\%20Garrigou-Lagrange $\% 2 \mathrm{C} \% 20$ Reginald $\% 2 \mathrm{C} \% 20 \mathrm{O} . \mathrm{P}$ _djuu.txt

Glisky, Joan IHM. "Sister Mary Emil Penet, I.H.M: Founder of the Sister Formation Conference." Catholic Education 9, no. 3 (March 2006): 360-376.

Grim, John and Mary Evelyn Tucker. "Biography," American Teilhard Association. Accessed August 3, 2016, http://teilharddechardin.org/index.php/biography.

Grummett, David. "Teilhard at Ore Place, Hastings," New Blackfriars 90, no. 1030 (November 2009): 692. Accessed August 3, 2016, http://www.jstor.org/stable/43251348.

Halbach, Matt. "New Pope, New Evangelization, New Return to Old (but Good) Ideas," Catechetical Leader 24, no. 5 (September 2013): 19. Accessed October 25, 2016, http://www.21stcenturycatholicevangelization.org/uploads/5/1/6/4/5164069/new pope new evangelization.pdf.

Horan, Michael P. “Josef Jungmann,” Talbot School of Theology at Biola University. 
Accessed October 4, 2016, http://www.talbot.edu/ce20/educators/catholic/josef_jungmann/.

“Jacques Maritain.” Stanford Encyclopedia of Philosophy. Accessed October 30, 2016, http://plato.stanford.edu/entries/maritain/.

Jodock, Darrell, ed. Catholicism Contending with Modernity: Roman Catholic Modernism And Anti-Modernism in Historical Context. Cambridge, UK: Cambridge University Press, 2000.

Jordan, Kathleen De Sutter. "At the Foot of the Cross: Remembering Ann Manganaro," Commonweal, August 30, 2016, https://www.commonwealmagazine.org/footcross.

Kerr, Fergus. Twentieth Century Catholic Theologians. Malden, MA: Blackwell Publishing, 2007.

K'Meyer, Tracy. Civil Rights in the Gateway to the South: Louisville, Kentucky, 19451980. Lexington, KY: University Press of Kentucky, 2009.

Koehlinger, Amy. The New Nuns: Racial Justice and Religious Reform in the 1960s. Cambridge, MA and London: Harvard University Press, 2007.

Kuhns, Elizabeth. The Habit: A History of the Clothing of Catholic Nuns. New York: Doubleday, 2003.

Lewis, Helen, and Monica Appleby. Mountain Sisters: From Convent to Community in Appalachia. Lexington, KY: University Press of Kentucky, 2003.

Lipka, Michael. "U.S. Nuns face shrinking numbers and tensions with the Vatican," Fact Tank, August 8, 2014. http://www.pewresearch.org/fact-tank/2014/08/08/u-snuns-face-shrinking-numbers-and-tensions-with-the-vatican/.

Loretto Jubilee Oral History Collection, Kentucky Historical Society, Frankfort, KY.

Maes, Rev. Camillus P. The Life of Rev. Charles Nerincx: With a Chapter on the Early Catholic Missions of Kentucky; Copious Notes on the Progress of Catholicity in The United States of America from 1800 to 1825; An Account of the Establishment of the Society of Jesus in Missouri; and an Historical Sketch of the 
Sisterhood of Loretto in entucky, Missouri, New Mexico, etc.Cincinnati: Robert Clarke and Company, 1880.

https://books.google.com/books?id=5lwAAAAAMAAJ\&printsec=frontcover\&so urce $=$ gbs_ge_summary_r\&cad $=0 \# \mathrm{v}=$ onepage $\& \mathrm{q} \& \mathrm{f}=$ false.

Manion, Patricia Jean SL, ed. A Century of Change 1912-2012: Loretto's Second Century. Point Reyes Station, CA: Chardon Press, 2012.

O'Daniel, Hannah. "Southern Veils: The Sisters of Loretto in Early National Kentucky.” M.A. Thesis, University of Louisville, 2017.

McCauley, Bernadette. "Nuns' Stories: Writing the History of Women Religious in the United States," American Catholic Studies 125, no. 4 (Winter 2014): 51-68. Accessed May10, 2020, https://doi.org/10.1353/acs.2014.0067.

McElwee, Joshua J. "Loretto sisters summoned to Rome, raising questions on closure of apostolic vistitation." Global Sisters Report, June 9, 2016. https://www.globalsistersreport.org/news/trends/loretto-sisters-summoned-romeraising-questions-closure-apostolic-visitation-40306.

McGuinness, Margaret. Called to Serve: A History of Nuns in America. New York and London: New York University Press, 2013.

McNamara, Jo Ann Kay. Sisters in Arms: Catholic Nuns Through Two Millennia. Cambridge, MA: Harvard University Press, 1996.

Mettepenningen, Jurgen. Nouvelle Théologie - New Theology: Inheritor of Modernism, Precursor of Vatican II. London: T\&T Clark International, 2010.

Meyers, Bertrande DC. The Education of Sisters. New York: Sheed and Ward, 1941. http://babel.hathitrust.org/cgi/pt?id=uc1.\$b55048;view=1up;seq=7.

Minogue, Anna. Loretto Annals of the Century. New York: The American Press, 1913. https://archive.org/stream/lorettoannalsce01minogoog\#page/n49/mode/2up.

Mulderry, Dara. 'Educating 'Sister Lucy:' The Experiential Sources of the Movement to Improve Higher Education for Catholic Teaching Sisters, 1949-1964." U.S. Catholic Historian 33, no. 1 (Winter 2015): 55-79. Accessed May 10, 2020, https://doi.org/10.1353/cht.2015.0006. 
Mulderry, Dara. "People Are Suffering; People are Christ, and We Are Responsible": Sister Mary Emil Penet's Campaign for Social-Justice Education in the 1950s." The Catholic Historical Review 103, no. 4 (Autumn 2017): 725-754. Accessed May 10, 2020, https://doi.org/10.1353/cat.2017.0161.

Mulderry, Dara. “'What Human Goodness Entails': An Intellectual History of U.S. Catholic Sisters, 1930-1980.” PhD diss., Brandeis University, 2006.

"National Advisory Board," Leadership, Women's Ordination Conference, accessed February 16, 2020, https://www.womensordination.org/leadership/.

O’Malley, John W. What Happened at Vatican II. Cambridge, MA: Harvard University Press, 2008.

"Perfectae Caritatis," Vatican Archives, accessed February 17, 2020, http://www.vatican.va/archive/hist councils/ii_vatican council/documents/vatii_decree_19651028_perfectae-caritatis_en.html.

Petit, M. Loretta, OP. “Sister M. Madaleva Wolff, C.S.C.” Catholic Education 9, no. 3 (March 2006) 320-333.

"Pontifical Academy of St. Thomas Aquinas." The Vatican, accessed May 19, 2016, http://www.vatican.va/roman_curia/pontifical_academies/santommaso/index.htm.

Quiñonez, Lora Ann, and Mary Daniel Turner. The Transformation of American Catholic Sisters. Philadelphia: Temple University Press, 1992.

Rapley, Elizabeth. The Lord as Their Portion: The Story of the Religious Orders and How They Shaped Our World. Grand Rapids, MI: Wm. B. Eerdmans Publishing Co., 2011.

Reese, Abbie. Dedicated to God: An Oral History of Cloistered Nuns. Oxford, UK: Oxford University Press, 2014.

Robert, Dana L. American Women in Mission: A Social History of Their Thought and Practice. Macon, GA: Mercer University Press, 1997.

Rogers, Carol Garibaldi. Habits of Change: An Oral History of American Nuns. Oxford, UK: Oxford University Press, 2011. 
Sadowsky, Dennis. "Father Thomas Stransky had key role in ecumenical, interreligious work," Crux, September 9, 2019. https://cruxnow.com/obituary/2019/09/fatherthomas-stransky-had-key-role-in-ecumenical-interreligious-work/.

Sanders, Annemarie, IHM, ed. However Long the Night: Making Meaning in a Time of Crisis, A Spiritual Journey of the Leadership Conference of Women Religious (LCWR). Silver Spring, MD: Leadership Conference of Women Religious, 2018.

Sanders, Helen SL. More Than A Renewal. Loretto Before and After Vatican II: 19521977. Nerinx, KY: Sisters of Loretto, 1982.

Schneider, Mary L. "American Sisters and the Roots of Change: the 1950s." U.S. Catholic Historian 7, no.1 (Winter 1988): 55-72. Accessed April 10, 2016. http://www.jstor.org/stable/25153816.

Senior, Donald, C.P. "Caroll Stuhlmueller, C.P.: The Life and Scholarship of an Immortal Teacher," U.S. Catholic Historian 31, no. 4 (Fall 2013). Accessed October 19, 2016, http://muse.jhu.edu/article/539970.

Sinclair, Ward and Bill Bishop. "Justice Moves Slowly in Mine Disaster," Washington Post, March 9, 1980. https://www.washingtonpost.com/archive/politics/1980/03/09/justice-movesslowly-in-mine-disaster/7b586840-d171-4780-98f6-b5d8acc6059f/.

Stewart, George C. Marvels in Charity: History of American Sisters and Nuns. Huntington, IN: Our Sunday Visitor, 1994.

Sister-students' Correspondence from Europe, 1959-1963. Loretto Archives, Loretto Motherhouse, Nerinx, KY.

Taylor, Sarah McFarland. Green Sisters: A Spiritual Ecology. Cambridge, MA and London: Harvard University Press, 2007.

The Catechism of the Catholic Church. "The Liturgy of the Hours," accessed April 13, 2016, http://www.vatican.va/archive/ENG0015/_P39.HTM.

The Vatican. "Code of Canon Law." Accessed September 2, 2016, http://www.vatican.va/archive/ENG1104/_P1Y.HTM. 
The Vatican. "The Congregation for Institutes of Religious Life and Societies of Apostolic Life." Accessed September 8, 2016, http://www.vatican.va/roman_curia/congregations/ccscrlife/documents/rc con cc scrlife_profile_en.html.

The Vatican, “"'Doctrinal Assessment of the Leadership Conference of Women Religious," Accessed June 15, 2020, http://www.vatican.va/roman_curia/congregations/cfaith/documents/rc con_cfait h doc 20120418 assessment-lcwr en.html.

Thurston, Bonnie and Mary Swain SL, ed. Hidden in the Same Mystery: Merton and Loretto. Louisville, KY: Fons Vitae, 2010.

Tobin, Mary Luke SL. "Female and Catholic: An Interview with Sister Mary Luke Tobin, S.L.," U.S. Catholic, April 1987. https://www.uscatholic.org/church/2012/09/female-and-catholic-interview-sistermary-luke-tobin-sl.

Tobin, Mary Luke SL. Hope is an Open Door. Nashville: Abingdon, 1981.

Tobin, Mary Luke SL. "Women in the Church Since Vatican II," America Magazine, November 1, 1986. https://www.americamagazine.org/issue/100/women-churchvatican-ii.

Ware, Ann Patrick SL, ed. Midwives of the Future: American Sisters Tell Their Stories. Kansas City, MO: Leaven Press, 1985.

Ware, Ann Patrick SL, ed. Naming Our Truth: Stories of Loretto Women. Inverness, CA: Chardon Press, 1995.

Wayne, Jim. "Had Catholics lived their faith and not been racist, Louisville might be very different today," Louisville Courier-Journal, July 1, 2020, accessed July 16, 2020, https://www.courier-journal.com/story/opinion/2020/07/01/catholics-racismflight-west-end-helped-segregate-louisville/5348572002/.

"What is Divine Office," Divine Office Ministry, accessed February 17, 2020, https://divineoffice.org/liturgy-of-the-hours/.

"What is the SOA?" SOA Watch, accessed November 14, 2015, http://www.soaw.org/about-the-soawhinsec/what-is-the-soawhinsec.. 
Women's Ordination Conference. “About Us: About Our Work.” Accessed February 18, 2020. https://www.womensordination.org/about-us-import/about-our-work/. 


\section{CURRICULUM VITAE}

NAME: $\quad$ Carol Bolton Easterly

ADDRESS: 112 Pickett Avenue

Frankfort, KY 40601

DOB: $\quad$ Louisville, KY - February 2, 1980

EDUCATION

\& TRAINING: $\quad$ B.A., History

Anderson University (SC)

$1998-2002$

M.A., History (Public/U.S.)

University of Louisville

$2014-2020$

Archival Intern

Loretto Motherhouse

Nerinx, KY

Summer 2015

Collections Intern

The Kentucky Derby Museum

Louisville, KY

Spring 2016

PROFESSIONAL

EXPERIENCE: Museum Specialist

Louisville WaterWorks Museum

Louisville, KY

$2015-2017$

Education Interim

Kentucky Historical Society

Frankfort, KY 


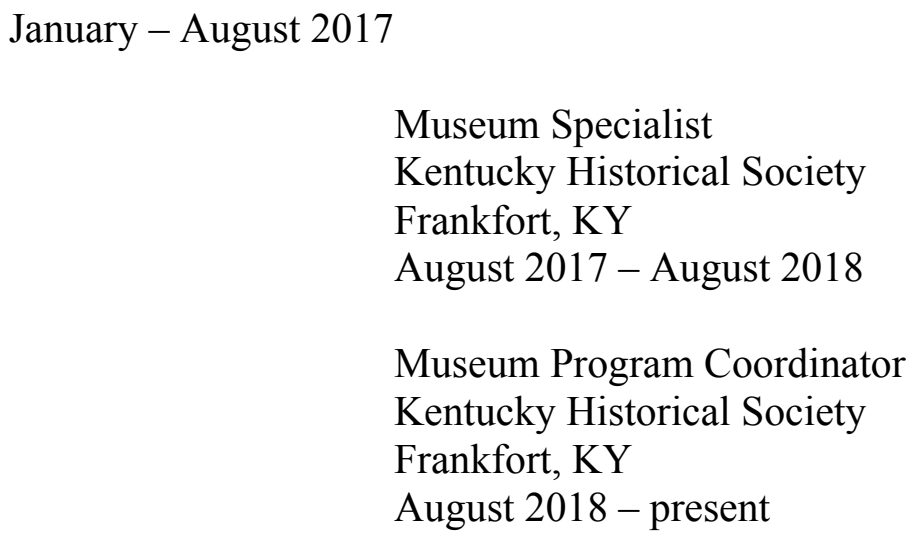

Museum Specialist

Kentucky Historical Society

Frankfort, KY

August 2017 - August 2018

Museum Program Coordinator

Kentucky Historical Society

Frankfort, KY

August 2018 - present

PROFESSIONAL SOCIETIES: National Council on Public History

Southeastern Museums Conference

American Association for State and Local History 